CAMILA GREICE CHRIST

EFEITO DO GQ-02, DERIVADO DE TIAZOLIDINADIONAS, SOBRE A AQUISIÇÃO DE FENÓTIPO TERMOGÊNICO PELO ADIPÓCITO IN VIVO E EM CULTURA DE CÉLULAS

BRASÍLIA 


\author{
UNIVERSIDADE DE BRASÍLIA \\ FACULDADE DE CIÊNCIAS DA SAÚDE \\ PROGRAMA DE PÓS-GRADUAÇÃO EM CIÊNCIAS DA SAÚDE
}

CAMILA GREICE CHRIST

EFEITO DO GQ-02, DERIVADO DE TIAZOLIDINADIONAS, SOBRE A AQUISIÇÃO DE FENÓTIPO TERMOGÊNICO PELO ADIPÓCITO IN VIVO E EM CULTURA DE CÉLULAS

Dissertação apresentada como requisito parcial à obtenção do Título de Mestre em Ciências da Saúde pelo Programa de Pós-Graduação em Ciências da Saúde da Universidade de Brasília.

Orientadora: Prof ${ }^{a}$ Angélica Amorim Amato Co-orientadora: Prof ${ }^{\underline{a}}$ Michella Soares Coêlho

BRASÍLIA 


\section{EFEITO DO GQ-02, DERIVADO DE TIAZOLIDINADIONAS, SOBRE A AQUISIÇÃO DE FENÓTIPO TERMOGÊNICO PELO ADIPÓCITO IN VIVOE EM CULTURA DE CÉLULAS}

Dissertação apresentada como requisito parcial à obtenção do Título de Mestre em Ciências da Saúde pelo Programa de Pós-Graduação em Ciências da Saúde da Universidade de Brasília.

Aprovado em 04 de março de 2016

BANCA EXAMINADORA

Angélica Amorim Amato

Universidade de Brasília

Patrícia de Oliveira Prada

UNICAMP

Francisco de Assis Rocha Neves

Universidade de Brasília

Carine Royer

Universidade de Brasília 
Aos meus pais, Licério e Maria de Lurdes, por sempre me darem motivação e apoio incondicional para alcançar meus sonhos

À minha irmã, Karina, pela cumplicidade, carinho e por ser meu exemplo de dedicação 


\section{AGRADECIMENTOS}

Aos meus pais, Licério Alípio Christ e Maria de Lurdes Christ, e à minha irmã, Karina Bianca Christ, por serem os meus maiores exemplos de força e determinação, pelo exemplo de família e de união e por todo o apoio, minha eterna gratidão.

Ao meu namorado, Thiago Brandão, por percorrer esta trajetória junto comigo. Pelo companheirismo e compreensão nos momentos difíceis e pelo incentivo para realizar sempre o meu melhor, trazendo sorrisos e sonhos aos meus dias.

À Prof ${ }^{a}$ Angélica Amato, minha orientadora, toda a minha admiração e respeito. Um exemplo de doçura, competência e profissionalismo que levarei como ensinamentos para toda a vida. Pelo incentivo à pesquisa e por nos fazer confiar sempre em nós mesmos. À Prof ${ }^{a}$ Michella Soares, pela dedicação a mim dispensada e por todos os ensinamentos com o modelo animal. Ao Profo Francisco, pelo apoio ao projeto, por sempre acreditar na pesquisa e nos incentivar a continuar procurando as respostas.

Aos professores, Adriana Lofrano, Carine Royer, Djane Duarte, Guilherme Santos, Luiz Simeoni, Marília Barros, Maria de Fátima Borin e Marie Togashi, pela assistência em meu projeto e colaboração dedicada aos projetos desenvolvidos pelo Laboratório de Farmacologia Molecular da UnB.

Às amigas, Simone e Wanessa, pelo apoio em diversas situações e pelos momentos de amizade, são pessoas iluminadas que permanecerão em minha vida para sempre. Às amigas, Larissa e Isabela, pela amizade mantida por anos e por todas as mensagens de apoio e carinho.

Ao grupo da professora Angélica, pela receptividade que me receberam. À Fernanda, pelo companheirismo com o modelo animal nos dias de tratamento e por toda a ajuda a mim dedicada, exemplo de simpatia e serenidade. À Bruna e Janice, pelos conselhos, conversas e todo apoio.

À Flora, pelos ensinamentos com a cultura celular e pelas oportunidades a mim oferecidas. À Cinthia, Anna Paula, Sidney, Henrique, Carol Lourenço, Carol Martins, Nadyellem, Bel, Érica, Mariella, Nathália, Pedro, Laíza, Dani, Ádria, Sônia e 
Martha, pelos momentos de descontração, pelos ensinamento no convívio diário e ajuda.

Aos meus PIBICs, Ana Carolina e Paulo, pela ajuda no projeto e pelos questionamentos que me faziam encontrar as respostas.

Aos estagiários, Mariana, Hanna, Isadora, Paloma, Nero, Klíssia e Yasmin, pela ajuda e pela disponibilidade que nos dedicam.

À Rilva, Glorinha, Cristina e Luciano, pela colaboração constante; e aos técnicos do biotério, especialmente ao Emiraldo, pelo apoio essencial com os cuidados aos animais. 
O relógio está correndo

Aproveite o máximo de hoje

O tempo não espera nenhum homem

O ontem é história

O amanhã é um mistério

Mas o hoje é uma dádiva,

É por isso que se chama presente

Alice Morse Earle 


\section{RESUMO}

A prevalência da obesidade está em ascensão mundial e associa-se ao desenvolvimento de resistência insulínica e diabetes mellitus tipo 2 (DM2). Tiazolidinadionas (TZD) melhoram a sensibilidade à insulina e a homeostase da glicose em humanos e modelos animais. Os efeitos benéficos são, em grande parte, devidos à ativação do receptor gama ativado por proliferadores peroxissomais (PPAR $\gamma$ ). A utilização clínica das TZD, no entanto, é limitada devido a efeitos adversos de ganho ponderal e adipogênese, retenção hídrica, perda de massa óssea e aumento do risco cardiovascular. A ativação parcial e específica do PPAR $\gamma$, assim como a modulação seletiva de sua atividade em determinados tecidos, apresenta capacidade de sensibilização insulínica sem indução de ganho ponderal associado à ativação completa e não seletiva pelas TZD. Ativação total de PPAR pelas TZD está associada também à indução de perfil de expressão gênica relacionado à termogênese no tecido adiposo branco (TAB), aumento da expressão da proteína desacopladora 1 (UCP1) na membrana mitocondrial interna e aumento da biogênese mitocondrial. Estas ações, contudo, não resultam em aumento do gasto energético e redução ponderal. O desenvolvimento de ligantes com atividade agonista parcial/moduladora seletiva e capazes de induzir a termogênese no TAB poderia representar estratégia para tratamento simultâneo da obesidade e resistência insulínica. Com objetivo de investigar o composto derivado de TZD, GQ02, sobre variáveis metabólicas e a expressão de Ucp1 no adipócito branco, foram realizados ensaios em cultura de células e in vivo, com camundongos C57BI/6 alimentados com dieta hiperlipídica (DHL). O GQ-02 apresentou efeito adipogênico fraco em pré-adipócitos 3T3-L1 induzidos a se diferenciar em cultura de células com meio contendo inibidor de fosfodiesterase, dexametasona e insulina. In vivo, o tratamento com GQ-02 (20 mg/kg/dia), durante 21 dias, apresentou efeito antidiabético semelhante ao da TZD clássica rosiglitazona e, ainda, perda de peso e redução da eficiência metabólica nos camundongos alimentados com DHL. Foi observado, ainda, em resposta ao tratamento com GQ-02, redução da massa do tecido adiposo branco visceral e do tamanho dos adipócitos, acompanhado de tendência ao aumento do consumo de oxigênio e aumento significativo da expressão do gene que codifica Ucp1 neste depósito de TAB. No tecido adiposo marrom, foi observado redução do conteúdo lipídico intracelular e tendência ao aumento da expressão de Ucp1 nos camundongos tratados com GQ-02. Não foram observadas diferenças nas características histológicas do TAB subcutâneo e, no fígado, foi observado melhora da esteatose hepática em resposta ao tratamento com o GQ-02. Estes resultados sugerem efeitos metabólicos favoráveis do GQ-02 em modelo de obesidade e DM2, que incluem seu possível potencial termogênico.

Palavras-chave: obesidade, diabetes mellitus tipo 2, receptor gama ativado por proliferadores peroxissomais, tiazolidinadionas, GQ-02, proteína desacopladora 1. 


\begin{abstract}
The prevalence of obesity is on the rise worldwide and is associated with the development of insulin resistance and type 2 diabetes mellitus (T2D). Thiazolidinediones (TZD) enhance insulin sensitivity and glucose homeostasis in humans and animal models. The beneficial effects are largely due to the activation of peroxisome proliferator-activated receptor gamma (PPAR $\gamma$ ). The clinical use of TZDs, however, is limited due to side effects of weight gain and adipogenesis, fluid retention, loss of bone mass and increased cardiovascular risk. The partial and specific activation of PPAR $\gamma$, as well as the selective modulation of its activity in certain tissues, results in improved insulin sensitivity without inducing weight gain associated with the full and non-selective activation by TZDs. Full activation of PPAR $\gamma$ by TZDs is also associated with induction of gene expression profile related to thermogenesis in white adipose tissue (WAT), increased expression of uncoupling protein 1 (UCP1) in the inner mitochondrial membrane and increased mitochondrial biogenesis. These actions, however, do not result in increased energy expenditure and weight loss. The development of PPAR $\gamma$ ligands with partial agonist / selective modulator activity capable of inducing thermogenesis in WAT could represent a strategy for the simultaneous treatment of obesity and insulin resistance. In order to investigate the TZD-derivative compound GQ-02 on metabolic variables and UCP1 expression in white adipocytes, assays were performed in cell culture and in vivo with C57BL/6 mice fed with high fat diet (HFD). GQ-02 showed a weak adipogenic effect on preadipocytes 3T3-L1 induced to differentiate in cell culture medium containing phosphodiesterase inhibitor, dexamethasone, and insulin. In vivo, treatment with GQ02 (20 mg/kg/day) for 21 days showed an antidiabetic effect similar to that of the classical TZD rosiglitazone, in addition to weight loss and decreased metabolic efficiency. GQ-02 treatment also reduced visceral WAT mass and the size of adipocytes, accompanied by a trend torwards increased oxygen consumption and an increased expression of Ucp1 in this fat depot. In brown adipose tissue, there was a decrease in intracellular lipid content and a trend towards increases Ucp1 expression in mice treated with GQ-02. No differences were observed in the histological characteristics of subcutaneous WAT. There was an improvement of hepatic steatosis in response to treatment with GQ-02. These results suggest the favorable metabolic effects of GQ-02 in an obesity and T2D model, including its possible potential thermogenic effect.
\end{abstract}

Keywords: obesity, type 2 diabetes mellitus, peroxisome proliferator-activated receptor gamma, thiazolidinedione, GQ-02, uncoupling protein-1. 


\section{LISTA DE FIGURAS}

Figura 1 Expansão saudável e patológica do tecido adiposo.

Figura 2 Características morfológicas do adipócito branco e marrom.

Figura 3 Regulação transcricional do desenvolvimento de adipócitos marrons.

Figura 4 Regulação transcricional do desenvolvimento de adipócitos bege.

Figura 5 Localização anatômica predominante dos adipócitos marrom, branco e bege em camundongos e humanos adultos.

Figura $6 \quad$ Estrutura geral dos receptores nucleares.

Figura $7 \quad$ Estrutura química das TZD clássicas.

Figura 8 Funções da ativação de PPAR $\gamma$ no tecido adiposo.

Figura 9 Modificações pós-traducionais do PPAR $\gamma$.

Figura 10 Estrutura química do composto 5-(4-cloro-benzilideno)-3-(4-metilbenzil)-tiazolidina-2,4-diona (GQ-02).

Figura 11 Efeito do GQ-02 sobre a adipogênese em pré-adipócitos 3T3-L1 induzidos com meio completo.

Figura 12 Efeito do GQ-02 sobre a adipogênese em células mesenquimais C3H10T1/2 induzidas com meio completo.

Figura 13 Efeito do GQ-02 sobre a adipogênese em pré-adipócitos 3T3-L1 induzidos com meio incompleto.

Figura 14 Ganho de peso corporal em camundongos alimentados com DC ou DHL.

Figura 15 Consumo energético e hídrico em camundongos alimentados com DC ou DHL.

Figura 16 Glicemia de jejum em camundongos alimentados com DC ou DHL

Figura 17 Efeito do GQ-02 sobre a glicemia de jejum.

Figura 18 Efeito do GQ-02 sobre o ganho ponderal induzido por DHL.

Figura 19 Efeito do GQ-02 sobre o consumo energético e hídrico.

Figura 20 Efeito do GQ-02 sobre a eficiência metabólica.

Figura 21 Efeito do GQ-02 sobre a massa do tecido adiposo branco visceral epididimal.

Figura 22 Efeito do GQ-02 sobre a massa do tecido adiposo branco subcutâneo inguinal. 
Figura 23 Efeito do GQ-02 sobre a massa do tecido adiposo marrom interescapular.

Figura 24 Efeito do GQ-02 sobre as massas do coração, rins e testículos.

Figura 25 Efeito do GQ-02 sobre o consumo de oxigênio do tecido adiposo branco visceral epididimal.

Figura 26 Efeito do GQ-02 sobre o consumo de oxigênio do tecido adiposo branco subcutâneo inguinal.

Figura 27 Efeito do GQ-02 sobre o consumo de oxigênio do tecido adiposo marrom interescapular.

Figura 28 Efeito do GQ-02 sobre características morfológicas do tecido adiposo branco visceral epididimal.

Figura 29 Efeito do GQ-02 sobre características morfológicas do tecido adiposo branco subcutâneo inguinal.

Figura 30 Efeito do GQ-02 sobre características morfológicas do tecido adiposo marrom interescapular.

Figura 31 Efeito do GQ-02 sobre características morfológicas do fígado.

Figura 32 Efeito do GQ-02 sobre a dosagem de TG hepático.

Figura 33 Efeito do GQ-02 sobre a expressão de RNAm do gene relacionado à termogênese Ucp1. 


\section{LISTA DE QUADROS}

Quadro 1

Classificação de indivíduos adultos segundo o IMC

Quadro 2

Descrição dos componentes das dietas controle e hiperlipídica

Quadro 3

Sequência dos primers utilizados para determinação da

expressão gênica por PCR quantitativa em tempo real 


\section{LISTA DE ABREVIATURAS E SIGLAS}

\begin{tabular}{|c|c|}
\hline AF-1 & - função de ativação 1 \\
\hline AF-2 & - função de ativação 2 \\
\hline AMPc & - adenosina 3', 5' monofosfato cíclico \\
\hline C/EBP & - proteína de ligação ao amplificador CCAAT \\
\hline $\mathrm{C} / \mathrm{EBP} \alpha$ & - proteína alfa de ligação ao amplificador CCAAT \\
\hline C/EBP $\beta$ & - proteína beta de ligação ao amplificador CCAAT \\
\hline C/EBP $\delta$ & - proteína delta de ligação ao amplificador CCAAT \\
\hline Cdk & - cinases dependentes de ciclina \\
\hline Cidea & - gene que codifica o indutor de morte celular \\
\hline DBD & - domínio de ligação ao DNA \\
\hline DC & - dieta controle \\
\hline DEPC & - dietilpirocarbonato \\
\hline DHL & - dieta hiperlipídica \\
\hline DM2 & - diabetes mellitus tipo 2 \\
\hline DMSO & - dimetilsulfóxido \\
\hline DNA & - ácido desoxirribonucleico \\
\hline cDNA & - ácido desoxirribonucleico complementar \\
\hline DNAse & - enzima desoxirribonuclease \\
\hline EPM & - erro padrão da média \\
\hline FABP ou aP2 & - proteína ligadora de ácidos graxos \\
\hline FDA & - Food and Drug Administration \\
\hline TNF- $\alpha$ & - fator de necrose tumoral alfa \\
\hline Gapdh & - gliceraldeído 3-fosfato desidrogenase \\
\hline GQ-02 & $\begin{array}{l}\text {-5-(4-cloro-benzilideno)-3-(4-metil-benzil)-tiazolidina-2,4- } \\
\text { diona }\end{array}$ \\
\hline GQ-16 & $\begin{array}{l}\text { - 5-(5-bromo-2-metoxi-benzilideno)-3-(4-metil-benzil)- } \\
\text { tiazolidina-2,4-diona) }\end{array}$ \\
\hline $\mathrm{H}$ & - a hélice \\
\hline IBMX & - isobutilmetilxantina \\
\hline IL-6 & - interleucina 6 \\
\hline IMC & - índice de massa corporal \\
\hline
\end{tabular}




\begin{tabular}{|c|c|}
\hline LBD & - domínio de ligação ao ligante \\
\hline MAPK & - proteína cinase ativada por mitogênio \\
\hline Myf5+ & - fator miogênico 5 \\
\hline NCoR & - correpressor de receptores nucleares \\
\hline OMS & - Organização Mundial da Saúde \\
\hline PCR & - reação de polimerase em cadeia \\
\hline PET-CT & $\begin{array}{l}\text { - tomografia por emissão de pósitrons combinado com } \\
\text { tomografia computadorizada }\end{array}$ \\
\hline PGC-1 $\alpha$ & $\begin{array}{l}\text { - coativador } 1 \alpha \text { do receptor ativado por proliferadores } \\
\text { peroxissomais gama }\end{array}$ \\
\hline PPAR & - receptor ativado por proliferador peroxissomal \\
\hline PPAR $\alpha$ & - receptor alfa ativado por proliferador peroxissomal \\
\hline PPAR $\gamma$ & - receptor gama ativado por proliferador peroxissomal \\
\hline $\mathrm{PPAR} \beta / \delta$ & - receptor beta/delta ativado por proliferador peroxissomal \\
\hline PRDM16 & - proteína contendo o domínio 16 \\
\hline $\mathrm{RN}$ & - receptor nuclear \\
\hline RNA & - ácido ribonucleico \\
\hline RNAm & - ácido ribonucleico mensageiro \\
\hline RNAt & - ácido ribonucleico total \\
\hline RSG & - rosiglitazona \\
\hline $\mathrm{RXR}$ & - receptor do ácido 9-cis retinóico (retinoid $X$ receptor) \\
\hline SIRT1 & - desacetilase dependente de NAD sirtuína 1 \\
\hline SNC & - sistema nervoso central \\
\hline TAB & - tecido adiposo branco \\
\hline TAM & - tecido adiposo marrom \\
\hline TG & - triglicerídeos \\
\hline TZD & - tiazolidinadiona \\
\hline UCP1 & - proteína desacopladora 1 \\
\hline Ucp1 & - gene que codifica a proteína desacopladora 1 \\
\hline
\end{tabular}




\section{SUMÁRIO}

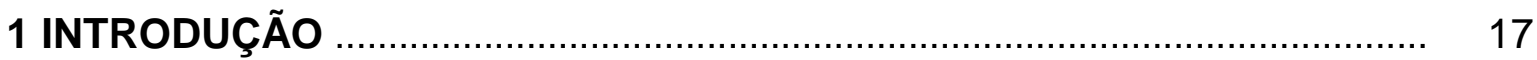

2 REVISÃO BIBLIOGRÁFICA …………………………................................. 20

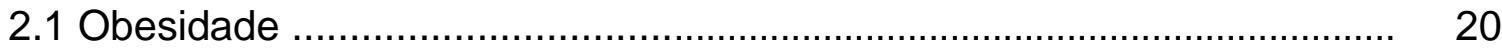

2.1.1 Definição ................................................................................ 20

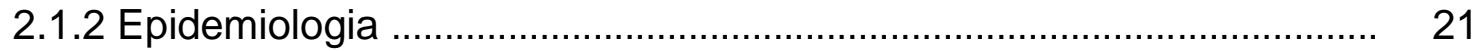

2.1.3 Fisiopatologia da obesidade e correlação com o diabetes mellitus 22 tipo 2

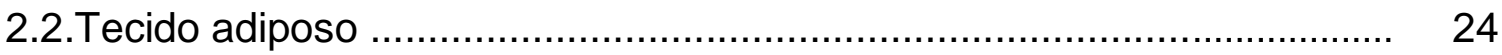

2.2.1 Morfologia ............................................................................ $\quad 25$

2.2.2 Adipócito bege e termogênese adaptativa ………………….............. 26

2.2.3 Distribuição do tecido adiposo ................................................... $\quad 30$

2.2.3.1 Tecido adiposo branco ………………………................... 30

2.2.3.2 Tecido adiposo marrom ..................................................... 31

2.3 Receptores nucleares .................................................................. 32

2.3.1 Ativação dos receptores nucleares ............................................... 34

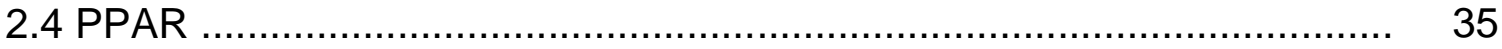

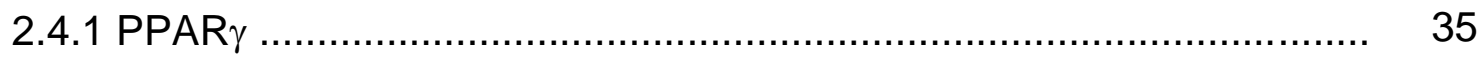

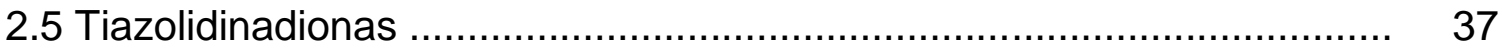

2.5.1 Efeitos metabólicos das TZD ..................................................... 38

2.5.2 Efeitos adversos das TZD ................................................... 40

2.5.3 Ativação de PPAR $\gamma$ por TZD e modulação seletiva .......................... 42

2.5.4 Regulação pós-traducional de PPAR $\gamma$............................................ 44

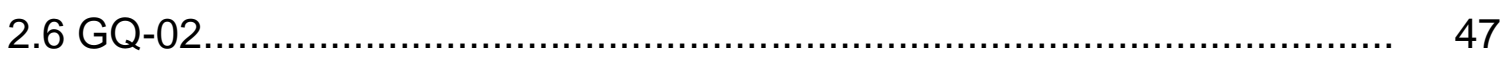

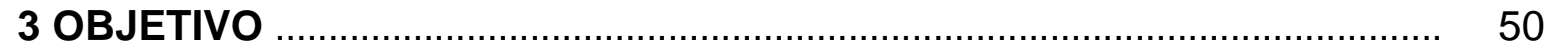

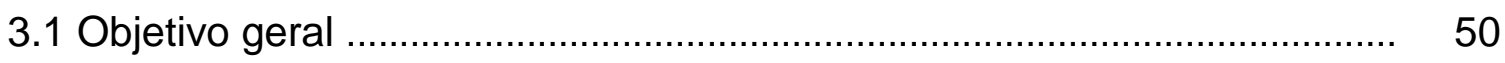

3.2 Objetivos específicos ......................................................................... 50

4 MATERIAL E MÉTODOS …................................................................ 51

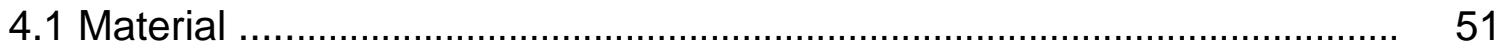


4.2 Cultura de células

4.2.1 Ensaio de adipogênese .......................................................... 51

4.2.2 Coloração com óleo vermelho $\mathrm{O}$.................................................. 53

4.3 Modelo animal ................................................................................. 54

4.3.1 Considerações éticas ........................................................... 54

4.3.2 Delineamento experimental ........................................................ 54

4.3.3 Procedimentos .................................................................. 56

4.4 Ensaio de respiração …………................................................. 57

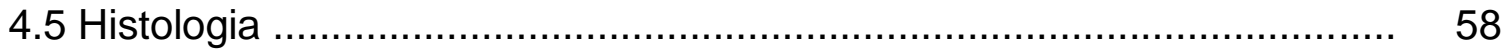

4.5.1 Fixação de tecidos ............................................................... 58

4.5.2 Desidratação e inclusão em parafina ............................................ 58

4.5.3 Corte no micrótomo ….............................................................. 59

4.5.4 Coloração com hematoxilina-eosina ............................................. 60

4.6 Quantificação de triglicerídeos hepáticos ............................................ 61

4.7 Análise da expressão gênica .......................................................... 61

4.7.1 Isolamento de RNA total .................................................... 61

4.7.2 Quantificação do RNA total e determinação da pureza da amostra .. $\quad 62$

4.7.3 Tratamento do RNA com enzima DNAse ........................................ 63

4.7.4 PCR quantitativa em tempo real ................................................ 63

4.8 Análise estatística ..................................................................... 65

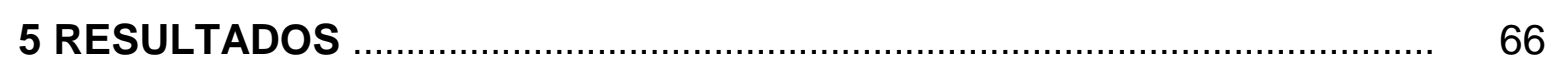

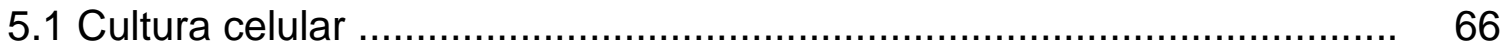

5.1.1 Efeito do GQ-02 sobre a adipogênese .......................................... 66

5.2 Modelo animal ............................................................................ 70

5.2.1 Caracterização do modelo animal ................................................ $\quad 70$

5.2.2 Efeito do GQ-02 sobre a glicemia de jejum ................................... 72

5.2.3 Efeito do GQ-02 sobre o ganho de peso, ingestão energética e 72 hídrica e eficiência metabólica

5.2.4 Efeito do GQ-02 sobre a adiposidade ………............................ $\quad 74$

5.2.5 Efeito do GQ-02 sobre o peso do coração, rins e testículos ............. 76 
5.2.6 Efeito do GQ-02 sobre o consumo de oxigênio

5.2.7 Efeito do GQ-02 sobre características histológicas do tecido 79 adiposo e fígado

5.2.8 Efeito do GQ-02 sobre a dosagem de triglicerídeos

5.3 Expressão gênica

5.3.1 Efeitos do GQ-02 sobre a expressão de gene relacionado à 84 termogênese no tecido adiposo

6 DISCUSSÃO 86

7 CONCLUSÃO 96

REFERÊNCIAS 


\section{INTRODUÇÃO}

Obesidade e sobrepeso são problemas de saúde pública mundial (1). O sobrepeso, em 2014 , abrangia $39 \%$ da população mundial adulta com idade acima de 18 anos e, destes, 13\% estavam obesos (2). No Brasil, a frequência de excesso de peso em adultos acima de 18 anos era de $52,5 \%$, em 2014, enquanto que a de obesos era de $17,9 \%$, sem apresentar diferença entre os sexos (3).

A obesidade resulta de interação complexa entre fatores genéticos, ambientais, comportamentais e metabólicos que afetam o equilíbrio entre a ingestão e o gasto energético (1) , promovendo acúmulo excessivo e prejudicial de gordura corporal (4).

A obesidade está associada com o desenvolvimento de outras doenças, como o diabetes mellitus tipo 2 (DM2), dislipidemia, doença cardíaca coronariana, distúrbios respiratórias, osteoartrose de grandes e pequenas articulações e aumento da incidência de certas formas de câncer (5).

O DM2, uma doença antigamente considerada de início tardio, aumentou acentuadamente entre crianças e jovens simultaneamente ao aumento da obesidade (6). DM2 representa uma desordem metabólica caracterizada por hiperglicemia crônica, resultado de defeitos na ação da insulina, secreção de insulina ou em ambas (7).

A ascensão na prevalência de obesidade e DM2 acarreta crescente investigação no desenvolvimento de terapêuticas eficazes (8). O tecido adiposo, ao atuar como regulador chave da homeostase energética, representa foco de interesse das pesquisas envolvendo obesidade e doenças metabólicas a ela associadas (1).

O tecido adiposo foi classicamente dividido em dois tipos, com origens em células precursoras diferentes, o tecido adiposo branco (TAB) e o tecido adiposo marrom (TAM). O TAB possui papel essencial de armazenamento de energia sob a forma de triglicerídeos (TG) e, em situações de déficit de energia, controla o fornecimento desta para os tecidos pela liberação de ácidos graxos na corrente sanguínea (9). O TAM, em contrapartida, é especializado em dissipar a energia química sob forma de calor, por meio da termogênese adaptativa (10). O marcador da termogênese nos adipócitos é a proteína desacopladora 1 (UCP1), proteína 
mitocondrial responsável por dissipar o gradiente eletroquímico de prótons gerado pela cadeia respiratória na forma de calor (11).

Um terceiro tipo de adipócito, descrito em roedores como tipo celular indutível em depósitos de TAB mediante estímulos termogênicos como exposição crônica ao frio ou sinalização $\beta$-adrenérgica (12), apresenta características morfológicas semelhantes às do adipócito marrom e expressa marcadores de termogênese, como a UCP1, mas apresenta origem e assinatura de transcrição específicas (12). Estes adipócitos são denominados adipócitos bege ou marrom indutíveis.

Adipócitos bege exibem capacidade termogênica $e$, devido à possibilidade de recrutamento destas células com capacidade termogênica no TAB, representam importante foco de pesquisa contra a obesidade (1). Neste contexto, o receptor nuclear ativado por proliferadores peroxissomais gama (PPAR $\gamma$ ), regulador chave da diferenciação de adipócitos branco e marrom (13), tem sido alvo crescente de estudos.

PPAR $\gamma$ apresenta papel essencial na modulação da expressão de genes envolvidos nas vias adipogênicas e lipogênicas e está envolvido também no amarronzamento do $T A B$, ou recrutamento do adipócito bege (14). Ativação de PPAR $\gamma$ por agonistas sintéticos totais conduz ao amarronzamento do TAB por estabilização da ligação da proteína contendo o domínio PR 16 (PRDM16) no complexo do PPARy (15). PRDM16 é um fator de transcrição essencial para o desenvolvimento tanto do TAM clássico a partir dos seus precursores (16) quanto para a expressão do programa genético termogênico em células bege e sua capacidade de realizar respiração desacoplada (17).

Agonistas totais do PPAR $\gamma$, como as tiazolidinadionas (TZD), representadas pela rosiglitazona e pioglitazona, apresentam papel essencial na regulação do metabolismo da glicose e sensibilidade à insulina (18), sendo utilizados na prática clínica como fármacos antidiabéticos. O uso das TZD, no entanto, está associado a efeitos adversos comuns da classe, que incluem ganho de peso, retenção hídrica e edema, fraturas ósseas e risco cardiovascular $(8,19)$. Há ainda efeitos adversos que parecem ser composto-específicos, como risco aumentado de infarto do miocárdio observado com o uso da TZD rosiglitazona (20) e responsável por sua retirada do mercado europeu em 2010 (21). 
A modulação da atividade do PPAR $\gamma$ representa possível estratégia de tratamento do DM2 e resistência à insulina (8). Novos compostos, agonistas parciais ou moduladores seletivos de PPAR $\gamma$, são considerados estratégias mais seguras e efetivas de regular a atividade do PPAR $\gamma$ com finalidade terapêutica por apresentarem o efeito sensibilizador insulínico característico dos agonistas totais do PPAR $\gamma$, mas com ausência dos efeitos indesejáveis (19). O aumento da sensibilidade à insulina observado com agonistas totais (22), agonistas parciais (23) ou mesmo ligantes não-agonistas de PPAR $\gamma$ (24) se relaciona com a inibição da fosforilação do PPAR na Ser ${ }^{273}$ mediada por cinase dependente de ciclina 5 (Cdk5) (21), desvinculando o efeito benéfico do efeito adipogênico característico da ativação total de PPAR $\gamma(19)$.

Apesar de ter sido descrito o amarronzamento do TAB com o agonismo completo de PPAR $\gamma$ pelas TZD (15), agonistas parciais (MRL24) ou moduladores seletivos do PPAR $\gamma$ (SR1664, SR1824) apresentam pouco ou nenhum efeito sobre a expressão de genes relacionado à termogênese (1). O desenvolvimento de ligantes com atividade agonista parcial/moduladora seletiva, capazes de induzir o amarronzamento do TAB sem os efeitos adversos dos agonistas totais do PPAR $\gamma$, poderiam representar estratégia efetiva para o tratamento simultâneo da obesidade e da resistência insulínica. Neste contexto, destaca-se um composto derivado de TZD, GQ-02 (25), que apresentou potente efeito antidiabético in vivo, na ausência de ganho de peso característico das TZD (26), em camundongos com obesidade e diabetes induzidos por dieta hiperlipídica. Além disso, o efeito sobre o peso não foi acompanhado de redução da ingestão de energia, sugerindo a possibilidade de efeito deste composto sobre outros mecanismos que regulam o ganho de peso em resposta à dieta, não representados por redução do aporte energético. $O$ objetivo deste estudo foi, assim, investigar se o efeito do GQ-02 sobre o ganho de peso em resposta à dieta hiperlipídica apresenta contribuição da indução de propriedades termogênicas em depósitos de TAB. 


\section{REVISÃO BIBLIOGRÁFICA}

\subsection{OBESIDADE}

\subsubsection{Definição}

Obesidade e sobrepeso são definidos como acúmulo anormal ou excessivo de gordura no tecido adiposo representando risco à saúde (4). A classificação graduada de excesso de peso em indivíduos adultos utilizada frequentemente em estudos epidemiológicos é baseada no valor do índice de massa corporal (IMC). $\mathrm{O}$ IMC pode ser calculado para indivíduos adultos de todas as idades e a interpretação de seu valor é a mesma para ambos os sexos. É definido como o peso, em quilogramas, dividido pelo quadrado da altura, em metros $\left(\mathrm{kg} / \mathrm{m}^{2}\right)(4)$, e utiliza-se do pressuposto de que a maior variação de peso para as pessoas da mesma altura será devida à massa adiposa (5).

A classificação do estado nutricional segundo o IMC permite comparações da condição de peso dentro e entre populações e a identificação de indivíduos ou grupos em risco de comorbidades (Quadro 1). Permite também identificação de prioridades para intervenções nas perspectivas individual ou comunitária e a avaliação da efetividade de tais intervenções (4).

Quadro 1 - Classificação de indivíduos adultos segundo o IMC.

\begin{tabular}{|c|c|c|}
\hline Classificação & $\mathrm{IMC}\left(\mathrm{kg} / \mathrm{m}^{2}\right)$ & Risco de comorbidades \\
\hline Baixo peso & $<18,5$ & Baixo \\
\hline Peso normal & $18,5-24,9$ & Médio \\
\hline Sobrepeso & $\geq 25,0$ & - \\
\hline Pré-obeso & $25-29,9$ & Aumentado \\
\hline Obeso classe I & $30-34,9$ & Moderado \\
\hline Obeso classe II & $35-39,9$ & Grave \\
\hline Obeso classe III & $\geq 40$ & Muito grave \\
\hline
\end{tabular}




\subsubsection{Epidemiologia}

Estimativas da Organização Mundial de Saúde (OMS) indicam que a obesidade está em crescimento em todo o mundo e que, desde 1980, a prevalência da obesidade mundial mais do que duplicou (2). Estimativas projetavam para o ano de 2030 um número absoluto de indivíduos com sobrepeso de aproximadamente 2 bilhões $(6,27)$, porém foi demonstrado que, em 2014, mais de 1,9 bilhão de indivíduos com idade igual ou superior a 18 anos já estavam acima do peso e, dentre estes, mais de 600 milhões eram obesos (2). No Brasil, a frequência de excesso de peso foi de 52,5\%, sendo maior entre homens do que entre mulheres, e a frequência de adultos obesos foi de 17,9\%, sem diferença entre os sexos (3).

Alterações da prevalência da obesidade na população adulta reflete em impressionante aumento do peso de crianças e adolescentes, tanto em países industrializados quanto em países em desenvolvimento (5). Entre as crianças com idade inferior a cinco anos, 42 milhões apresentavam sobrepeso ou obesidade em $2013(2)$.

Contrariamente a outros principais riscos globais que estão em declínio, tais como tabaco e desnutrição infantil, obesidade e sobrepeso estão em ascensão, particularmente em ambientes urbanos e em países em desenvolvimento (28). A obesidade e o sobrepeso apresentam maior taxa de mortalidade do que o baixo peso (2), representando grande desafio para a saúde pública e a mortalidade em muitos países (28).

De grande interesse são os aumentos simultâneos e paralelos da prevalência de condições patológicas associadas à obesidade (29). Estima-se que 44\% do risco de ocorrência de DM2 seja atribuível às epidemias globais de sobrepeso e obesidade (30).

A maioria das mortes atribuíveis ao excesso de peso é por condições cardiovasculares (28) e indivíduos obesos estão em risco para uma série de doenças associadas, ou não, a maior risco cardiovascular. Além do DM2, destacamse condições como resistência à insulina, intolerância à glicose, dislipidemia, doença cardíaca coronariana, hipertensão arterial, trombose, asma, osteoartrites, doença renal crônica, doença hepática gordurosa não alcoólica, doença de Alzheimer e algumas formas de câncer $(6,29,31)$. 


\subsubsection{Fisiopatologia da obesidade e correlação com o diabetes mellitus tipo 2}

A obesidade ocorre devido ao estado de desequilíbrio entre a ingestão e o gasto de energia, em que há excesso de acúmulo lipídico afetando negativamente a saúde metabólica $(4,30,32)$. Nas últimas décadas, a obesidade tem sido considerada consequência de modificações no estilo de vida, que incluem acesso facilitado a alimentos altamente calóricos, com consequente aumento de seu consumo, juntamente com sedentarismo (6). Embora este conceito básico seja válido, é cada vez mais evidente que a obesidade não pode ser explicada simplesmente como resultado de ingestão excessiva de alimentos ricos em energia em conjunto com falta de atividade física (6).

A obesidade é um distúrbio crônico e complexo que apresenta etiologia multifatorial. $O$ aumento da prevalência de obesidade nos últimos anos sugere que sua ocorrência e complicações estão associadas a outros fatores, tais como genéticos, epigenéticos, sociais, culturais, comportamentais, fisiológicos, metabólicos e ambientais $(6,28,33)$. Estes fatores, por sua vez, influenciam de maneiras variadas a homeostase energética, em especial a fisiologia do tecido adiposo.

Até 1990, os adipócitos eram considerados apenas depósitos de armazenamento para a reserva metabólica em excesso resultante do desequilíbrio energético entre a ingestão e o gasto de energia $(4,6)$. Com a descoberta de um hormônio derivado dos adipócitos, a leptina, que sinaliza sobre a reserva energética para outros órgãos, incluindo o sistema nervoso central (SNC) (34), foram atribuídas ações endócrinas aos adipócitos (35). Posteriormente, foram identificados outros fatores secretados pelo tecido adiposo, denominados adipocinas, que possuem sinalização em outros órgãos, e incluem a resistina, fator de necrose tumoral $\alpha$ (TNF- $\alpha$ ), entre outros (36).

A obesidade também está ligada à expansão patológica do tecido adiposo que gera um estado de inflamação crônica de baixa intensidade e contribui para o desenvolvimento de doenças associadas à obesidade (37) (Figura1).

A expansão patológica do tecido adiposo está relacionada com o aumento do número dos adipócitos (hiperplasia) bem como aumento do volume dos adipócitos (hipertrofia) (38). Nos estágios iniciais da expansão ocorre diminuição do fluxo 
sanguíneo para este tecido em razão da hipertrofia dos adipócitos resultando em áreas de microhipóxia localizada que, por sua vez, desencadeiam mudanças da composição celular dos depósitos de gordura e fibrose $(37,38)$. A redução do fluxo sanguíneo também limita o fornecimento de nutrientes ao tecido e resulta em necrose adipocitária (37).

A necrose dos adipócitos é um eminente estímulo fagocitário que regula a infiltração de macrófagos e células imunitárias no tecido adiposo (37). Diferentes subconjuntos de macrófagos estão envolvidos na inflamação do tecido adiposo induzida pela obesidade. Os macrófagos que se acumulam no tecido adiposo obeso são macrófagos M1, ou classicamente ativados, responsáveis por produzir citocinas pró-inflamatórias como TNF- $\alpha$ e interleucina-6 (IL-6), além de espécies reativas de oxigênio $(39,40)$. Os macrófagos $M 2$, ou alternativamente ativados, estão presentes no tecido adiposo de animais magros e regulam positivamente a produção de citocinas anti-inflamatórias e negativamente a de citocinas pró-inflamatórias (40). Estes dados sugerem que recrutamento e acúmulo dos macrófagos M1 estejam envolvidos em promover a resistência à insulina, enquanto macrófagos M2 protegem contra a resistência à insulina induzida por obesidade (41).

Os macrófagos infiltrados agregam-se ao redor dos adipócitos necróticos e formam estruturas semelhantes a coroas ("crown-like") (42) Estes macrófagos se fundem no processo de fagocitose da gotícula de lipídeo formando amplos sincícios multinucleados carregados de lipídeos, indícios morfológicos do processo de inflamação crônica $(42,43)$.

O resultado do processo de obesidade é um estado de disfunção metabólica em que ocorre recrutamento e acúmulo de células imunitárias ao redor do adipócito necrótico e o aumento da liberação das citocinas pró-inflamatórias, como leptina e resistina, no tecido adiposo. O estado inflamatório do tecido adiposo obeso contribui para a resistência à insulina (37), demonstrado na figura 1. 


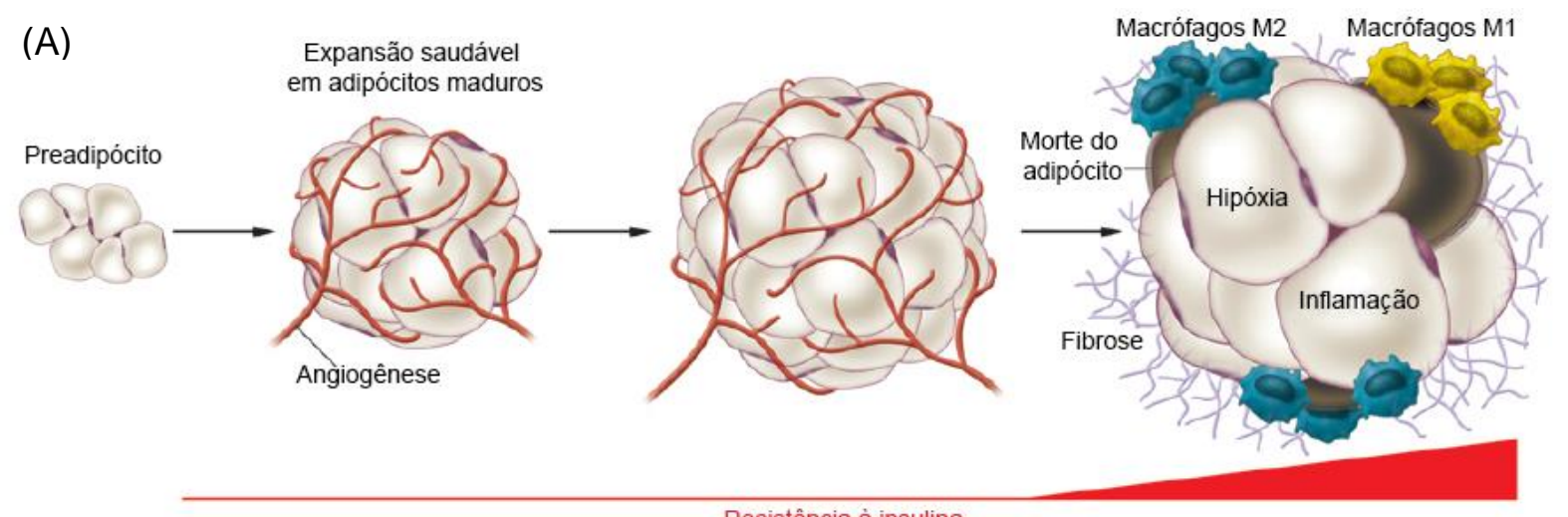

Resistência à insulina

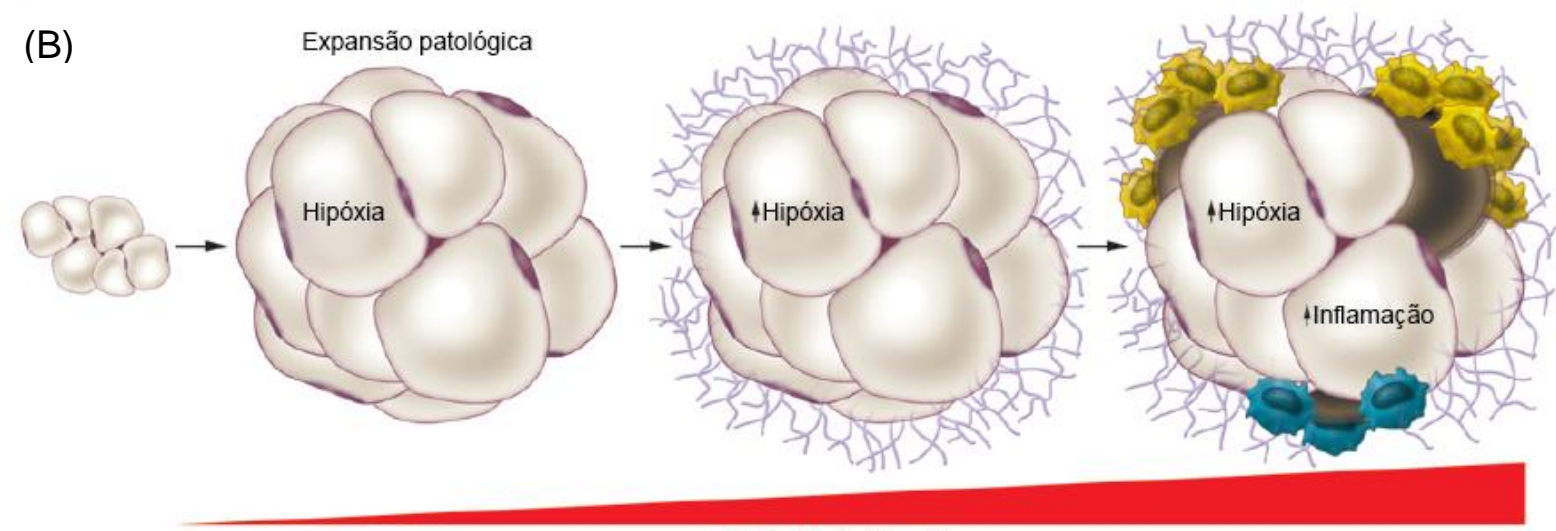

Resistência à insulina

Figura 1 Expansão saudável e patológica do tecido adiposo. O contínuo e excessivo armazenamento de TG pelo adipócito resulta em hipertrofia do tecido adiposo e, muitas vezes, na deposição ectópica de gordura. (A) Expansão saudável ocorre com aumento no recrutamento de células precursoras de adipócitos, que serão diferenciadas em adipócitos, juntamente com recrutamento de outros tipos celulares, vascularização, mínima indução de matriz extracelular e mínima inflamação. (B) Expansão patológica descrita como hipertrofia de células adiposas existentes, elevada infiltração de macrófagos e células imunitárias, limitada angiogênese e fibrose, associada com inflamação crônica que resulta em resistência à insulina. Adaptado de (38).

\subsection{TECIDO ADIPOSO}

O tecido adiposo de mamíferos pode ser dividido em dois tipos principais (44), tecido adiposo branco (TAB) e tecido adiposo marrom (TAM), que apresentam funções diametralmente opostas no metabolismo energético (11).

O TAB é o tecido especializado no armazenamento do excesso de energia na forma de triglicerídeos que, em situações de jejum, são liberados como ácidos graxos para a circulação (45) e que sofre a expansão patológica durante a obesidade, estando diretamente implicado no contexto pró-inflamatório desta condição $(46,47,48)$. 
O TAM, em contraste, é especializado na termogênese adaptativa, ou seja, na produção de calor em resposta a determinados estímulos $(11,47)$. O calor produzido pelo TAM é essencial para a sobrevivência de pequenos mamíferos sob exposição ao frio como também em animais hibernantes (31). O TAM age como defesa contra a hipotermia na maioria, se não todos, os mamíferos e, mais recentemente, foi identificado seu papel protetor contra obesidade e diabetes $(12,48)$.

\subsubsection{Morfologia}

Os adipócitos brancos e marrons apresentam amplas diferenças morfológicas, que correspondem às suas diferenças funcionais, principalmente em termos de estrutura das gotículas lipídicas e quantidade de mitocôndrias (Figura 2). O adipócito branco, responsável pelo armazenamento de energia, apresenta única gotícula de lipídeo rodeado por fina camada de citoplasma, sendo caracterizado como adipócito unilocular. Diferentemente, o adipócito marrom, responsável pela termogênese ou produção de calor, caracteriza-se pelo aspecto multilocular, ou seja, por possuir múltiplas pequenas gotículas de lipídeo em seu citoplasma (44, 49). Quanto ao conteúdo mitocondrial, o TAB possui poucas mitocôndrias e os adipócitos marrons possuem numerosas e grandes mitocôndrias que contém a proteína especializada denominada proteína desacopladora 1 (UCP1) (49).

A UCP1 é um transportador mitocondrial específico do tecido adiposo termogênico responsável por dissipar a energia química resultante do potencial de membrana mitocondrial na forma de calor $(48,50)$. Para tanto, esta proteína, presente na membrana mitocondrial interna, desacopla o gradiente de prótons, gerado na mitocôndria, da síntese de ATP (46). Este gradiente eletroquímico de prótons é gerado durante a passagem de elétrons ao longo da cadeia respiratória e é dissipado pela UCP1 a partir do espaço intermembranoso para a matriz mitocondrial. Esta dissipação, por sua vez, resulta na transformação da energia química em geração de calor (46). Em consistência com seu papel essencial à termogênese, camundongos com deleção homozigota do gene que codifica a UCP1 de fato não são capazes de manter a temperatura corporal quando expostos ao frio (12). 
(A)

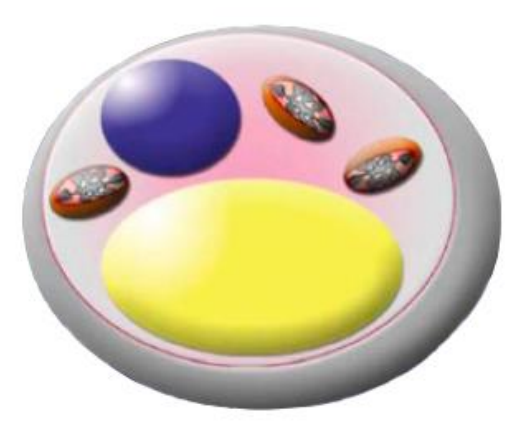

(B)

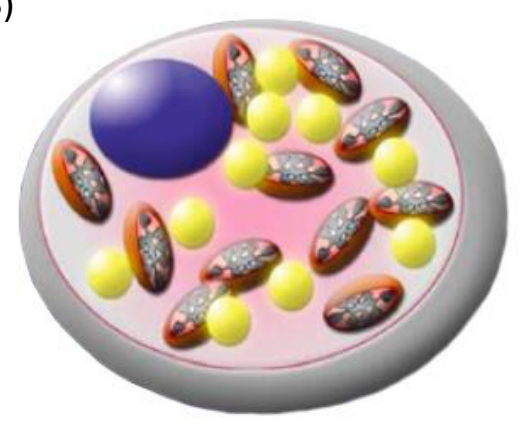

Figura 2 Características morfológicas do adipócito branco e marrom. (A) Adipócito branco apresentando gotícula lipídica unilocular e reduzido conteúdo mitocondrial. (B) Adipócito marrom com múltiplas gotículas lipídicas e amplo número de mitocôndrias com presença de UCP1. Adaptado de (48).

\subsubsection{Adipócito bege e termogênese adaptativa}

O SNC é capaz de detectar mudanças da temperatura corporal e, em situações de exposição crônica ao frio, ativa o tecido adiposo termogênico via catecolaminas secretadas por nervos simpáticos que inervam diretamente no TAM $(51,52)$. A sinalização adrenérgica para o TAM, por sua vez, induz a expressão e atividade da UCP1 e, assim, a termogênese. Em consistência com o papel central da sinalização adrenérgica na termogênese neste depósito adiposo, a ativação do TAM também é observada em resposta à administração de agonistas betaadrenérgico e no contexto de tumores secretores de catecolaminas.

Além de seus efeitos sobre o TAM, a exposição crônica ao frio e ativação $\beta$ adrenérgica são também estímulos para a expressão da UCP1 e da capacidade termogênica de aglomerados de células adiposas localizadas no TAB (31). Estes adipócitos, embora localizados em depósitos de TAB, apresentam gotículas lipídicas multiloculares, alto teor de mitocôndrias e expressam conjunto de genes relacionados à termogênese, característicos do adipócito marrom, como o que codifica a UCP1 (31). Estas células foram inicialmente denominadas adipócitos marrons indutíveis (recrutáveis), ou adipócitos bege, por apresentarem muitas das características morfológicas e moleculares dos adipócitos marrons clássicos (49).

Apesar da semelhante capacidade termogênica, adipócitos bege e marrom clássicos expressam assinaturas genéticas diferentes e características moleculares 
distintas $(12,53)$, devendo ser considerados como dois tipos diferentes de células termogênicas (31). Diferença evidente entre os dois tipos de células é que os adipócitos marrons clássicos expressam altos níveis de UCP1 e demais genes termogênicos sob condições basais, enquanto que os adipócitos bege expressam genes termogênicos apenas quando estimulados, como em resposta a agonistas do receptor $\beta$-adrenérgico $(14,54)$. Outra distinção entre os adipócitos marrom e bege são suas diferentes origens no desenvolvimento. O TAM surge a partir de células precursoras que expressam o fator miogênico $5\left(\mathrm{Myf}^{+}\right)$, e de que derivam também as células musculares (16), enquanto os adipócitos bege não derivam destes precursores $(15,31)$.

A confirmação de que o desenvolvimento do TAM clássico e do tecido muscular esquelético se dá a partir do mesmo precursor foi a identificação de um cofator transcricional que age como regulador dominante para a expressão de genes de adipócitos marrons, a proteína contendo o domínio PR 16 (PRDM16) (16). A ablação de PRDM16 em culturas primárias de adipócitos marrons resultou no desenvolvimento de células musculares esqueléticas, ao passo que a expressão de PRDM16 em mioblastos desviou a diferenciação destas células para adipócitos marrons (16). Assim, os adipócitos marrons clássicos, localizados principalmente na região interescapular de camundongos, se desenvolvem a partir de precursores mioblásticos $\mathrm{Myf5}^{+}$que se diferenciam em adipócitos marrons por ação de reguladores transcricionais (15).

Os adipócitos marrons clássicos e os adipócitos brancos também possuem diferentes origens no desenvolvimento (55), visto que os precursores de adipócitos brancos não expressam os genes miogênicos observados nos precursores de adipócitos marrons (56). Assim, adipócitos bege e brancos derivam de precursores celulares Myf5. A origem e sequência de desenvolvimento dos adipócitos bege não está completamente esclarecida (31) e hipóteses são desenvolvidas a fim de entender se os adipócitos bege se diferenciam a partir da transdiferenciação das células brancas ou a partir da maturação de precursores bege localizados no TAB (31).

Foi demonstrado recentemente que a maioria, se não todos, os adipócitos bege presentes no TAB subcutâneo originam-se a partir de população precursora bege, e não de adipócitos maduros pré-existentes (57). Além disso, a identificação de marcadores de superfície celular específicos de precursores de adipócitos bege, 
como o CD137 e a proteína de transmembrana 26 (Tmem26), isolados a partir da fração vascular estromal, sugeriram não haver a transformação direta de adipócitos brancos maduros em bege, pelo menos em condições fisiológicas (12).

Além da caracterização molecular dos adipócitos termogênicos, marrons e bege, outro foco de pesquisas é a identificação de reguladores transcricionais envolvidos na diferenciação destes tipos de adipócito a partir de seus precursores. Alguns reguladores transcricionais dominantes no desenvolvimento e função dos adipócitos marrons foram identificados e, além da PRDM16, que também está envolvida no desenvolvimento das células bege a partir de seus precursores e em sua atividade $(15,47)$, incluem o coativador $1 \alpha$ do receptor ativado por proliferadores peroxissomais gama (PGC1 $\alpha$ ) (Figuras 3 e 4). A PRDM16 é altamente expressa em depósitos de TAB propensos ao recrutamento de adipócitos bege ou ao "amarronzamento", em camundongos, como o TAB subcutâneo inguinal (47).

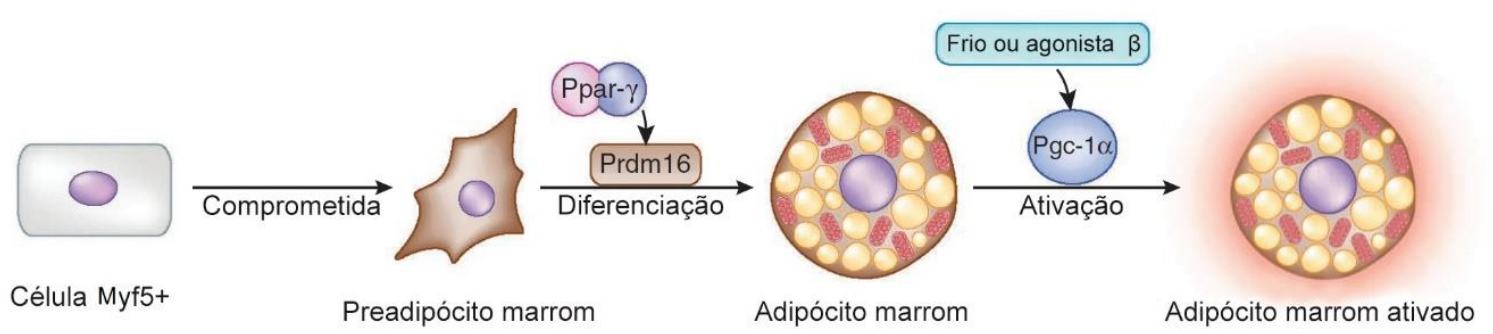

Figura 3 Regulação transcricional do desenvolvimento de adipócitos marrom. Adipócitos marrom são derivados a partir de linhagem progenitora expressando Myf5. PRDM16 conduz à diferenciação do préadipócito marrom em adipócito marrom. Termogênese em adipócitos marrom é ativada por estímulo ao frio ou agonista $\beta 3$, aumentando a expressão e atividade de PGC-1 $\alpha$, coactivador de transcrição que coordena a programação do gene em resposta à ativação. PRDM16, proteína contendo o domínio 16; PPAR $\gamma$, receptor gama ativado por proliferador peroxissomal; PGC-1a, coativador $1 \alpha$ do receptor ativado por proliferadores peroxissomais gama. Adaptado de (31).

O coativador PGC1a é conhecido como regulador principal da biogênese mitocondrial e metabolismo oxidativo em vários tipos celulares, sendo expresso em músculo esquelético, coração, rim, cérebro e tecido adiposo (58). Em adipócitos, o PGC1a induz a transcrição de genes relacionados à termogênese, como o que codifica a UCP1 (31). A expressão e atividade de PGC1 $\alpha$ são reguladas diretamente pela via de sinalização $\beta$-adrenérgica (59), representando a ligação entre o ativador fisiológico da termogênese e a maquinaria transcricional. O PGC1a, ao ser 
fosforilado e ativado em resposta à estimulação simpática $(59,60)$, regula a expressão gênica por interações com receptores nucleares, como o receptor nuclear ativado por proliferadores peroxissomais gama (PPAR $\gamma)(31)$.

Assim, o PGC1a é um fator transcricional central para a ativação da termogênese induzida por frio ou agonistas adrenérgicos em adipócitos marrons clássicos $(61,62)$ e para a expressão dos genes termogênicos em TAB (63). Consistentemente, sua ablação reduz a expressão de muitos genes termogênicos, embora não influencie a expressão de alguns genes seletivos de adipócitos marrons clássicos (55).
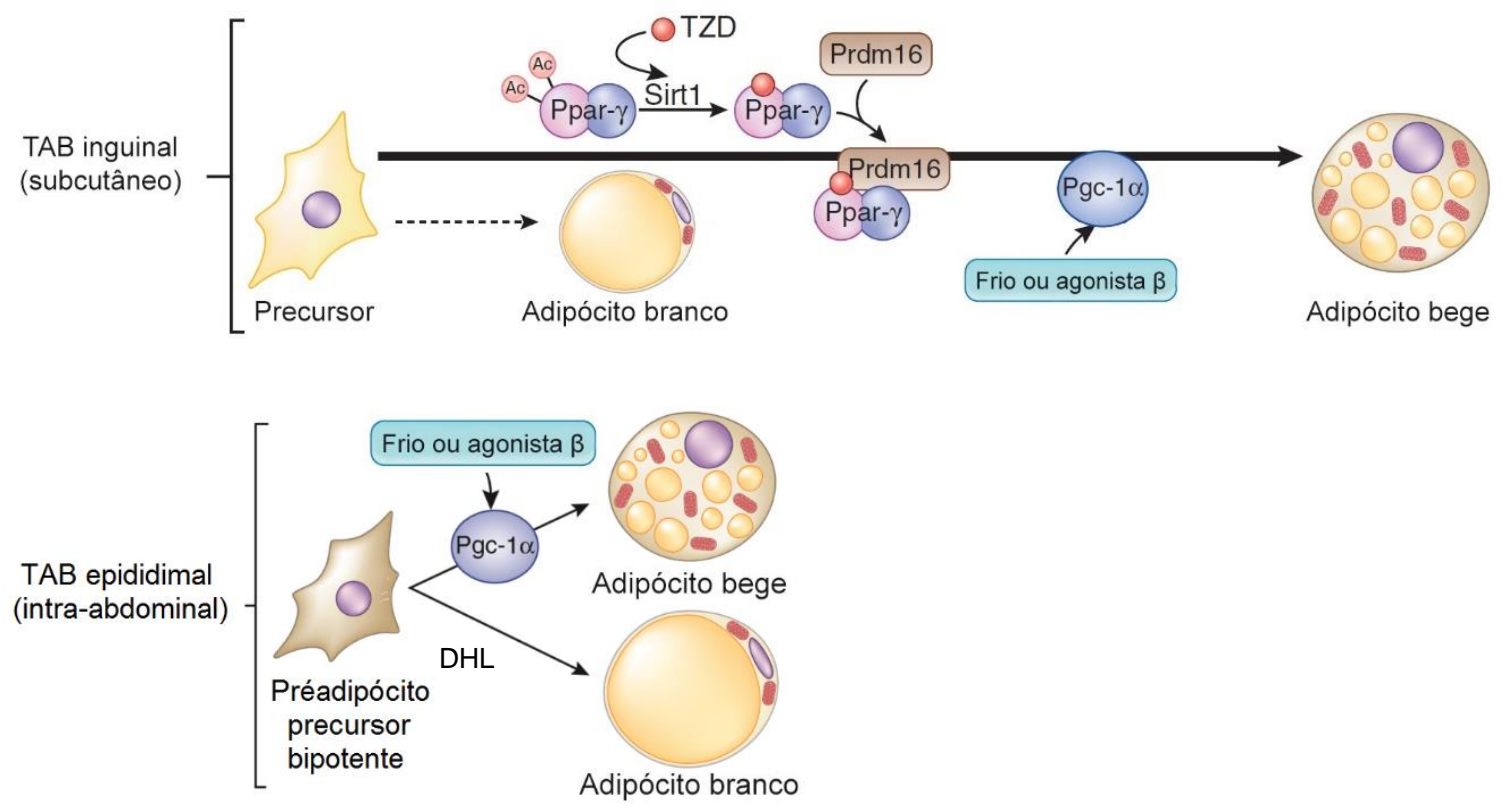

Figura 4 Regulação transcricional do desenvolvimento de adipócitos bege. No TAB inguinal, a estimulação $\beta$-adrenérgica desencadeia predominantemente diferenciação de células precursoras em adipócitos bege, conduzindo à expressão e atividade de PGC-1 $\alpha$ em adipócitos bege. Agonistas de PPAR $\gamma$, TZD promovem o amarronzamento tanto por aumentar a estabilidade de PRDM16 quanto através de desacetilação de PPAR $\gamma$ dependente de SIRT1 (mecanismo que será detalhado posteriormente), que recruta PRDM16 aos genes alvo de PPAR- $\gamma$. No TAB epididimal, o excesso de calorias promove a diferenciação de células progenitoras em adipócitos brancos enquanto que a ativação $\beta$-adrenérgica estimula o desenvolvimento de adipócitos bege. PRDM16, proteína contendo o domínio 16; PPAR $\gamma$, receptor gama ativado por proliferador peroxissomal; PGC-1a, coativador $1 \alpha$ do receptor ativado por proliferadores peroxissomais gama; Ac, acetilação; SIRT1, desacetilase dependente de NAD sirtuína 1. Adaptado de (31). 


\subsubsection{Distribuição do tecido adiposo}

Determinados depósitos de tecido adiposo em humanos não possuem correspondentes precisos em camundongos, e vice-versa. Grande proporção da gordura visceral nos humanos está contida no omento, tecido que é escasso em roedores. Por outro lado, grandes depósitos de gordura epididimal de camundongos machos, amostradas frequentemente como representantes da gordura visceral, não possuem correspondentes bem definidos nos humanos (55). Os depósitos subcutâneos em camundongos são supridos por vasos e nervos específicos, principalmente noradrenérgicos, que também são característicos no TAM (49), sendo que esta semelhança parece estar envolvida na indução de propriedades termogênicas em adipócitos subcutâneos em resposta ao frio, estimulação betaadrenérgica ou outros hormônios (17).

\subsubsection{Tecido adiposo branco}

Determinantes das condições associadas à obesidade são influenciadas não apenas pela magnitude do excesso de gordura corporal como também pela distribuição regional da gordura $(4,5,64)$. Diferentes tipos de depósitos de tecido adiposo existem com relação à sua localização anatômica, sendo que diferem, também, com relação à sua função endócrina, atividade lipolítica, resposta à insulina e a outros hormônios (64).

Duas grandes categorias de obesidade são reconhecidas, a obesidade visceral, caracterizada por aumento dos depósitos de gordura localizados em torno dos órgãos, e a obesidade subcutânea, caracterizada por aumento dos depósitos sob a pele (50). Existem, ainda, distinções entre depósitos de gordura visceral de acordo com a sua localização, como perigonadal, mesentérica, retroperitoneal, entre outros (55).

As diferenças das condições associadas à expansão dos dois tipos principais de TAB, visceral e subcutâneo, estão fortemente relacionadas ao processo inflamatório, intenso no primeiro. De fato, os macrófagos são mais abundantes no 
tecido adiposo visceral do que no subcutâneo, e este maior recrutamento para o tecido adiposo visceral está relacionado à inflamação crônica e desenvolvimento da resistência insulínica (37).

A deposição visceral intra-abdominal do tecido adiposo, caracterizando a obesidade superior, é mais frequentemente associada ao desenvolvimento de hipertensão arterial, hiperinsulinemia, resistência à insulina, DM2 e hiperlipidemia (5). A adiposidade visceral está fortemente associada com aumento da mortalidade, mesmo em indivíduos com IMC normal (65), enquanto que a adiposidade subcutânea parece ser relativamente benigna (66).

\subsubsection{Tecido adiposo marrom}

O TAM, tecido termogênico, é uma adaptação dos mamíferos mais evidente em pequenos roedores e crianças (52). A necessidade de maior quantidade de TAM em animais menores ocorre devido à maior área de superfície em relação ao volume se relacionando, assim, com um maior risco de hipotermia (46). Mamíferos maiores, porém, perdem estes depósitos após a infância (67).

Em seres humanos, os depósitos de TAM foram caracterizados primeiramente em fetos e recém-nascidos, como medida de proteção durante as primeiras horas após o nascimento em ambiente frio, sendo localizados nas regiões perirrenal, periadrenal, axilares e cervical $(52,67)$.

Em humanos adultos, método de imagem funcional de tomografia por emissão de pósitrons utilizando glicose marcada com flúor 18 e combinado com tomografia computadorizada (PET-CT) identificou áreas discretas de tecido adiposo metabolicamente ativo, sugestivas de TAM (68). De fato, a análise imunohistoquímica de amostras deste tecido evidenciou adipócitos marrons UCP1positivos $(68,70)$ que, independentemente da idade ou sexo, foram encontrados em seres humanos adultos nas regiões cervical e toráxica superior. Foi observado, ainda, que estímulos adrenérgicos, como exposição ao frio, ativavam estes depósitos de TAM e promoviam sua expansão, e que sua presença em seres humanos correlaciona-se inversamente tanto com a quantidade de gordura corporal quanto com a idade $(49,71)$. A presença de TAM ativo em humanos adultos e sua 
correlação com indicadores de saúde metabólica sugerem a capacidade de alterar a quantidade e atividade destes depósitos como estratégia terapêutica para a obesidade e distúrbios a ela relacionados, como o DM2 (46).

Os adipócitos dos depósitos de tecido adiposo termogênico visualizados em humanos adultos e considerados de TAM compartilham mais propriedades moleculares com os adipócitos bege, identificados inicialmente em roedores, do que especificamente com o TAM clássico $(12,53,72)$ (Figura 5). Em neonatos humanos, no entanto, na região interescapular, os adipócitos apresentam características de TAM clássico e, com o crescimento até a vida adulta, a quantidade destas células diminui e passa a ser observado predomínio de adipócitos bege $(72,73,74)$.

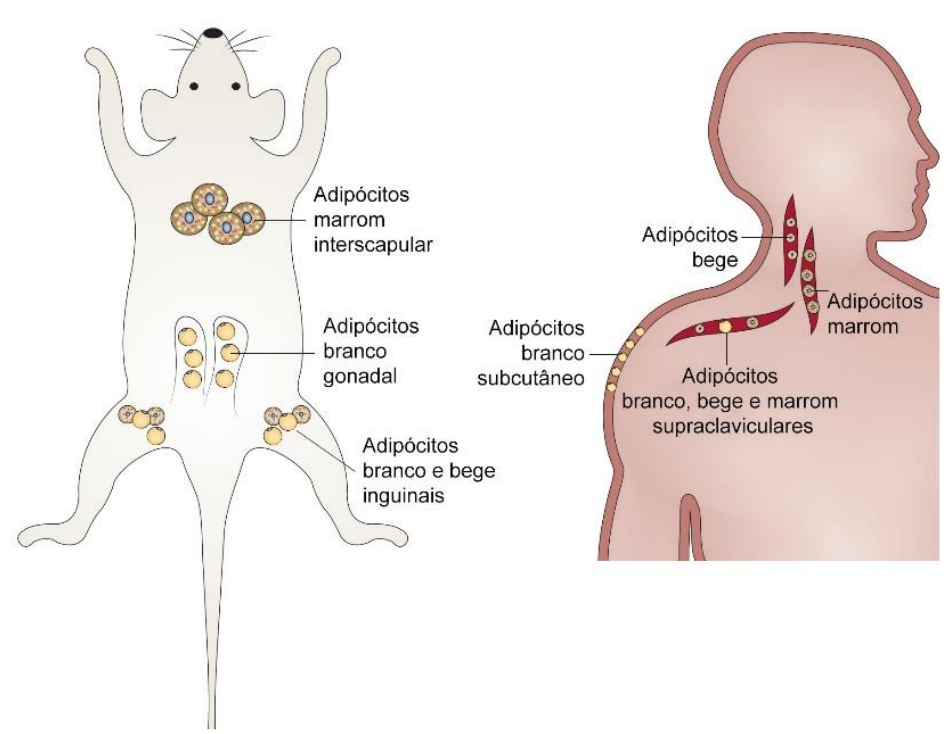

Figura 5 Localização anatômica predominante dos adipócitos marrom, branco e bege em camundongos e humanos adultos. Adaptado de (71).

\subsection{RECEPTORES NUCLEARES}

Receptores nucleares (RN) constituem uma superfamília de fatores de transcrição que apresentam domínios estruturais altamente conservados e são ativados por pequenos compostos lipofílicos (75). Estes receptores regulam a expressão de genes envolvidos em ampla variedade de processos fisiológicos e do desenvolvimento (75). 
Os genes que codificam estes receptores parecem ter surgido na cena evolutiva há aproximadamente 635 milhões de anos e estão expressos em alguns dos organismos mais simples. Evolutivamente, os RN estão associados à explosão Cambriana, diversificação maciça a partir de organismos relativamente simples, principalmente unicelulares, para organismos multicelulares e morfologicamente mais complexos, organizados em tecidos e órgãos (75). Estão ausentes, porém, em fungos, plantas e ciano flagelados (76). Os mamíferos, incluindo camundongos e seres humanos, possuem aproximadamente 48 genes que codificam RN (75).

Os ligantes de RN incluem hormônios, vitaminas lipofílicas e metabólitos de colesterol $(75,77)$. Os receptores nucleares que possuem ligantes identificados se tornaram alvos bem caracterizados para o desenvolvimento de drogas eficazes para tratamento de inúmeras disfunções, incluindo DM2 e distúrbios endócrinos e reprodutivos (77), visto que os fármacos mais eficazes são normalmente pequenos compostos hidrofóbicos que podem atravessar a membrana plasmática e ativar 0 RN. Há, ainda, os receptores órfãos, que não possuem ligantes conhecidos e correspondem a aproximadamente metade dos RN em mamíferos (77). Em organismos não mamíferos, o número de RN com ligantes identificados é ainda menor (75).

Estruturalmente, os $\mathrm{RN}$ apresentam sequências altamente conservadas e, considerando o seu grau de homologia, foram definidas seis sub-regiões estruturais comuns a estes receptores, denominadas de regiões A a F (77) (Figura 6).

$A$ região amino-terminal ou $A / B$ é a região mais divergente entre os $R N$ e contém um domínio de ativação independente de ligante, denominado função de ativação 1 (AF-1), em muitos receptores. A região $C$ corresponde ao domínio mais conservado e apresenta dois segmentos estruturais conhecidos como "dedos de zinco", que determinam a ligação do RN a regiões específicas de DNA, formando o domínio de ligação ao DNA (DBD). A região $D$ é chamada de dobradiça, localiza-se entre o DBD e o LBD e é uma região relativamente curta e com baixo grau de conservação, que desempenha papel na modulação da ligação dos receptores ao DNA. A região E corresponde ao domínio de ligação ao ligante (LBD) e contém o domínio de ativação dependente de ligante, ou função de ativação 2 (AF-2) (77). 0 domínio $\mathrm{E}$ oferece as principais superfícies para a dimerização do $\mathrm{RN}$, além da interação com cofatores da transcrição (78). O domínio $\mathrm{F}$, adicional em direção à 
região carboxi-terminal do domínio $E$, é observado apenas em alguns receptores e não possui função definida (77).
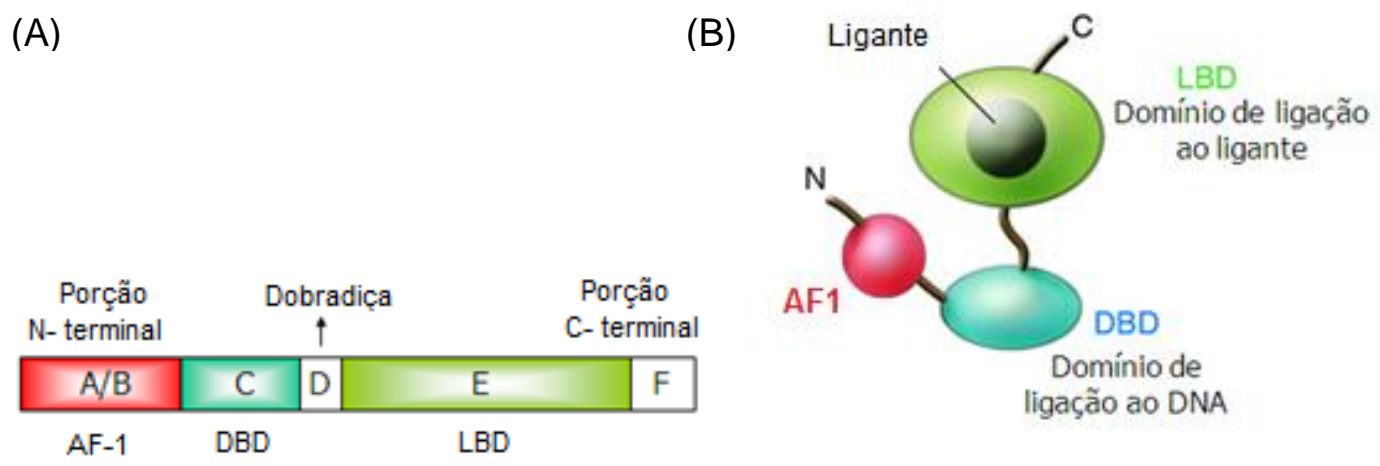

Figura 6 Estrutura geral dos receptores nucleares. (A) Estrutura primária representando a região amino-terminal (domínio $A / B$, em que se encontra o domínio função de ativação 1 ou AF-1), domínio de ligação ao DNA (DBD, domínio $C$ ), região de dobradiça (domínio $D$ ), região carboxi-terminal ou domínio de ligação ao ligante (LBD, domínio $E$ ), e domínio $F$. (B) Estrutura secundária representando as regiões amino $(\mathrm{N})$ e carboxi-terminais (C), AF-1, DBD e LBD. Adaptado de (79).

\subsubsection{Ativação dos receptores nucleares}

Os RN compartilham sequência de aminoácidos altamente conservada nos domínios principais, o DBD e o LBD (75). O LBD corresponde a estrutura terciária formada quase que exclusivamente por $\alpha$-hélices dispostas em camadas (80) e os ligantes de RN se ligam no interior deste domínio por possuírem característica hidrofóbica.

Para regular a transcrição em resposta aos ligantes, os RN reconhecem elementos responsivos nas regiões promotoras específicas de seus genes alvos no DNA e, assim, promovem o recrutamento dos correguladores responsáveis por modificações estruturais da cromatina e alteração da capacidade de recrutamento de fatores transcricionais gerais que alteram a taxa de expressão gênica $(75,77)$.

A a-hélice 12 (H 12) do LBD demonstra ser essencial para a ativação clássica dos RN por estar envolvida em mudanças estruturais conformacionais do RN e sua interação com correguladores (coativadores ou correpressores) da transcrição (77). $\mathrm{Na}$ ausência de ligante, a H 12 apresenta movimentação instável. Com a ativação 
por ligante, a H 12 estabiliza sua posição a fim de manter o contato tanto com o ligante quanto com os correguladores. Além de ligação do ligante, o LBD é necessário para eficiente homo- ou heterodimerização do $\mathrm{RN} e$, com esta conformação, o LBD forma um sulco hidrofóbico em sua superfície que é crucial para o reconhecimento do motivo estrutural $L X X L L$ ( $L=$ leucina e $X=q u a l q u e r$ aminoácido), encontrado na maioria das proteínas coativadoras e permitindo a sua ligação (77).

\subsection{PPAR}

Receptores ativados por proliferadores peroxissomais (PPAR) são fatores de transcrição ativados por ligantes membros da superfamília de RN (78). Em mamíferos existem três isoformas de PPAR, PPARa, $-\beta / \delta$ e $-\gamma$ (81). Cada isoforma de PPAR possui funções in vivo características devido à distinta distribuição tecidual, diferentes respostas a ligantes e também diferenças inerentes às propriedades bioquímicas (81), conduzindo assim à regulação de diferentes conjuntos de genes (82) envolvidos na adipogênese, metabolismo de lipídeos e manutenção da homeostase metabólica $(78,81)$. PPAR também são expresso em macrófagos, apresentando função fundamental na modulação da resposta inflamatória (83).

À semelhança dos diversos membros de receptores nucleares, os PPAR são formados pelos domínios funcionais conservados e se heterodimerizam com os receptores do ácido 9-cis retinóico $(\mathrm{RXR})$ para regular a transcrição de genes alvo (84). PPAR podem ser ativados por ácidos graxos alimentares e seus derivados metabólicos e atuam como sensores lipídicos que, quando ativados, podem redirecionar o metabolismo (81).

\subsubsection{PPAR $\gamma$}

O receptor gama ativado por proliferadores peroxissomais (PPAR $\gamma$ ) é um fator de transcrição ativado por ligantes com papel essencial na ativação da adipogênese 
(85), além de modular o metabolismo lipídico, homeostase da glicose, sensibilidade à insulina e respostas inflamatória e imunitária (8), se apresentando como alvo de tratamento para o DM2.

O processamento alternativo do transcrito do gene do PPAR $\gamma$ resulta, em seres humanos, em três variantes de RNA mensageiros (RNAm) e duas isoformas da proteína $(77,78)$. Os transcritos 1 e 3 codificam para a mesma isoforma de proteína, o PPAR 1 , e o transcrito 2 codifica para o fator de transcrição PPAR $\gamma 2$ (86).

O PPARy2 possui 505 aminoácidos em sua estrutura e é expresso principalmente no tecido adiposo. O PPAR $\gamma 1$ difere do PPAR $\gamma 2$ pela ausência de 28 aminoácidos na extremidade $\mathrm{N}$-terminal e é expresso em grande variedade de tecidos (77). A expressão de PPAR 22 está restrita ao tecido adiposo sob condições fisiológicas, porém pode ser induzida em demais tecidos com uma dieta rica em lipídeos (81).

Ensaios in vivo e em cultura celular revelaram, desde o desenvolvimento de linhagens de pré-adipócitos imortais, na década de 1970 (58), as vias moleculares que controlam o processo de diferenciação dos adipócitos a partir dos pré-adipócitos (46).

Classes de fatores de transcrição foram identificadas por influenciarem diretamente o desenvolvimento das células adiposas incluindo, além do PPAR $\gamma$, membros da família de fatores de transcrição C/EBP (proteínas de ligação ao amplificador CCAAT (citosina/ citosina/ adenosina/ adenosina/ timidina)) (87). Os C/EBP agem como homo- ou heterodímeros e sua distribuição nos tecidos não está limitada apenas ao tecido adiposo (58). Membros da família C/EBP, C/EBPa, - $\beta$ e - $\delta$, participam da ativação e manutenção da expressão de genes induzidos na adipogênese (46) e dados de análises do genoma indicaram que podem, inclusive, modular ou promover diretamente a atividade do PPAR $\gamma$ na maioria de seus sítios de ligação (85).

Assim, a cascata de transcrição que ocorre no processo da adipogênese envolve a ativação sequencial de C/EBP e PPAR $\gamma$. A expressão de C/EBP $\beta$ e $-\delta$ precede a expressão de PPAR $\gamma$, provavelmente por efeito de transcrição direta em sítios de ligação de C/EBP no promotor de PPAR $\gamma$, visto que a expressão ectópica de C/EBPß e -ס conduzem à indução da expressão do RN. O PPAR $\gamma$, em sequência, 
é responsável por induzir a expressão do C/EBPa. Em concordância, foi observado que a expressão ectópica de PPAR $\gamma$ ou ligantes específicos de PPAR $\gamma$ induziram a expressão do RNAm de C/EBPa $(88,89)$. O C/EBPa e o PPAR $\gamma$ mantêm a cascata de transcrição e o adipócito diferenciado por reforçarem mutualmente suas expressões (46). O C/EBPß, além de ser um indutor precoce da expressão de PPAR $\gamma$, pode também cooperar com o PPAR $\gamma$ em adipócitos maduros (85).

PPAR $\gamma$ regula distintos genes alvo em células adiposas brancas e marrons (31), por interferência dos fatores correguladores. O PPAR $\gamma$ é expresso também em níveis relativamente elevados no TAM (58), controlando a expressão de genes característicos de adipócitos marrons, como a UCP1, em resposta a ativadores $\beta$ adrenérgicos $(58,59,90)$.

Nos adipócitos marrons, o corregulador PRDM16 se liga ao C/EBP $\beta$ e recruta proteínas correpressoras que impedem a expressão dos genes associados ao TAB ou desenvolvimento muscular $(91,92)$. Nestas células, ainda, o fator transcricional PGC1 $\alpha$ age por interação direta com o PPAR $\gamma$, que ativa o promotor da UCP1 (58).

Ligantes de PPAR $\gamma$ incluem diversidade surpreendente de moléculas naturais e sintéticas (8). A identidade dos ligantes endógenos que regulam a ação dos $\mathrm{RN}$ in vivo permanece não totalmente elucidada, mas várias moléculas tem sido apontadas como ativadores de PPAR $\gamma$, como ácidos graxos poli-insaturados, prostanoides, ácidos graxos oxidados, ácidos graxos nitrados e ácido lisofosfatídico (93), embora em concentrações muito elevadas e, possivelmente, suprafisiológicas (82).

Dentre os ligantes sintéticos de PPAR $\gamma$, os melhores caracterizados pertencem à classe de fármacos tiazolidinadionas (TZD), potentes sensibilizadores insulínicos.

\subsection{TIAZOLIDINADIONAS}

Pioglitazona e rosiglitazona, representadas na Figura 7, são TZD que agem como potentes agonistas de PPAR $\gamma$ e induzem notável sensibilização à insulina, diminuindo as concentrações séricas de glicose (85). As TZD foram desenvolvidas 
na década de 1990 e foram amplamente utilizadas para o tratamento do DM2, por promoverem significativa melhora do controle glicêmico (8).

(A)

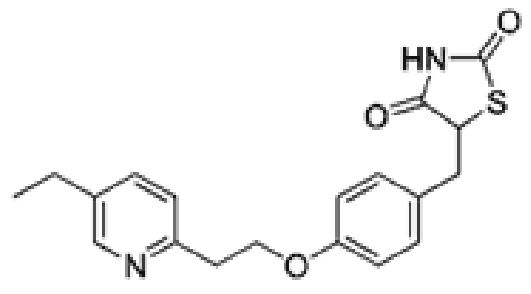

(B)<smiles>CN(CCOc1ccc(CC2SC(=O)NC2=O)cc1)c1ccccn1</smiles>

Figura 7 Estrutura química das TZD clássicas. (A) TZD pioglitazona e (B) rosiglitazona

\subsubsection{Efeitos metabólicos das TZD}

A ativação de PPAR pelas TZD nos adipócitos brancos aumenta a capacidade de expansão desses adipócitos e, consequentemente, o deslocamento do armazenamento intracelular de lipídeos do fígado e músculo, onde seu acúmulo é prejudicial à sinalização da insulina, para o tecido adiposo branco, agindo assim como redutor da lipotoxicidade (18). Esta melhora da resistência à insulina acompanhada de aumento da capacidade adipogênica no TAB é responsável, pelo menos em parte, pelo efeito de ganho de peso associado às TZD (19).

A ativação do PPAR $\gamma$ no tecido adiposo também resulta em regulação positiva dos genes envolvidos na captação da glicose e controla a expressão de fatores secretados pelo adipócito (19), as adipocinas (Figura 8). A adiponectina, cuja expressão apresenta-se aumentada em resposta às TZD (94), desempenha papel central em seus efeitos sensibilizadores insulínicos (82) e, em concordância, camundongos com deficiência de adiponectina não foram responsivos aos efeitos antidiabéticos das TZD (95). 


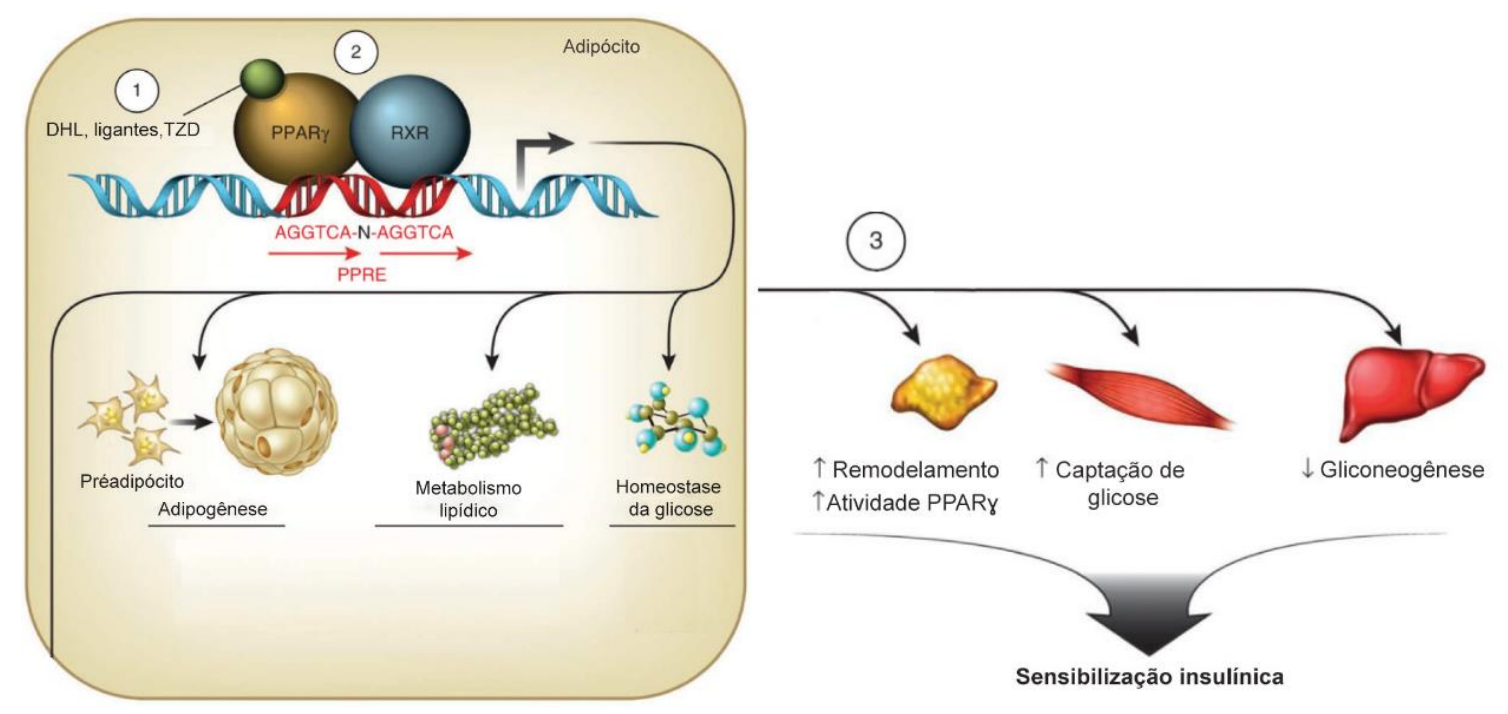

Figura 8 Funções da ativação de PPAR $\gamma$ no tecido adiposo. (1) DHL, ligantes ou TZD ativam PPAR que (2) se heterodimeriza com o receptor RXR. A homeostase metabólica é mantida através de regulação de genes que ancoram o elemento responsivo de PPAR (PPRE), envolvidos na diferenciação de adipócitos, no metabolismo lipídico e na homeostase da glicose. (3) Fatores secretados pelo adipócito atuam em diferentes tecidos alvo promovendo o remodelamento do tecido adiposo, aumento na captação de glicose pelo músculo esquelético e redução da gliconeogênese hepática, resultando em sensibilização insulínica. Adaptado de (19).

O PPAR $\gamma$ é também expresso em níveis reduzidos em uma série de tecidos, que podem ser alvos diretos das TZD e contribuir para seus efeitos sensibilizadores insulínicos, assim como para os efeitos secundários indesejáveis $(96,97)$.

O fígado expressa baixos níveis do PPAR $\gamma$, mas se apresenta como importante sítio de ação das TZD. Os efeitos do agonismo de PPAR $\gamma$ sobre o fígado, no entanto, são divergentes quando se comparam dados de estudos em roedores e humanos. Foi demonstrado que a ativação de PPAR em camundongos promove esteatose hepática por indução da expressão de genes lipogênicos $(98,99)$. Além disso, o nocaute do PPAR $\gamma$ específico no fígado, em camundongos com obesidade induzida por dieta, reduziu a esteatose hepática, embora tenha sido acompanhado de aumento da adiposidade e resistência à insulina (98). A explicação para o aumento da resistência insulínica causado pela ablação específica do PPAR $\gamma$ no fígado é a redução da capacidade do fígado de captar triglicerídeos, o que resulta no armazenamento destes em outros locais como o tecido muscular, que determina 0 aumento da resistência insulínica (98). A ablação do PPAR $\gamma$ no fígado não influenciou, no entanto, o efeito sensibilizador insulínico da rosiglitazona. Foi 
observado também que a ausência de PPAR $\gamma$ no fígado e no músculo não foi essencial para os efeitos benéficos da TZD rosiglitazona em camundongos (98).

Em humanos, porém, o tratamento com TZD apresentou efeito benéfico no tratamento da esteatose hepática $(100,101)$. Isto sugere que, em humanos, o potencial lipogênico das TZD no fígado é compensado pela capacidade em promover o armazenamento dos ácidos graxos no $\operatorname{TAB}(82,102,103)$.

O PPAR $\gamma$ também possui papel importante em células do sistema imunológico, como os macrófagos (19). Foi demonstrado que ativação de PPAR $\gamma$ apresenta efeito antiinflamatório em macrófagos M1 e promove a polarização de monócitos humanos em macrófagos M2, alternativamente ativados (104). Em concordância, o nocaute de PPAR $\gamma$ específico em macrófagos de camundongos promove resistência à insulina e relevante atenuação dos efeitos sensibilizadores insulínicos das TZD $(105,106)$. Tratamento com TZD e ativação do PPAR $\gamma$ contribuem, assim, para a modulação imune e inflamatória dos macrófagos promovendo sua polarização em macrófagos M2 antiinflamatórios no TAB (82).

O PPAR também exerce funções críticas na modulação da inflamação vascular e aterosclerose (82) e o tratamento com TZD reduz a expressão de marcadores inflamatórios, como o TNF- $\alpha$, na parede arterial e o tamanho das lesões ateroscleróticas em modelo de camundongo nocaute para o gene do receptor de LDL (LDLR-/-) (107).

\subsubsection{Efeitos adversos das TZD}

As TZD, além de efeitos benéficos sensibilizadores insulínicos, apresentam também efeitos desfavoráveis resultantes da ativação do PPAR $\gamma$, como ganho de peso, retenção hídrica, perda óssea e problemas cardiovasculares.

O efeito adverso comumente observado de ganho de peso induzido pelo uso das TZD é atribuído à ativação do PPAR $\gamma$ nos adipócitos e indução da adipogênese. Além disso, recentes estudos in vivo e em humanos demonstraram papel da ativação central do PPAR $\gamma$ na homeostase energética (19). A ativação do PPAR $\gamma$ no 
SNC, mais do que a ativação no tecido adiposo, induz o aumento da ingestão alimentar que contribui para o ganho de peso induzido pelas TZD $(108,109)$.

O aumento da adipogênese com tratamento por TZD está associado a redistribuição do tecido adiposo, caracterizado por aumento do tecido adiposo subcutâneo e concomitante diminuição do tecido adiposo visceral $(110,111)$. Apesar de promover aumento global da adiposidade, a redistribuição do tecido adiposo pelas TZD é geralmente considerada benéfica, visto o efeito desfavorável que a obesidade visceral acarreta na sensibilidade à insulina (112).

Ainda como efeito adverso associado ao uso de TZD, é observada redução da massa óssea e maior taxa de fraturas (113), principalmente em mulheres com DM2 (114). As TZD causam perda óssea por suprimir a formação óssea, ou seja, diminuindo a osteoblastogênese, e por promover a reabsorção óssea, ou seja, aumentando a osteoclastogênese $(115,116)$.

Outro efeito adverso característico do uso de TZD é a retenção hídrica com consequente edema, resultantes da ativação do PPAR $\gamma$ no rim (113). Estratégias destinadas a eliminar este aspecto da sinalização do PPAR $\gamma$ seriam extremamente benéficas pois, além do impacto sobre o ganho de peso, a redução da retenção hídrica também poderia reduzir o risco de eventos cardiovasculares, tais como a insuficiência cardíaca congestiva (19).

As TZD contribuem para a retenção hídrica por alterarem a reabsorção de sódio e água nos ductos coletores renais distais $(117,118)$, por mecanismos ainda não completamente elucidados. A expansão do volume plasmático secundária à reabsorção renal de água aumenta a pressão luminal na microvasculatura que, por sua vez, resulta em aumento do gradiente de pressão através da parede dos microvasos conduzindo, portanto, o fluxo de fluido para o compartimento intersticial. Este é considerado o principal mecanismo envolvido no desenvolvimento de edema periférico. A ação direta das TZD nas células endoteliais, mediada pelo PPAR $\gamma$, também tem sido implicada em aumentar a permeabilidade vascular (119).

O aumento do risco de insuficiência cardíaca congestiva associado ao tratamento com TZD tem sido tradicionalmente relacionado com a sua propensão em induzir expansão do volume plasmático e, consequentemente, aumentar a carga cardíaca. No entanto, o papel do PPAR $\gamma$ no coração tem sido controverso (83). A hipertrofia cardíaca observada em resposta ao tratamento com TZD envolve tanto 
vias independentes quanto dependentes do PPAR $\gamma$, visto que camundongos nocautes para PPAR $\gamma$ específico em cardiomiócitos desenvolveram hipertrofia cardíaca e o tratamento de ambos, camundongos selvagens e nocaute, com rosiglitazona também induziu hipertrofia cardíaca (120).

Apesar de alguns estudos demonstrarem ausência de efeitos cardíacos desfavoráveis com o uso de TZD, uma metanálise publicada em 2007 indicou significante aumento do risco de infarto do miocárdio e mortalidade cardiovascular em pacientes tratados com a TZD rosiglitazona (20) e iniciou preocupações sobre a segurança cardiovascular do medicamento (83). Outras meta análises efetuadas posteriormente ou confirmaram os achados iniciais ou foram inconclusivas, mas nenhuma refutou a associação entre rosiglitazona e risco aumentado de infarto do miocárdio (83). Além disso, a metanálise de 2007 foi atualizada em 2010, com uso de análise alternativa e inclusão de ensaios sem eventos cardiovasculares, e ainda assim foram confirmados os dados prévios de que a TZD rosiglitazona estaria associada a aumento no risco de infarto do miocárdio (121). Em 2010, o acesso à TZD rosiglitazona ficou restrito nos Estados Unidos e houve recomendação para sua retirada do mercado na Europa (21).

A pioglitazona não foi associada aos mesmos riscos cardiovasculares da rosiglitazona, visto que ensaio clínico randomizado indicou risco reduzido dos principais eventos cardiovasculares em diabéticos do tipo 2 de alto risco cardiovascular que receberam pioglitazona por período de 3 anos (122). Preocupações sobre a pioglitazona têm sido levantadas em relação à insuficiência cardíaca congestiva (123) e câncer de bexiga $(124,125)$, e este último aspecto motivou e elaboração de avisos de segurança ou mesmo retirada do fármaco em algumas regiões da Europa (19).

\subsubsection{Ativação de PPAR $\gamma$ por TZD e modulação seletiva}

As lacunas na compreensão de como a ativação de PPAR $\gamma$ por pequenas moléculas se correlaciona com o efeito antidiabético ou efeitos adversos tem dificultado o desenvolvimento de tratamentos direcionados ao receptor (85). PPAR $\gamma$ 
interage através de seu LBD com muitas moléculas pequenas estruturalmente diferentes e apesar de vários metabolitos endógenos com baixa afinidade para PPAR $\gamma$ terem sido descritos, ligantes endógenos de alta afinidade são ainda desconhecidos (126).

Ligantes de PPAR $\gamma$ podem induzir espectro de respostas graduadas, incluindo agonismo, completo ou parcial, antagonismo e, ainda, agonismo inverso (85). A região $\mathrm{E}$ do $\operatorname{PPAR} \gamma$ formada pelo $\mathrm{LBD}$, que consiste em 275 resíduos de aminoácidos, e pela região AF-2, consiste de $13 \alpha$-hélices e uma pequena região de 4 folhas $\beta$ (127).

O LBD do PPAR $\gamma$ é grande e acomoda agonistas totais tais como as TZD, que promovem mudança conformacional do PPAR $\gamma$ por estabilização da hélice $\mathrm{H} 12$ em direção às hélices $\mathrm{H} 3$ e H 5 , resultando em uma conformação mais compacta e rígida e na formação de um sulco hidrofóbico (128). Essa alteração conformacional permite o recrutamento de cofatores que são requeridos para a transcrição de genes (128). Em contraste com o agonismo total, os agonistas parciais ou antagonistas de PPAR $\gamma$ tendem a desestabilizar a hélice $H 12$ e estabilizar a hélice $H 3$ e a região de folhas $\beta$ do LBD (128).

Os compostos que tendem a ativar PPAR $\gamma$ de uma maneira, em geral, mais fraca do que as TZD foram denominados agonistas parciais ou moduladores seletivos de PPAR $\gamma$ (129). Dependendo da alteração conformacional do LBD desencadeado por sinalização de moléculas pequenas, proteínas coativadoras distintas, tais como o PGC-1a, ou proteínas correpressoras, tais como o correpressor de receptor nuclear 1 (NCoR1), podem ser recrutadas junto ao PPAR $\gamma$ e modificar a sua atividade (130).

Moduladores seletivos foram desenvolvidos para otimizar as assinaturas de expressão gênica com o objetivo de gerar efeitos metabolicamente benéficos e reduzir os efeitos indesejados, como o composto sintético MRL24 (128), que demonstrou efeito sensibilizador insulínico com reduzido efeito adverso de adipogênese (22).

Assim, o posicionamento distinto de ligantes dentro do LBD do PPAR $\gamma$ tornouse uma abordagem para desenvolver alternativas para modular a atividade do receptor. Os complexos de correguladores são, provavelmente, regulados por modificações pós-traducionais, que apresentam características potencialmente 
distintas e que podem ser exploradas para a modulação de sua atividade em contexto celular ou tecido específico (128).

\subsubsection{Regulação pós-traducional de PPAR $\gamma$}

O PPAR $\gamma$ é regulado por modificações pós-traducionais, dentre as quais incluem a acetilação e a fosforilação (19) (Figura 9).

A desacetilação do PPAR $\gamma$, no TAB, demonstra estar envolvida no recrutamento de adipócitos bege. Esta modificação pós-traducional é resultado da atividade da enzima desacetilase dependente de NAD sirtuína 1 (SIRT1), nas lisinas 268 e 293, e promove a remoção do correpressor NCoR do complexo do PPAR $\gamma$ e o recrutamento do cofator PRDM16 (131), sugerindo possível mecanismo pelo qual ocorre amarronzamento do TAB em resposta à ativação deste $\mathrm{RN}(19,31)$.

As TZD promovem desacetilação do PPAR $\gamma$ e estabilizam a interação entre a PRDM16 e o PPAR $\gamma$, aumentando o tempo de meia vida do fator de transcrição associado ao recrutamento de adipócitos bege no TAB (31). In vivo, a ativação de SIRT1 promove o amarronzamento do TAB e resistência à obesidade (131), o que sugere que os ativadores de SIRT1 possam ter utilidade como agentes promotores de perda de peso (31). Apenas os agonistas totais de PPAR $\gamma$, tais como a rosiglitazona, e não os agonistas parciais, foram descritos como capazes de promover o amarronzamento do TAB via PRDM16 (15). Este achado sugere que a desacetilação do PPAR e interação com a PRDM16 ocorra como resultado da ativação total do RN.

Fosforilação de PPAR $\gamma$ ocorre via proteínas cinases que transferem um grupamento fosfato proveniente de trifosfatos de nucleotídeos para as serinas do PPAR $\gamma$, no caso do PPAR 2 a Ser ${ }^{112}$ ou Ser 273 . O PPAR 2 fosforilado na Ser ${ }^{112}$, localizada na região $A F 1$, por proteínas cinases ativadas por mitogênio (MAP cinases), tem sua atividade transcricional reprimida em razão da inibição da ligação ao ligante e, consequentemente, alteração do recrutamento de cofatores $(132,133)$. A fosforilação do mesmo resíduo de aminoácido por proteínas cinases dependentes de ciclina (Cdk7 e Cdk9) promove o aumento da atividade do PPAR $(136,135)$. 
Assim, a fosforilação do PPAR $\gamma$ em Ser ${ }^{112}$ pode resultar em diferentes padrões de transcrição que dependem do contexto fisiológico e das proteínas cinases envolvidas. (19).

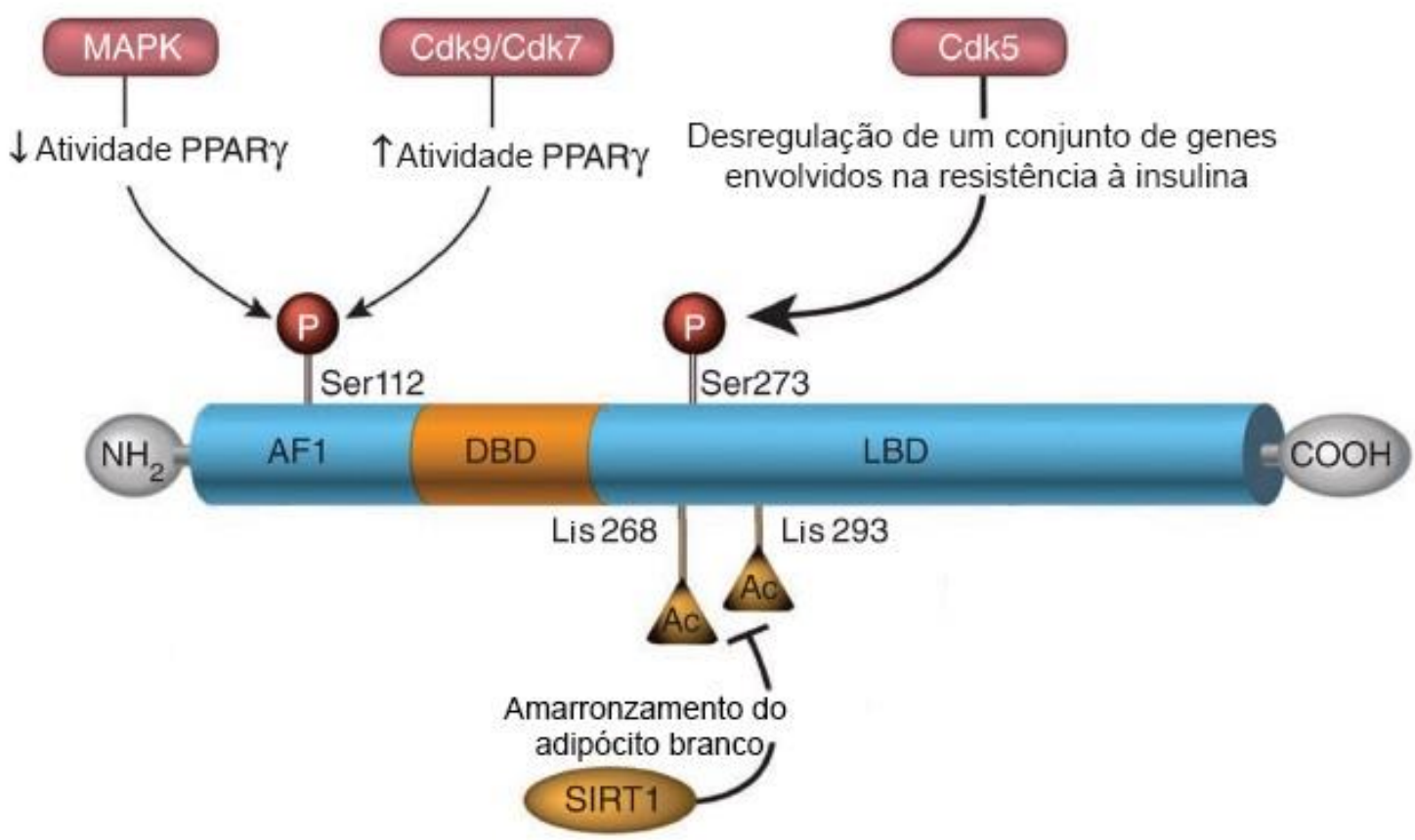

Figura 9 Modificações pós-traducionais do PPAR $\gamma$. Modificações pós-traducionais do PPAR $\gamma$ influenciam a atividade transcricional e a estabilidade da proteína de uma maneira dependente do contexto e da célula. Ac, acetilação; P, fosforilação; SUMO, SUMOilação; Cdk5 / Cdk7 / Cdk9, cinases dependentes de ciclina; MAPK, cinases ativadas por mitogênio; SIRT1, desacetilase dependente de NAD sirtuína 1; Lis, lisina; Ser, serina. Adaptado de (19).

Recentemente, foi demonstrado que a fosforilação do LBD do PPAR $\gamma$ em Ser273 pela proteína cinase Cdk5 não promove modificação geral da atividade transcricional do receptor, porém resulta em mudanças da expressão de genes específicos, como a adiponectina, regulador central da sensibilidade à insulina in vivo, e a adipsina, gene seletivo de células adiposas cuja expressão está primariamente alterada na obesidade (22).

A fosforilação de PPAR $\gamma$ mediada por Cdk5 está relacionada com a obesidade induzida por dieta rica em lipídeos em camundongos (22) e está envolvida na patogênese da resistência à insulina (8). A sinalização pró-inflamatória característica do tecido adiposo obeso provoca a clivagem da proteína p35, cofator de Cdk5, em proteína p25, que se transloca para o núcleo, onde se liga à Cdk5, ativando-a (136). 
A Cdk5, por sua vez, fosforila a $\operatorname{Ser}^{273}$ do PPAR $\gamma$, desregulando a expressão de um subconjunto de genes que codificam reguladores metabólicos fundamentais (22). A fosforilação da Ser ${ }^{273}$ pela Cdk5 é inibida pelas TZD e parece estar intimamente associada aos efeitos antidiabéticos de agonistas do receptor (8).

Estes achados tornam possível o desenvolvimento de novas classe de drogas, tendo como alvo o PPAR $\gamma$, que sejam altamente efetivas e seguras no tratamento da resistência insulínica, por preservar o efeito das TZD em inibir a fosforilação da Ser ${ }^{273}$ do PPAR $\gamma$ e eliminar os efeitos secundários indesejados que ocorrem devido ao agonismo clássico em genes alvo do $\operatorname{PPAR} \gamma(19,85)$.

Agonista de PPAR ideal representaria um composto que se ligasse de forma potente ao receptor sem estimular sua atividade de ativação da transcrição, não induzisse adipogênese, estimulasse a captação de glicose induzida pela insulina e, ainda, bloqueiasse sua fosforilação mediada por Cdk5 (85).

MRL24, um composto sintético não-TZD com atividade agonista fraca em PPAR $\gamma$, se mostrou mais eficaz do que a rosiglitazona no bloqueio da fosforilação de PPAR $\gamma$ mediada por Cdk5 e com excelentes efeitos antidiabéticos (22).

O composto sintético SR1664, desenvolvido em 2011, não possui a atividade de agonismo clássico no PPAR e bloqueia a fosforilação de PPAR $\gamma$ em Ser273 mediada por Cdk5, tanto em cultura de adipócitos quanto em camundongos resistentes à insulina (24). In vivo, tratamento com SR1664 associou-se a ausência de alguns efeitos desfavoráveis das TZD e outros ligantes de PPAR $\gamma$, incluindo retenção hídrica, ganho de peso e comprometimento da formação óssea (24). Tanto SR1664 quanto SR1824, outro composto sintético com as mesmas propriedades, não interagem com a $\mathrm{H} 12$ de nenhuma forma detectável, porém ambos os ligantes promovem aumento da mobilidade da $\mathrm{H} 11$, que distorce a $\mathrm{H} 12$ o suficiente para bloquear o agonismo no PPAR $\gamma(24)$.

Outro composto com atividade agonista parcial que demonstrou inibir a fosforilação de PPAR in vitro foi o GQ16 (23), composto derivado de TZD. In vivo, tratamento com GQ-16 resultou em melhora da sensibilidade insulínica e tolerância à glicose, sem associar-se aos efeitos adversos de ganho de peso e edema característico das TZD. Além disso, reduziu a capacidade adipogênica em cultura de células e in vivo. À semelhança do MRL24, o GQ-16 estabiliza a hélice 3 e regiões 
da folha $\beta$ do LBD do PPAR $\gamma$ mais fortemente que a rosiglitazona, protegendo a região da Ser273 da ação de cinases e, assim, inibindo sua fosforilação (23).

Alguns agonistas parciais não-TZD de PPAR , como o MRL24, nTZDpa, Mbx102 e BVT.13, não apresentaram a capacidade de induzir o amarronzamento do $\mathrm{TAB}$, um efeito potencialmente benéfico no tratamento da obesidade e resistência insulínica (15), enquanto que um agonista parcial derivado de TZD, NC-2000, apresentou capacidade de induzir a expressão do RNAm do gene Ucp1 no tecido adiposo branco visceral (mesentérico) em camundongos KKA $\gamma$ obesos (137).

Dados prévios do Laboratório de Farmacologia Molecular da Universidade de Brasília sugeriram que o GQ-16 induziu aumento da expressão de genes relacionados à termogênese em TAB visceral epididimal em camundongos Swiss com obesidade e resitência à insulina induzidas por dieta hiperlipídica, que poderia explicar, pelo menos em parte, a ausência de indução de ganho de peso em resposta ao tratamento com este composto, quando comparado às TZD (dados submetidos para publicação).

\subsection{GQ-02}

O composto 5-(4-cloro-benzilideno)-3-(4-metil-benzil)-tiazolidina-2,4-diona (GQ-02) (Figura 10) desenvolvido pela Universidade Federal de Pernambuco, foi sintetizado a partir da molécula 5-(benzilideno)-3-(4-metil-benzil)-tiazolidina-2,4diona, com uma substituição na posição 4 do anel benzilideno por uma molécula de cloro (25).

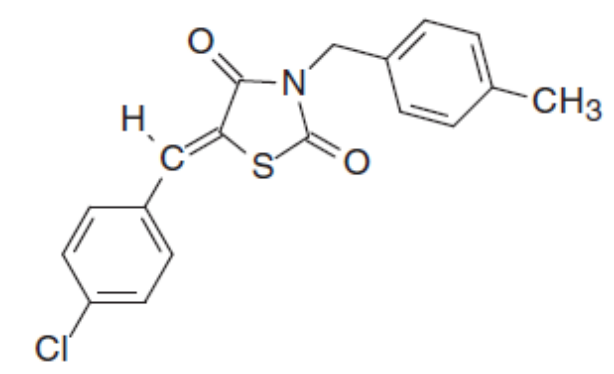

Figura 10 Estrutura química do composto 5-(4-cloro-benzilideno)-3-(4-metil-benzil)-tiazolidina-2,4diona (GQ-02) 
Estudos de "doking" que avaliaram a interação de compostos derivados de 5(benzilideno)-3-(4-metil-benzil)-tiazolidina-2,4-diona com 0 LBD do PPAR $\gamma$ demonstraram que os complexos formados possuem boa estabilidade (energia de ligação negativa), quando comparada à energia de ligação da rosiglitazona (26, 138). O GQ-02 parece interagir com o PPAR $\gamma$ através de ligação de hidrogênio com o resíduo de $\operatorname{Ser}^{289}$ do LBD do PPAR $\gamma$ (26).

Estudo in vivo com camundongos com diabetes induzido por aloxano demonstrou que o tratamento com GQ-02, durante 15 dias, apresenta efeito hipoglicemiante dose-dependente. Resultados semelhantes foram observados quando se analisou o efeito do composto sobre a concentração sérica de triglicerídeos (25). Além disso, o tratamento com GQ-02 associou-se a menor ganho de peso quando comparado ao tratamento com rosiglitazona (25).

Em camundongos Swiss com obesidade e resistência à insulina induzidas por dieta hiperlipídica, foi observado que o tratamento com GQ-02 durante 14 dias resultou em ganho de peso significativamente menor que o observado em resposta ao tratamento, durante o mesmo período, com rosiglitazona. O efeito do GQ-02 e da rosiglitazona em reduzir a glicemia e a massa adiposa visceral foi semelhante. Entretanto, a redução do ganho de peso nos animais tratados com GQ-02 não foi acompanhada de redução do consumo alimentar (26). Estes últimos resultados poderiam sugerir possível efeito do GQ-02 sobre o gasto energético, ou mesmo sobre a perda fecal de energia, variáveis não analisadas no estudo.

O GQ-02 foi investigado também com relação aos seus efeitos cardiovasculares e hepáticos in vivo e comparado à TZD pioglitazona. Camundongos homozigotos para a deleção do gene que codifica o receptor de LDL (LDLR-/-) foram utilizados como modelo de hipercolesterolemia e aterosclerose (139), e induzidos à obesidade por dieta rica em lipídeos. Neste modelo, o tratamento com pioglitazona ou os derivados de TZD GQ-02 e GQ-16 não resultou em melhora do perfil lipídico (139). A TZD pioglitazona não modificou as lesões ateroscleróticas, o GQ-16 promoveu aumento das lesões ateroscleróticas, ao passo que o GQ-02 reverteu estas lesões, o que ficou caracterizado por redução da área das lesões ateroscleróticas e das alterações do endotélio, sugerindo suas propriedades protetoras contra a aterosclerose (139). 
Em estudo posterior envolvendo este mesmo modelo (LDLR-/-) foi observado efeito benéfico do GQ-02 sobre a esteatose hepática e efeito neutro da pioglitazona. No fígado, o GQ-02 diminuiu a vacuolização e infiltração inflamatória, melhorou a organização do parênquima hepático, reduziu o acúmulo lipídico, além de ter apresentado atividade anti-inflamatória (140).

Em conjunto, estes efeitos benéficos em resposta ao tratamento com GQ-02 em modelos in vivo fundamentam o interesse no desenvolvimento de novos estudos com compostos derivados de TZD com perfil de efetividade e segurança mais favorável que o das TZD clássicas. Os efeitos benéficos de sensibilidade à insulina e diminuição de ganho de peso observados com o GQ-02 em relação à TZD rosiglitazona, acompanhados da ausência de alterações do consumo alimentar e redução significativa da massa adiposa visceral (26), sugerem o potencial deste composto em induzir termogênese em depósitos de TAB. Esta possibilidade é reforçada, ainda, pelo efeito de um composto relacionado, o GQ-16, em induzir a expressão de genes relacionados à termogênese em TAB visceral. 


\section{OBJETIVOS}

\subsection{OBJETIVO GERAL}

Investigar efeito do GQ-02, derivado de tiazolidinadionas, sobre variáveis metabólicas in vivo e sobre a aquisição de fenótipo termogênico pelo adipócito in vivo e em cultura.

\subsection{OBJETIVOS ESPECÍFICOS}

- Investigar efeito do GQ-02 sobre a diferenciação de adipócitos em pré-adipócitos 3T3-L1 e em células mesenquimais C3H10T1/2 induzidos a se diferenciar em cultura;

- Investigar efeito do GQ-02 em camundongos machos C57BI/6 alimentados com dieta hiperlipídica sobre as seguintes variáveis:

- Peso corporal e ganho de peso corporal;

- Consumo energético, hídrico e eficiência metabólica;

- Glicemia de jejum;

- Massa adiposa branca visceral epididimal, branca subcutânea inguinal e marrom;

- Massas cardíaca, renal e testicular;

- Consumo de oxigênio do tecido adiposo branco visceral epididimal, branco subcutâneo inguinal e marrom;

- Características histológicas do fígado, tecido adiposo branco visceral epididimal, branco subcutâneo inguinal e marrom;

- Concentração de triglicerídeos no fígado;

- Expressão de gene relacionado à termogênese no tecido adiposo branco visceral epididimal, branco subcutâneo inguinal e marrom. 


\section{MATERIAL E MÉTODOS}

\subsection{MATERIAL}

O GQ-02 foi cedido pelo Prof. Ivan da Rocha Pitta (Universidade Federal de Pernambuco), e a sua síntese se encontra previamente descrita (25). A rosiglitazona foi obtida da Cayman Chemicals (Ann Arbor, MI, EUA), a isobutilmetilxantina, dexametasona, insulina, óleo vermelho O e o tween-20 foram obtidos da Sigma (St. Louis, MO, EUA).

\subsection{CULTURA CELULAR}

Neste estudo, foram utilizados pré-adipócitos 3T3-L1 e células mesenquimais C3H10T1/2 para o ensaio de adipogênese em cultura. Essas células foram cultivadas em meio de cultura DMEM (Dulbecco's Modified Eagle Medium) contendo $2 \mathrm{nM}$ de glutamina, $100 \mathrm{U} / \mathrm{mL}$ de penicilina, $100 \mu \mathrm{g} / \mathrm{mL}$ de estreptomicina e $10 \%$ de soro neonatal bovino, em placas de $150 \mathrm{~mm}$ para cultura de células (Corning®).

As culturas celulares foram mantidas a $37^{\circ} \mathrm{C}$ e $5 \%$ de $\mathrm{CO}_{2}$.

\subsubsection{Ensaio de adipogênese}

O ensaio de adipogênese corresponde à indução da diferenciação em adipócitos a partir de células mantidas em cultura. $O$ primeiro e melhor caracterizado modelo de adipogênese é a linhagem celular 3T3-L1, uma subcepa da linhagem 3T3 do camundongo Swiss, comprometida com o processo de diferenciação em adipócitos (141). As células 3T3-L1 apresentam morfologia de fibroblastos e, quando induzidas com substâncias que ativam a cascata transcricional envolvida na adipogênese, adotam formato arredondado e acúmulo de lipídeos visto como 
gotículas intracelulares, um fenótipo compatível com o do adipócito diferenciado (142). As substâncias capazes de induzir a adipogênese são a isobutilmetilxantina (IBMX), a dexametasona e altas concentrações de insulina, na presença de soro fetal bovino (143).

As células C3H10T1/2 são pertencentes à linhagem de células mesenquimais, isoladas de embriões de camundongos $\mathrm{C} 3 \mathrm{H}$ e, assim como as 3T3L1, também apresentam morfologia de fibroblastos. Funcionalmente, as células C3H10T1/2 são semelhantes à células tronco mesenquimais e, se induzidas por IBMX, dexametasona e insulina, podem diferenciar-se em adipócitos maduros acumulando gotículas lipídicas (144).

Cada componente da combinação dexametasona, IBMX e insulina ativa vias celulares específicas, importantes para a diferenciação adipocitária. A dexametasona ativa o fator de transcrição C/EBP $\beta$, e a IBMX inibe fosfodiesterases de nucleotídeos cíclicos, o que resulta em aumento dos níveis intracelulares de AMPc e ativação do fator de transcrição C/EBPD. O C/EBPß e o C/EBPס, por sua vez, induzem a transcrição do C/EBPa e do PPAR $\gamma$. A insulina contribui para a diferenciação de adipócitos por ativar a expressão de genes específicos desse tipo celular, como o que codifica a síntese de ácidos graxos, a proteína ligadora de ácidos graxos (FABP), a leptina e a adiponectina (87).

Os experimentos foram realizados com ambas as linhagens celulares, préadipócitos 3T3-L1 e células mesenquimais $\mathrm{C} 3 \mathrm{H} 10 \mathrm{~T} 1 / 2$, que foram cultivadas em placas de $150 \mathrm{~mm}$ para cultura de células (Corning®), em meio DMEM contendo soro neonatal bovino a $10 \%$, até sua subconfluência. As células foram plaqueadas em placas de 6 poços até sua confluência e, dois dias após a confluência, foram induzidas a se diferenciar em adipócitos.

As células 3T3-L1 e C3H10T1/2 foram induzidas a se diferenciar em adipócitos com meio completo composto por $0,5 \mathrm{nM}$ de IBMX, $1 \mu \mathrm{g} / \mathrm{mL}$ de insulina e $1 \mu \mathrm{M}$ de dexametasona, por 2 dias. Em seguida, foram mantidas com $1 \mu \mathrm{g} / \mathrm{mL}$ de insulina por 5 dias (3T3-L1) ou 12 dias (C3H10T1/2). Durante o período de indução e manutenção, foram cultivadas em meio DMEM contendo soro fetal bovino a $10 \% \mathrm{e}$ submetidas a tratamentos com veículo (DMSO, controle negativo), rosiglitazona $10^{-5}$ $\mathrm{M}$ (controle positivo) ou GQ-02 $10^{-5} \mathrm{M}$.

A mistura dexametasona, IBMX e insulina constitui um forte indutor de adipogênese para as células 3T3-L1, já comprometidas com a diferenciação 
adipocitária (145). Estas células foram induzidas a se diferenciar também com tratamento apenas com insulina. O meio indutor contendo insulina, mas não IBMX e dexametasona, é considerado um indutor menos acentuado da diferenciação adipocitária.

Pré-adipócitos 3T3-L1 foram induzidos a se diferenciar em adipócitos com a utilização de insulina ( $10 \mu \mathrm{g} / \mathrm{mL}$ ), por 2 dias, e mantidos em meio contendo insulina a $5 \mu \mathrm{g} / \mathrm{mL}$ por 8 dias. Durante o período de indução e manutenção, foram cultivadas em meio DMEM contendo soro fetal bovino a $10 \%$ e submetidas a tratamentos com veículo (DMSO, controle negativo), rosiglitazona $10^{-5} \mathrm{M}$ (controle positivo) ou GQ-02 $10^{-5} \mathrm{M}$.

Ao final do ensaio de diferenciação de adipócitos, a adipogênese foi analisada pelo acúmulo lipídico intracelular das células 3T3-L1 e C3H10T1/2 por meio de coloração com óleo vermelho $\mathrm{O}$. Foram realizados 3 ensaios de diferenciação de adipócitos independentes com cada uma das linhagens celulares.

\subsubsection{Coloração com óleo vermelho 0}

Após o ensaio de diferenciação de adipócitos das células 3T3-L1 e C3H10T1/2, o meio de cultura das células foi descartado e essas foram lavadas com PBS (Phosphate-Buffered Saline) por duas vezes. Posteriormente, foram fixadas com formaldeído a 4\% (v/v) em PBS por 40 minutos e, logo em seguida, feitas 2 lavagens com água destilada e 2 lavagens com PBS. Foi adicionado isopropanol $60 \%(\mathrm{v} / \mathrm{v})$ em água destilada por 5 minutos e, em seguida, as células foram incubadas com o corante para lipídeos óleo vermelho O (Oil Red O), previamente solubilizado e filtrado, durante uma hora. Ao término do processo as células foram lavadas com água destilada para a retirada do excesso do corante e as imagens foram fotodocumentadas no microscópio Regular Inverted BF\&Fluorescent Microscope, com aumento de 10 vezes. 


\subsection{MODELO ANIMAL}

Foram utilizados camundongos C57BL/6 machos isogênicos, obtidos do Centro de Bioterismo, da Faculdade de Medicina da Universidade de São Paulo.

Durante o estudo os camundongos foram mantidos em gaiolas apropriadas (micro isolador em estante ventilada - Alesco, SP, Brasil), individualizados, em ambiente com temperatura controlada $\left(25^{\circ} \mathrm{C}\right)$ e ciclo claro/escuro a cada 12 horas (escuro entre 18 h e 6 h). 0 acesso à alimentação e água foi livre (ad libitum).

\subsubsection{Considerações éticas}

Os procedimentos realizados estão de acordo com as recomendações do Conselho Nacional de Controle de Experimentação Animal (CONCEA), seguindo a Diretriz Brasileira para o Cuidado e a Utilização de Animais para fins Científicos e Didáticos (146). O projeto foi avaliado e aprovado pela Comissão de Ética no Uso de Animais da Universidade de Brasília, UnBDoc no 141753/2013 (Anexo I).

A eutanásia seguiu as Diretrizes da Prática de Eutanásia, do CONCEA (147) e o Guia Brasileiro para Boas Prática para Eutanásia em Animais, do Conselho Federal de Medicina Veterinária (148). Após a eutanásia, as carcaças dos animais foram descartadas seguindo a Lei Nacional de Resíduos Sólidos № 12.305/2010 (149).

\subsubsection{Delineamento experimental}

Os animais foram divididos aleatoriamente em grupos de 4 a 5 animais. Um grupo de animais foi alimentado com dieta controle contendo baixa quantidade de lipídeos (DC, 10\% do total de kcal representados por lipídeos) e os demais grupos, com dieta hiperlipídica (DHL, 60\% do total de kcal representados por lipídeos), da $5^{\text {a }}$ à $20^{\mathrm{a}}$ semanas de vida. A DHL teve como objetivo induzir obesidade e hiperglicemia. 
As dietas foram obtidas da empresa Research Diets (New Brunswick, EUA), cuja descrição da composição encontra-se apresentada no quadro 2, e foram fornecidas aos animais na forma de pellet.

Quadro 2 - Descrição dos componentes das dietas controle e hiperlipídica

\begin{tabular}{|c|c|c|c|c|}
\hline & $\begin{array}{r}\text { Dieta } \\
\text { (D1 }\end{array}$ & $\begin{array}{l}\text { ntrole } \\
\text { OB) }\end{array}$ & $\begin{array}{r}\text { Dieta I } \\
\text { ([ }\end{array}$ & $\begin{array}{l}\text { rlipídica } \\
\text { 492) }\end{array}$ \\
\hline & g (\%) & kcal (\%) & g (\%) & kcal (\%) \\
\hline Proteína & 19,2 & 20 & 26 & 20 \\
\hline Carboidrato & 67,3 & 70 & 26 & 20 \\
\hline Lipídeo & 4,3 & 10 & 35 & 60 \\
\hline Total & & 100 & & 100 \\
\hline$(\mathrm{kcal} / \mathrm{g})$ & 3,85 & & 5,24 & \\
\hline Ingrediente & $\mathbf{g}$ & kcal & $\mathbf{g}$ & kcal \\
\hline Caseína & 200 & 800 & 200 & 800 \\
\hline L-cistina & 3 & 12 & 3 & 12 \\
\hline Amido de milho & 315 & 1260 & 0 & 0 \\
\hline Maltodextrina & 35 & 140 & 125 & 500 \\
\hline Sacarose & 350 & 1400 & 68,8 & 275 \\
\hline Celulose & 50 & 0 & 50 & 0 \\
\hline Óleo de soja & 25 & 225 & 25 & 225 \\
\hline Banha de porco & 20 & 180 & 245 & 2205 \\
\hline Mistura mineral S10026 & 10 & 0 & 10 & 0 \\
\hline Fosfato dicálcio & 13 & 0 & 13 & 0 \\
\hline Carbonato de cálcio & 5,5 & 0 & 5,5 & 0 \\
\hline Citrato de potássio & 16,5 & 0 & 16,5 & 0 \\
\hline Mistura de vitamina V10001 & 10 & 40 & 10 & 40 \\
\hline Bitartrato de colina & 2 & 0 & 2 & 0 \\
\hline Corante amarelo & 0,05 & 0 & - & - \\
\hline Corante azul & - & - & 0,05 & 0 \\
\hline Total & 1055,05 & 4057 & 773,85 & 4057 \\
\hline
\end{tabular}

Após a 16 a semana de vida, os camundongos alimentados com DHL foram subdivididos aleatoriamente em 3 grupos contendo 4 a 5 camundongos cada. Estes grupos foram tratados, diariamente, durante 21 dias (entre a $17^{\underline{a}}$ e a $20^{\underline{a}}$ semanas de 
vida), com GQ-02 (20 mg/kg/dia), rosiglitazona (4 mg/kg/dia, controle positivo) ou veículo (solução de tween-20 a 0,25\% em solução fisiológica, v/v, controle negativo), via injeção intraperitoneal.

Desta forma, foram compostos os seguintes grupos de tratamento:

Grupo 1: Dieta controle, tratamento com veículo.

Grupo 2: DHL, tratamento com veículo.

Grupo 3: DHL, tratamento com rosiglitazona (4 mg/kg/dia).

Grupo 4: DHL, tratamento com GQ-02 (20 mg/kg/dia).

\subsubsection{Procedimentos}

Entre a $5^{\mathrm{a}}$ e a $16^{\mathrm{a}}$ semanas de vida, o peso corporal $(\mathrm{g})$, energia ingerida $(\mathrm{kJ})$ e ingestão hídrica $(\mathrm{mL})$ foram avaliados três vezes por semana. Durante o período do tratamento, da $17^{\text {a }}$ à $20^{\text {a }}$ semanas de vida, estas variáveis foram avaliadas diariamente. A partir desses dados, as seguintes variáveis foram calculadas:

- Ganho de peso corporal durante o tratamento (peso ao final do tratamento menos o peso no dia de início do tratamento, em g).

- Ingestão hídrica durante o tratamento (média do consumo diário, em mL, de água durante o tratamento).

- Energia ingerida durante o tratamento (energia ingerida durante os 21 dias do tratamento, considerando a quantidade de energia, em kJ, por g de dieta).

- Eficiência metabólica (ganho de peso em g dividido pela energia ingerida em $\mathrm{kJ})$.

- Peso dos tecidos adiposos branco visceral (epididimal), branco subcutâneo (inguinal), tecido adiposo marrom (interescapular), coração, rins e testículos (peso dos tecidos normalizados para o peso total dos camundongos, em mg/g).

A glicemia foi aferida no período da manhã, após jejum noturno de 12 horas, na $16^{\underline{a}}$ e na $20^{\underline{a}}$ semanas de vida, com a utilização de tiras reativas (Accuchek 
Performa, Roche, USA) e com uso de glicosímetro (Accuchek Performa, Roche, USA) com limite de detecção entre 10 e 600 mg/dL.

Ao final do estudo, os animais foram eutanasiados e foram dissecados os depósitos de tecido adiposo branco visceral (epididimal), tecido adiposo branco subcutâneo (inguinal) e tecido adiposo marrom (interescapular), além do fígado, coração, rins e testículos. Depois desse procedimento, suas massas foram aferidas. Os tecidos foram congelados em nitrogênio líquido e armazenados a $-80^{\circ} \mathrm{C}$ para avaliação da expressão de RNA mensageiro (RNAm) dos genes de interesse. Fragmentos desses tecidos foram fixados em paraformaldeído $4 \%$ e embebidos em parafina para posterior análise histológica com coloração com hematoxilina e eosina. Outros fragmentos dos diferentes depósitos de tecido adiposo foram mantidos em PBS para avaliação da taxa de respiração do tecido.

\subsection{ENSAIO DE RESPIRAÇÃO}

Foram coletados, durante a eutanásia, amostras de tecido adiposo branco visceral epididimal, tecido adiposo branco subcutâneo inguinal e tecido adiposo marrom interescapular frescos para mensurar a taxa de respiração celular. Para isso, foi utilizado o aparelho Mitocell MT200 respirometer (Strathkelvin instruments limited, North Lanarkshire, Scotland), conforme previamente descrito $(17,150)$ com adaptações.

Dois fragmentos de aproximadamente 30 a $80 \mathrm{mg}$ dos depósitos de tecido adiposo branco foram coletados de cada animal. Do tecido adiposo marrom interescapular, foram coletados dois fragmentos de aproximadamente 10 a $30 \mathrm{mg}$. Os tecidos foram pesados e, em seguida, cortados em fragmentos menores rapidamente, com auxílio de tesoura.

O tecido foi transferido para o interior da câmara de respiração já contendo o tampão de respiração pré-aquecido a $3^{\circ}$ ㅇ. A câmara foi fechada e o consumo do oxigênio mensurado por 1 e 5 minutos, em $\mu \mathrm{mol} / \mathrm{L}$.

O tampão de respiração foi mantido pré-aquecido em banho-maria a $37^{\circ} \mathrm{C}$ para estabilização da temperatura e consiste em DPBS 1x (Dulbecco's phosphate- 
buffer saline), $2 \%$ de albumina de soro bovino, $25 \mathrm{mM}$ de glicose e $1 \mathrm{mM}$ de piruvato de sódio.

Cada tecido foi analisado em duplicata e os valores do consumo de $\mathrm{O}_{2}$, em $\mu \mathrm{g}$, foram normalizados para o tempo, em minutos, e o peso do tecido, em $\mathrm{mg}$.

\subsection{HISTOLOGIA}

\subsubsection{Fixação de tecidos}

Fragmentos de tecido adiposo branco visceral epididimal, tecido adiposo branco subcutâneo inguinal e tecido adiposo marrom interescapular coletados durante a eutanásia foram imediatamente armazenados em solução fixadora de paraformaldeído 4\% (v/v) em PBS até o seu processamento.

Fragmentos de fígado coletados foram mantidos no paraformaldeído $4 \%$ por 24 horas e então transferidos para outra solução fixadora, solução de Bouin $(75 \mathrm{~mL}$ de ácido pícrico, $25 \mathrm{~mL}$ de formol e $5 \mathrm{~mL}$ de ácido acético) por $4 \mathrm{~h}$, lavados várias vezes em solução de álcool etílico $50 \%$ (v/v) e depois conservados em álcool etílico $70 \%(v / v)$ até o seu processamento.

\subsubsection{Desidratação e inclusão em parafina}

Para a realização do processo de desidratação, os fragmentos de tecido adiposo foram transferidos para cassetes tradicionais de histologia e submetidos a consecutivos banhos em concentrações progressivas de álcool como descrito a seguir.

- 1 hora em álcool 30\% (v/v);

- 1 hora em álcool 50\% (v/v);

- 1 hora em álcool 70\% (v/v);

- 1 hora em álcool 80\% (v/v); 
- 1 hora em álcool 90\% (v/v);

- 1 hora em álcool absoluto, 2 vezes.

Os fragmentos de fígado mantidos no álcool etílico $70 \%$ foram transferidos para cassetes tradicionais de histologia e realizada a desidratação em álcoois em concentrações progressivas de 1 hora em cada álcool, como descrito, a partir do álcool $80 \%(\mathrm{v} / \mathrm{v})$.

Após a desidratação, os tecidos passam pela diafanização por imersão em solução de álcool absoluto e tolueno ( $\mathrm{v} / \mathrm{v})$ por 1 hora, seguido por dois banhos de 1 hora em tolueno absoluto, um banho de 30 minutos em solução de tolueno e parafina a $60^{\circ} \mathrm{C}(\mathrm{v} / \mathrm{v})$ e, por último, 3 banhos de uma hora em parafina (Paraplast, Leica Biosystems, Alemanha) fundida em estufa a $60^{\circ} \mathrm{C}$.

Os cortes de tecidos foram então fixados na parafina em moldes na posição vertical e no fundo da forma, com o auxílio de pinça pré-aquecida. O material parafinizado foi mantido em temperatura ambiente até a realização de cortes de tecido no micrótomo (Rotary microtome, modelo RM2125, Leica Biosystems, Alemanha).

\subsubsection{Corte no micrótomo}

Os tecidos incluídos em blocos de parafina permaneceram 30 minutos a $20^{\circ} \mathrm{C}$ antes da microtomia, para evitar possível enrugamento do tecido durante o corte.

Os blocos com os fragmentos de fígado e tecido adiposo foram cortados em micrótomo com espessuras, respectivamente, de 5 e $7 \mu \mathrm{m}$. Os fragmentos obtidos foram transferidos para banho-maria $\left(40^{\circ} \mathrm{C}\right)$, distendidos com o auxílio de pinça e aderidos em lâminas histológicas. As lâminas foram armazenadas em temperatura ambiente até a coloração. 


\subsubsection{Coloração com hematoxilina-eosina}

As lâminas foram coradas com hematoxilina-eosina. Para a realização desta etapa, as lâminas foram transferidas para estufa a $60^{\circ} \mathrm{C}$ por aproximadamente 30 minutos para a desparafinização e imersas em consecutivos banhos de rehidratação, como descritos a seguir.

- 3 banhos em xilol, por 2 minutos;

- 3 banhos em álcool etílico absoluto, por 2 minutos;

- 1 banho em álcool etílico 95\%, por 2 minutos;

- 1 banho em álcool etílico 80\%, por 2 minutos;

- 1 banho em álcool etílico 70\%, por 2 minutos;

- 1 banho em álcool etílico 50\%, por 2 minutos;

- Lavadas em água corrente, por 3 minutos;

- Lavadas em água destilada;

- Imersas em solução de hematoxilina de Harris (5 mg hematoxilina, $50 \mathrm{~mL}$ de álcool absoluto, $100 \mathrm{mg}$ de alúmen de potássio, 2,5 g de óxido vermelho de mercúrio, $1000 \mathrm{~mL}$ de água destilada) por 2 minutos, para as amostras de fígado, e 5 minutos para as de tecido adiposo.

Posteriormente as lâminas foram lavadas em água corrente para retirada do excesso de hematoxilina, mergulhadas em água destilada e imersas rapidamente em álcool ácido (ácido clorídrico 1\% em álcool 70\%) e novamente lavadas em água destilada, seguindo para a coloração por eosina.

Para imersão em eosina, as lâminas foram inicialmente imersas em solução Scott (Leica Biosystems, Alemanha), lavadas em água corrente e em seguida em água destilada, foi retirado o excesso de água destilada e então as lâminas foram imersas em eosina alcoólica 1\% por 1 minuto, para amostras de fígado. Em seguida, as lâminas foram imersas em 3 banhos de 1 minuto em álcool etílico 95\% (v/v) e 6 banhos de 1 minuto em álcool etílico absoluto. Para finalização do processo de coloração, as lâminas foram imersas em 3 banhos de 1 minuto em xilol.

No tecido adiposo, a eosina utilizada foi eosina aquosa $1 \%$ com 0,05 $\mathrm{mg}$ de ácido fosfotúngstico, realizado 1 banho de 5 minutos e então as lâminas foram lavadas em água destilada, secas em temperatura ambiente e realizada a montagem das lâminas. 
Para a montagem das lâminas, foi usado meio sintético Entellan (Entellan new, Sigma-Aldrich, St. Louis, USA) e lamínula para finalização.

A análise histológica foi realizada por imagens dos cortes dos tecidos capturadas por câmera digital acoplada a um microscópio de luz (Axio imager A1, Zeiss Inc., Jena, Alemanha), com aumento de 10 vezes.

\subsection{QUANTIFICAÇÃO DE TRIGLICERÍDEOS HEPÁTICOS}

O teor de triglicerídeos hepático foi quantificado como descrito anteriormente (151), com adaptações. Amostras do fígado de aproximadamente 100mg congeladas foram homogeneizados em solução de 2:1:0,8 de clorofórmio:metanol:PBS e, em seguida, centrifugadas. A camada orgânica foi removida e o conteúdo de triglicerídeos foi mensurada pelo método enzimático usando kit comercial (OSR60118, Beckman Coulter, Inc., Brea, EUA).

\subsection{ANÁLISE DA EXPRESSÃO GÊNICA}

\subsubsection{Isolamento de RNA total}

RNA total foi extraído das amostras de tecido adiposo branco visceral epididimal, branco subcutâneo inguinal e tecido adiposo marrom interescapular.

As amostras de tecido foram descongeladas e imediatamente homogeneizadas em tubos cônicos de $15 \mathrm{~mL}$ com reagente TRIzol (Invitrogen, Life Technologies), na proporção de 0,1g de tecido por $\mathrm{mL}$ de TRIzol, com a utilização de um homogeneizador de tecidos. As amostras foram então incubadas a temperatura ambiente por 5 minutos e, em seguida, centrifugadas a 14000 rpm, durante 10 minutos, a $4^{\circ} \mathrm{C}$, com formação de pellet de debris celulares. Apenas para as amostras de tecido adiposo branco, ocorre a formação de fina camada de gordura 
na parte superior do tubo que foi descartada e as amostras centrifugadas novamente.

O sobrenadante foi então transferido para microtubos de $1,5 \mathrm{~mL}$ e o pellet descartado. Foram adicionados $200 \mu \mathrm{L}$ de clorofórmio por $\mathrm{mL}$ de TRIzol utilizado na etapa de homogeneização. Os tubos foram agitados em vórtex durante 15 segundos, incubados a temperatura ambiente por 3 minutos e centrifugados a 14 0000 rpm, durante 15 minutos, a 4ํㅡ. Houve a formação de três fases, fase inferior de coloração vermelha, que contém o DNA; fase intermediária de coloração branca, contendo proteínas; e fase superior incolor, que contém o RNA. Apenas a fase superior (aquosa) que contém o RNA foi transferida para outro microtubo de 1,5 mL onde foram adicionados $500 \mu \mathrm{L}$ de isopropanol absoluto (por $\mathrm{mL}$ de TRIzol utilizado na etapa de homogeneização). Os tubos foram agitados em vórtex, incubados durante 10 minutos a temperatura ambiente e centrifugados a 14000 rpm, durante 10 minutos, a $4^{\circ} \mathrm{C}$, com formação de pellet de RNA. O sobrenadante foi descartado e ao pellet foi adicionado $1 \mathrm{~mL}$ de etanol $75 \%(\mathrm{v} / \mathrm{v})$ gelado. Os tubos foram agitados em vórtex e centrifugados a $9000 \mathrm{rpm}$, durante 5 minutos, a $4^{\circ} \mathrm{C}$. O sobrenadante foi descartado e os tubos vertidos sobre gaze estéril para secagem do pellet. O pellet foi então ressuspendido em volumes de 20 - $50 \mu \mathrm{L}$ de água MilliQ tratada com dietilpirocarbonato 0,1\% (DEPC 0,1\%) (Sigma-Aldrich, St Louis, MO, EUA) e as amostras mantidas a $-80^{\circ} \mathrm{C}$ até sua utilização.

\subsubsection{Quantificação do RNA total e determinação da pureza da amostra}

A concentração de RNA total nas amostras foi determinada no espectrofotômetro de microvolume NanoDrop 2000/2000c (Thermo Fisher Scientific, Wilmington, Delaware USA), utilizando-se $1 \mu \mathrm{L}$ da amostra.

A concentração de RNA total é fornecida automaticamente pelo equipamento em $\mu \mathrm{g} / \mu \mathrm{L}$, determinada pelo seguinte cálculo: (DO $260 \mathrm{~nm} \times$ 40) / 1000, em que DO 260 representa o valor da densidade óptica da amostra determinada no comprimento de onda $260 \mathrm{~nm}$. O grau de pureza da amostra, também fornecido automaticamente pelo equipamento, é calculado pela razão entre as densidades ópticas nos comprimentos de onda 260 e $280 \mathrm{~nm}$. Consideraram-se satisfatórias as 
amostras que demonstraram grau de pureza entre 1,7 e 2,0, visto que estes valores representam baixa contaminação da amostra com proteínas.

\subsubsection{Tratamento do RNA com enzima DNAse}

Com a finalidade de evitar possibilidade de contaminação com DNA genômico e consequente influência sobre a avaliação da expressão gênica, as amostras de RNA total foram tratadas com enzima desoxirribonuclease (DNAse) (Sigma-Aldrich, St Louis, MO, EUA) durante 15 minutos, a temperatura ambiente e de acordo com o protocolo do fabricante.

\subsubsection{PCR quantitativa em tempo real}

A transcrição reversa e amplificação do cDNA foram realizadas a partir do RNA total extraído das amostras, em único passo, por PCR quantitativa em tempo real utilizando o kit Power SYBR® Green RNA-to-CT 1-Step (Applied Biosystems, Foster City, CA, EUA). O produto de amplificação de cada amostra foi analisado pelo fluoróforo SYBR® Green. Os fluoróforos se intercalam na fita dupla de DNA e, ao serem excitados por luz, emitem fluorescência cujo intensidade é proporcional à quantidade do produto de amplificação. A fluorescência detectada é representada por meio do Ct (ciclo limiar, cycle threshold), que representa o ciclo na reação de amplificação a partir do qual a amplificação se torna exponencial.

As reações foram preparadas em placas de 96 poços (MicroAmp Optical, Applied Biosystems), em triplicatas, para volume final de $10 \mu \mathrm{L}$, de acordo com instruções do fabricante. Uma reação controle negativo, ou seja, sem amostra de RNA total, foi realizada para cada par de primers a fim de se verificarem possíveis contaminações.

As reações foram conduzidas por termociclador AB7500 (Applied Biosystems, Foster City, CA, EUA). As sequências dos iniciadores ou primers utilizados estão descritas no quadro 3. 
Quadro 3 - Sequência dos primers utilizados para determinação da expressão gênica por PCR quantitativa em tempo real

\begin{tabular}{|c|l|l|}
\hline Primer $^{1}$ & Proteína correspondente & \multicolumn{1}{|c|}{ Sequência } \\
\hline Ucp1 & $\begin{array}{l}\text { Proteína desacopladora } \\
\text { tipo 1 (UCP1) }\end{array}$ & F: 5'-ACTGCCACACCTCCAGTCATT-3' \\
& R: 5'-CTTTGCCTCACTCAGGATTGG-3' \\
\hline Gapdh & $\begin{array}{l}\text { Gliceraldeído 3-fosfato } \\
\text { desidrogenase (GAPDH) }\end{array}$ & F: 5'-AAGGGCTCATGACCACAGTC-3' \\
& R: 5'-CAGGGATGATGTTCTGGGCA-3' \\
\hline
\end{tabular}

${ }_{1}^{1}$ Identificação do primer pelo gene correspondente; F: primer forward; R: primer reverse

As condições de termociclagem durante a PCR foram:

- Programa de transcrição reversa: $48^{\circ} \mathrm{C}$ durante 30 minutos;

- Ativação da Taq DNA polimerase: $95^{\circ} \mathrm{C}$ durante 10 minutos;

- Quarenta ciclos de desnaturação (95ํㅡ durante 15 segundos) e anelamento e amplificação ( $60^{\circ} \mathrm{C}$ durante 1 minuto);

- Curvas de dissociação (programa de dissociação do produto de amplificação) realizado após cada reação com o objetivo de se verificar sua especificidade, confirmando a ausência de formação de dímeros de primers e/ou de produtos inespecíficos de amplificação. Para isso, as amostras foram submetidas a aumentos gradativos de temperatura (acréscimos de $0,3^{\circ} \mathrm{C}$ ) de $60^{\circ} \mathrm{C}$ para $95^{\circ} \mathrm{C}$. À medida que a temperatura aumenta, a fluorescência decresce. $O$ ponto correspondente ao decaimento mais acelerado do sinal de fluorescência é denominado de temperatura de dissociação Tm (melting temperature) e determina o momento em que o produto de PCR apresenta-se $50 \%$ em fita dupla e $50 \%$ em fita simples. A Tm é específica para cada sequência de DNA amplificada e, assim, espera-se que apenas um pico de decaimento seja detectado para cada par de primers utilizado.

A expressão relativa do RNAm para cada um dos genes alvo foi determinada pelo método comparativo $\Delta \Delta \mathrm{Ct}$, com normalização para o gene de referência que codifica a gliceraldeído 3-fosfato desidrogenase (Gapdh). Para isso, os valores de $\mathrm{Ct}$ obtidos para cada amostra nas reações de amplificação dos genes alvo (cuja 
expressão se objetivou quantificar) foram subtraídos do valor do Ct obtido para as mesmas amostras nas reações de amplificação do gene referência (Gapdh), sendo obtido o $\Delta \mathrm{Ct}$.

$$
\Delta \mathrm{Ct}=\mathrm{Ct} \text { gene alvo }-\mathrm{Ct} \text { gene referência }
$$

A quantificação relativa de cada gene alvo foi obtida por meio do método de comparação de Ct ou $\Delta \Delta \mathrm{Ct}$. Segundo este método, a expressão relativa do gene alvo corresponde ao valor obtido pela fórmula aritmética $2^{-\Delta \Delta C t}$, em que

$$
\Delta \Delta \mathrm{Ct}=\Delta \mathrm{Ct} \text { intervenção }-\Delta \mathrm{Ct} \text { calibrador }
$$

Para as amostras de tecidos animais analisadas, a intervenção corresponde às amostras de camundongos alimentados com DHL e tratados com RSG ou GQ-02, e o calibrador corresponde às amostras de tecidos originadas de animais alimentados com DHL e tratados com veículo.

\subsection{ANÁLISE ESTATÍSTICA}

Os dados foram analisados no programa estatístico Graph Pad Prism 5.0. Todos os resultados foram expressos como média \pm erro padrão da média (EPM). teste $\mathrm{t}$ de Student não pareado foi utilizado para comparar a média entre dois grupos; a análise de variância de um fator (one way ANOVA) seguida do pós-teste de Newman-Keuls foi utilizada para comparar as médias entre múltiplos grupos; e a análise de variância de dois fatores (two-way ANOVA) seguida do pós-teste de Bonferroni foi utilizada para comparar as médias entre múltiplos grupos com relação tratamento ao longo do tempo.

A expressão relativa do RNAm foi analisada utilizando o teste nãoparamétrico Kruskal-Wallis seguido pelo pós-teste Dunn. O nível de significância adotado foi $p<0,05$. 


\section{RESULTADOS}

\subsection{CULTURA CELULAR}

\subsubsection{Efeito do GQ-02 sobre a adipogênese}

Pré-adipócitos 3T3-L1 e células mesenquimais C3H10T1/2 foram induzidos a se diferenciar com meio completo contendo combinação de IBMX, dexametasona e insulina em placas de 6 poços por 7 e 14 dias, respectivamente. Durante todo o período de diferenciação, as células foram tratadas com veículo (DMSO, controle negativo), rosiglitazona $\left(10^{-5} \mathrm{M}\right.$, controle positivo) ou GQ-02 $\left(10^{-5} \mathrm{M}\right)$. Ao final dos 7 (células 3T3-L1) e 14 dias (células C3H10T1/2), a diferenciação foi avaliada pela coloração com óleo vermelho $O$.

Foi observado aumento do acúmulo intracelular de lipídeos, indicativo de diferenciação adipocitária, nas células 3T3-L1 e mesenquimais C3H10T1/2 com tratamento com rosiglitazona $10^{-5} \mathrm{M}$, controle positivo da indução da adipogênese, em relação às células tratadas com o veículo DMSO (Figuras 11 e 12).

Nas células 3T3-L1 induzidas a se diferenciar em adipócitos com meio contendo IBMX, dexametasona e insulina e tratadas com GQ-02, foi observado aumento da diferenciação adipocitária avaliado pelo acúmulo intracelular de lipídeos corados com óleo vermelho $\mathrm{O}$ em relação às células tratadas com DMSO. $\mathrm{O}$ acúmulo lipídico observado foi reduzido em relação às células tratadas com rosiglitazona (Figura 11$)$. 


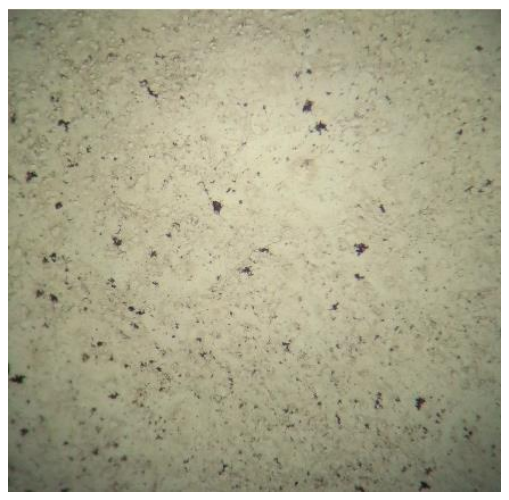

1. Não diferenciado

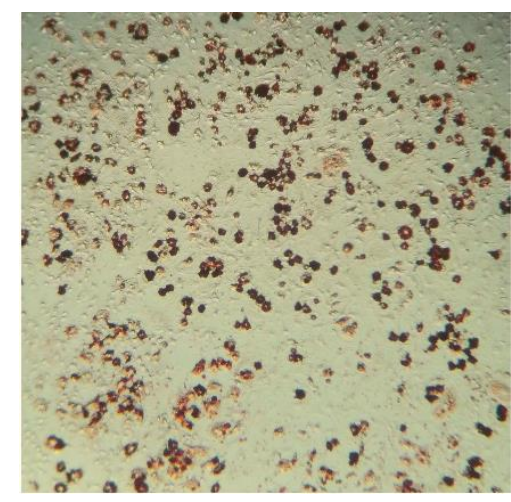

2. DMSO

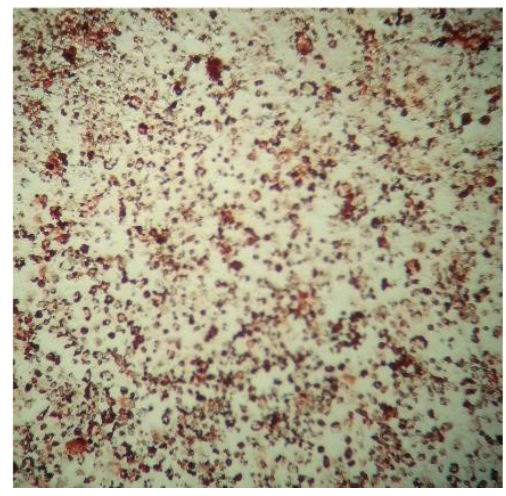

3. Rosiglitazona $10^{-5} \mathrm{M}$

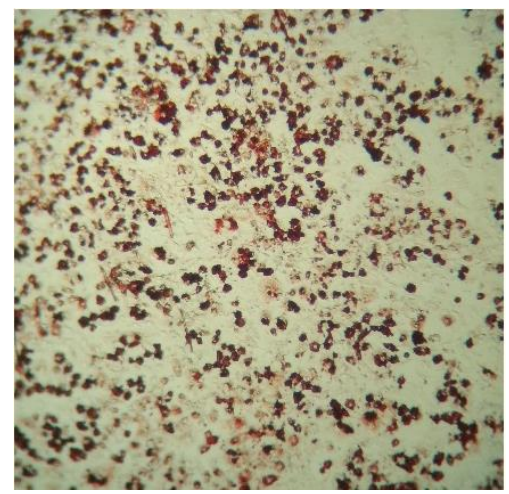

4. GQ-02 $10^{-5} \mathrm{M}$

Figura 11 Efeito do GQ-02 sobre a adipogênese em pré-adipócitos 3T3-L1 induzidos com meio completo. Pré-adipócitos 3T3-L1 induzidos a se diferenciar em adipócitos com meio contendo $1 \mu \mathrm{M}$ de dexametasona, 0,5 nM de IBMX e $1 \mu \mathrm{g} / \mathrm{mL}$ de insulina por dois dias e, em seguida, mantidos em meio contendo $1 \mu \mathrm{g} / \mathrm{mL}$ de insulina. Durante o período de cultivo (7 dias), foram tratados com veículo (DMSO), rosiglitazona $\left(10^{-5} \mathrm{M}\right)$ ou GQ-02 $\left(10^{-5} \mathrm{M}\right)$. Após 7 dias, foram corados com óleo vermelho $\mathrm{O}$ e observados por microscopia. Aumento de 10x. 
Nas células mesenquimais C3H10T1/2 induzidas a se diferenciar em adipócitos em presença do GQ-02, não foi observado aumento do acúmulo lipídico intracelular quando comparadas ao grupo controle tratado com DMSO (Figura 12).

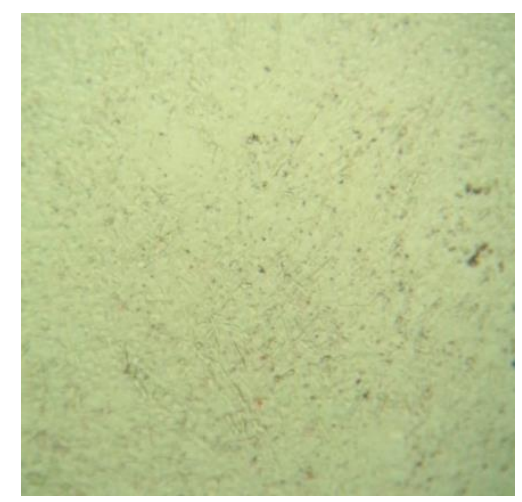

1. Não diferenciado

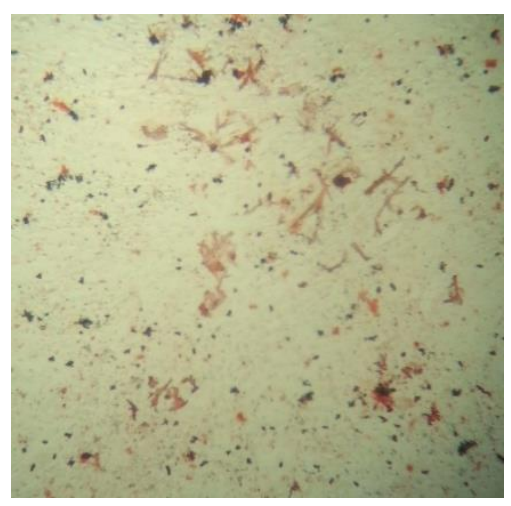

2. DMSO

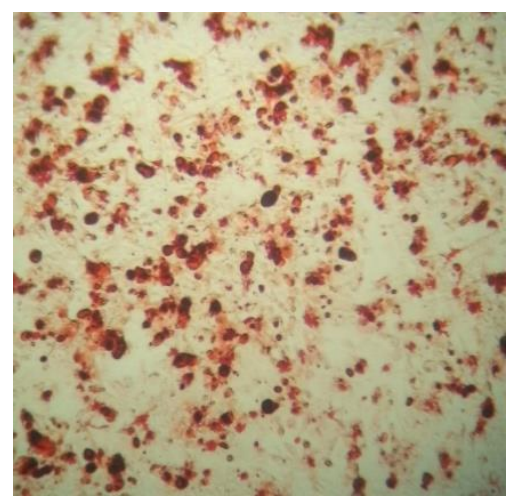

3. Rosiglitazona $10^{-5} \mathrm{M}$

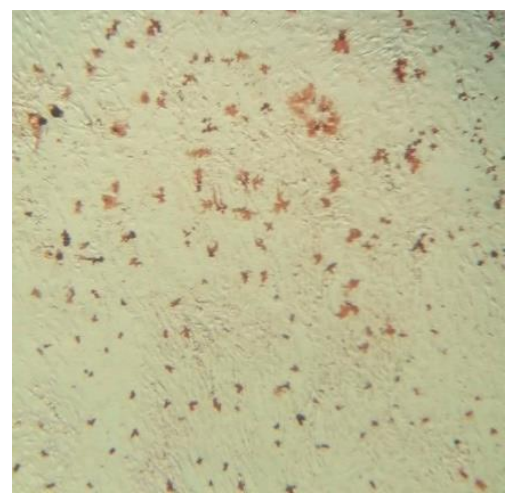

4. GQ-02 $10^{-5} \mathrm{M}$

Figura 12 Efeito do GQ-02 sobre a adipogênese em células mesenquimais C3H10T1/2 induzidas com meio completo. Células mesenquimais $\mathrm{C} 3 \mathrm{H} 10 \mathrm{~T} 1 / 2$ induzidas a se diferenciar em adipócitos com meio contendo $1 \mu \mathrm{M}$ de dexametasona, 0,5 nM de IBMX e $1 \mu \mathrm{g} / \mathrm{mL}$ de insulina por dois dias e, em seguida, mantidas em meio contendo $1 \mu \mathrm{g} / \mathrm{mL}$ de insulina. Durante o período de cultivo (14 dias), foram tratadas com veículo (DMSO), rosiglitazona $\left(10^{-5} \mathrm{M}\right)$ ou GQ-02 $\left(10^{-5} \mathrm{M}\right)$. Após 14 dias, foram coradas com óleo vermelho $\mathrm{O}$ e observadas por microscopia. Aumento de 10x.

A indução da diferenciação das células 3T3-L1 em adipócitos pela combinação IBMX, dexametasona e insulina é considerada um potente estímulo à adipogênese em cultura (152). Para testar o efeito do GQ-02 em condições menos potentes de indução de adipogênese, e possivelmente mais consistentes com as do ambiente extracelular in vivo (144), os pré-adipócitos 3T3-L1 foram induzidos a se 
diferenciar somente com insulina $(10 \mu \mathrm{g} / \mathrm{mL})$ por 2 dias e mantidos com insulina (5 $\mu \mathrm{g} / \mathrm{mL}$ ) por 8 dias. Durante todo o período de diferenciação, as células foram tratadas com veículo (DMSO), rosiglitazona $\left(10^{-5} \mathrm{M}\right)$ ou GQ-02 $\left(10^{-5} \mathrm{M}\right)$. Ao final dos 10 dias, a diferenciação foi avaliada pela coloração com óleo vermelho $\mathrm{O}$.

Foi observado discreto aumento do acúmulo lipídico por tratamento com GQ02 em relação às células tratadas com DMSO. O acúmulo lipídico com tratamento com GQ-02 foi reduzido em relação às células com tratamento com rosiglitazona (Figura 13).

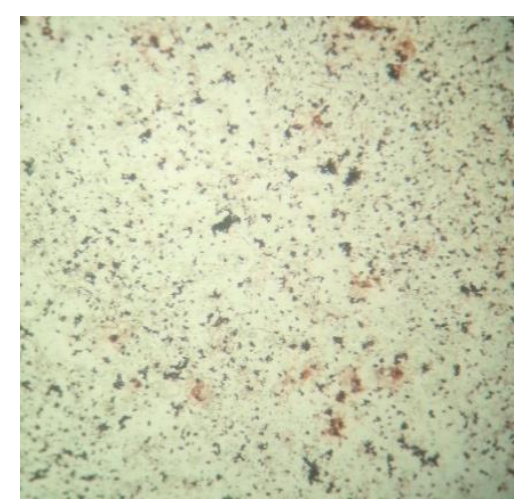

1. Não diferenciado

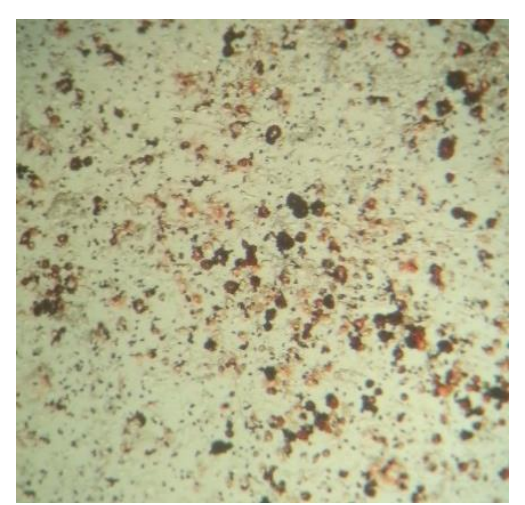

2. DMSO

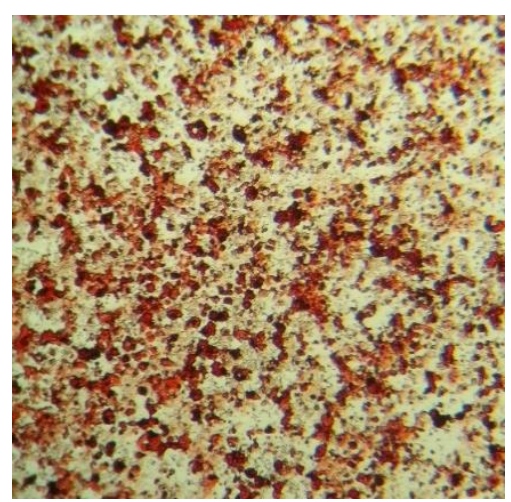

3. Rosiglitazona $10^{-5} \mathrm{M}$

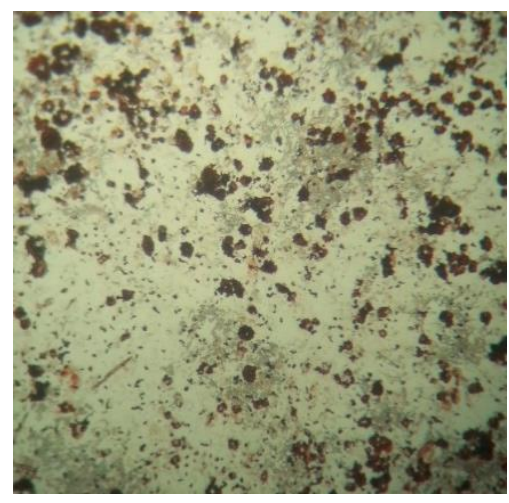

4. GQ-02 $10^{-5} \mathrm{M}$

Figura 13 Efeito do GQ-02 sobre a adipogênese em pré-adipócitos 3T3-L1 induzidos com meio incompleto. Pré-adipócitos 3T3-L1 induzidos a se diferenciar em adipócitos em meio contendo 10 $\mu \mathrm{g} / \mathrm{mL}$ de insulina por dois dias e, em seguida, mantidos em meio contendo $5 \mu \mathrm{g} / \mathrm{mL}$ de insulina. Durante o período de cultivo (10 dias), foram tratados com veículo (DMSO), rosiglitazona $\left(10^{-5} \mathrm{M}\right)$ ou GQ-02 $\left(10^{-5} \mathrm{M}\right)$. Após 10 dias, foram corados com óleo vermelho $\mathrm{O}$ e observados por microscopia. Aumento de 10x. 


\subsubsection{Caracterização do modelo animal}

Os camundongos foram divididos, aleatoriamente, na $5^{\text {a }}$ semana de vida em 4 grupos contendo 5 animais cada. Um grupo foi alimentado com DC e os demais grupos alimentados com DHL. Não foi observada diferença do peso corporal entre os grupos na $5^{\mathrm{a}}$ semana de vida, ou seja, no início do estudo (Figura 14).

A partir da 16 ${ }^{\text {a }}$ semana de vida foi observado aumento significativo do peso corporal nos grupos alimentados com DHL em comparação ao grupo alimentado com DC (Figura 14).

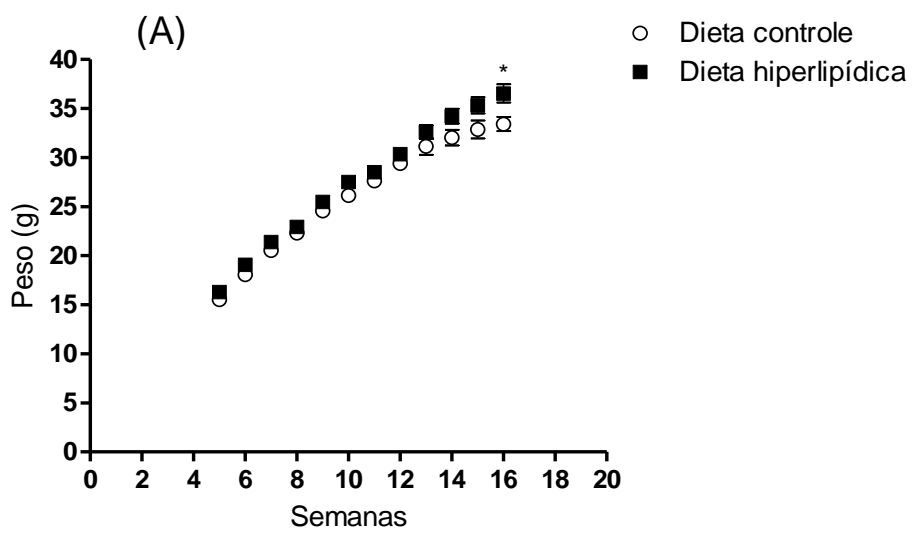

(B)

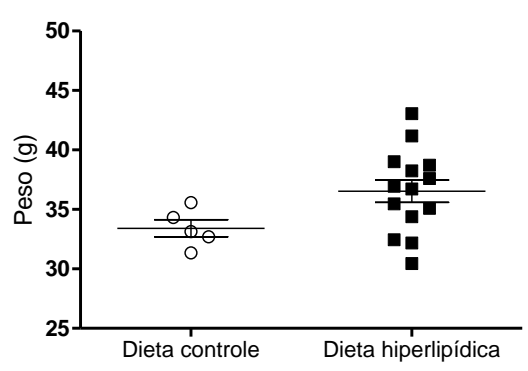

Figura 14 Ganho de peso corporal em camundongos alimentados com DC ou DHL. (A) Peso corporal desde a $5^{\underline{a}}$ até a $16^{\mathrm{a}}$ semana de vida e (B) peso corporal apresentado na $16^{\mathrm{a}}$ semana de vida em camundongos alimentados com dieta controle $(n=5)$ ou DHL $(n=14)$. Dados apresentados como média \pm EPM. * $p<0,05$ vs. grupo alimentado com DC (análise de variância de dois fatores seguida do teste de Bonferroni e teste t de Student não pareado).

Com relação à energia ingerida (Figura 15 A) e ao consumo hídrico (Figura 15 B), não foram observadas diferenças entre o grupo alimentado com DC e os grupos alimentados com DHL. 
(A)

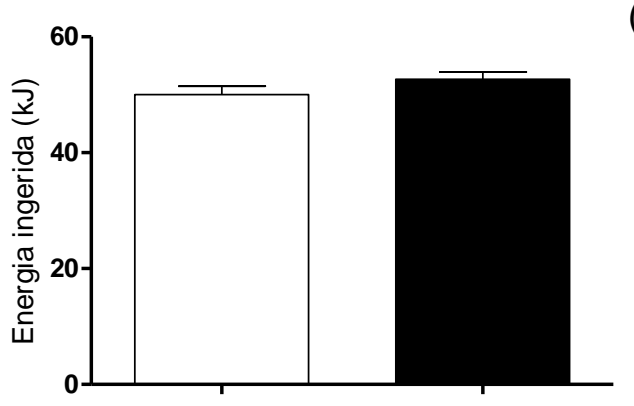

(B)

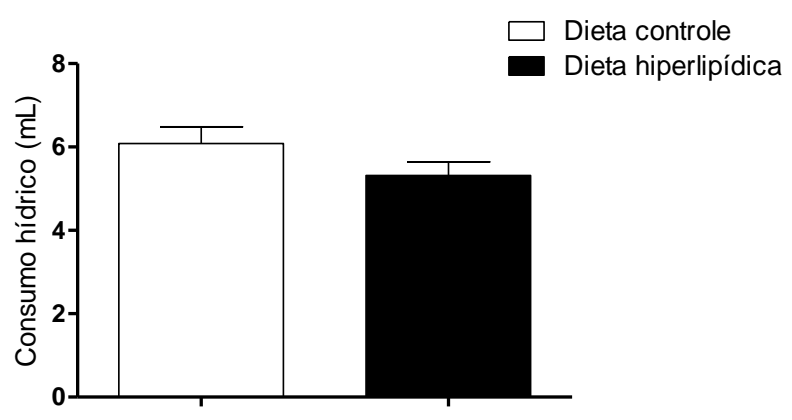

Figura 15 Consumo energético e hídrico em camundongos alimentados com DC ou DHL. (A) Energia ingerida e (B) consumo hídrico dos camundongos alimentados com dieta controle e dieta hiperlipídica da $5^{\text {a }}$ à $16^{\underline{a}}$ semana de vida. Dados apresentados como média \pm EPM (teste $t$ de Student não pareado).

$\mathrm{Na} 16^{\mathrm{a}}$ semana de vida, antes do início do tratamento, os camundongos alimentados com DHL apresentaram glicemia de jejum média de 149,0 \pm 9,27 mg/dL em comparação com glicemia de jejum média de 114,3 \pm 10,41 mg/dL observada no grupo mantido em DC (Figura 16), sem diferença estatística entre os grupos.

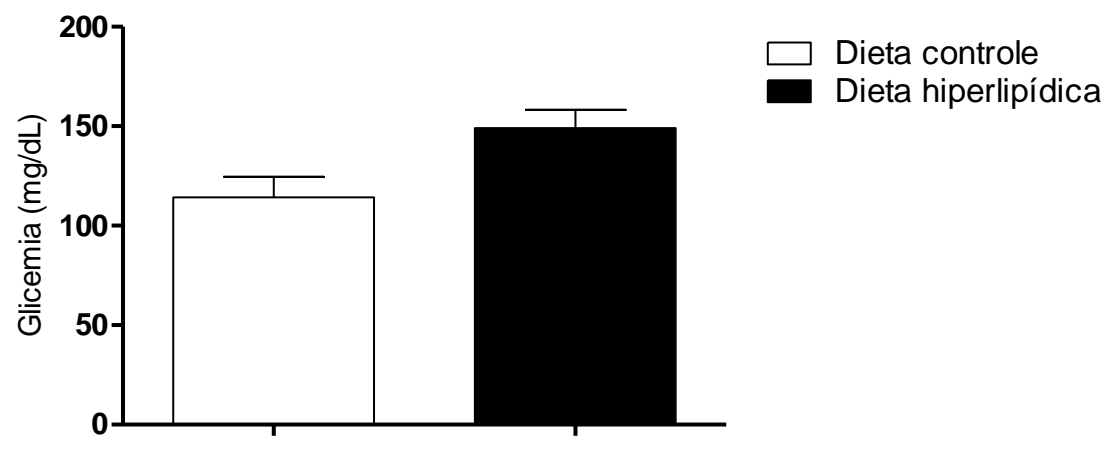

Figura 16 Glicemia de jejum em camundongos alimentados com DC ou DHL. Glicemia em jejum na $16^{\text {a }}$ semana de vida em camundongos alimentados com dieta controle $(n=5)$ ou DHL $(n=14)$ a partir da $5^{\text {a }}$ semana de vida. Dados apresentado como média \pm EPM (teste t de Student não pareado). 


\subsubsection{Efeito do GQ-02 sobre a glicemia de jejum}

Após a 16 ${ }^{\mathrm{a}}$ semana de vida, os camundongos alimentados com DHL foram subdivididos aleatoriamente em 3 grupos contendo 4 a 5 animais cada e foram tratados, diariamente, durante 21 dias, com GQ-02 (20 mg/kg/dia), rosiglitazona (4 $\mathrm{mg} / \mathrm{kg} / \mathrm{dia}$ ) ou veículo, via injeção intraperitoneal. Os camundongos alimentados com dieta DC foram tratados, por igual período de tempo, com veículo.

Foi observada redução significativa da glicemia de jejum nos grupos tratados tanto com rosiglitazona quanto com GQ-02, após 21 dias de tratamento, em relação ao grupo alimentado com DHL e tratado com veículo (Figura 17).

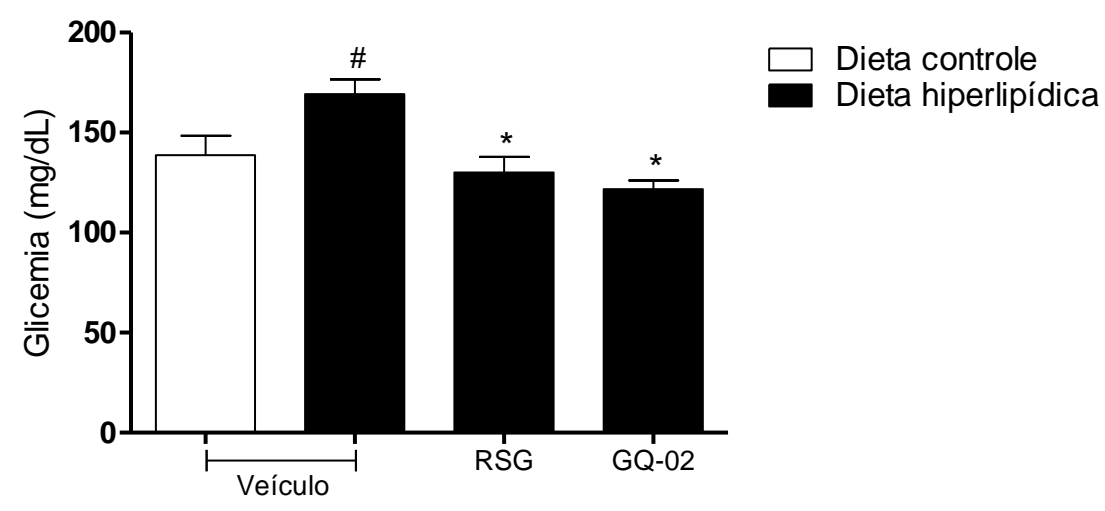

Figura 17 Efeito do GQ-02 sobre a glicemia de jejum. Glicemia em jejum após 21 dias de tratamento com veículo, rosiglitazona (4 mg/kg/dia) ou GQ-02 (20 mg/kg/dia) nos camundongos alimentados com DHL; e veículo nos camundongos alimentados com DC. Dados apresentados como média \pm EPM. \# $p<0,05$ vs dieta controle, ${ }^{*} p<0,05$ vs. DHL tratado com veículo (análise de Variância de um fator seguida de pós-teste de Newman-Keuls); $\mathrm{n}=4-5$ camundongos por grupo. RSG, rosiglitazona.

\subsubsection{Efeito do GQ-02 sobre o ganho de peso, ingestão energética e hídrica e eficiência metabólica}

Foi observada perda de peso induzido por DHL nos animais tratados com GQ-02 (20 mg/kg/dia) em comparação com os demais grupos, como demonstrado na figura 18. 
(A)

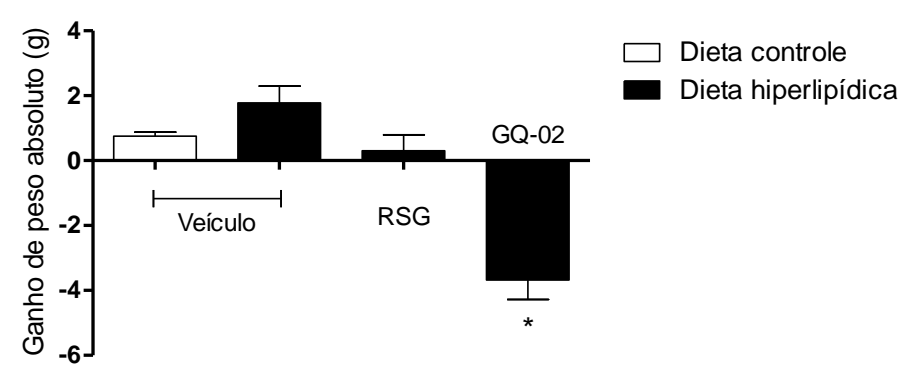

(B)

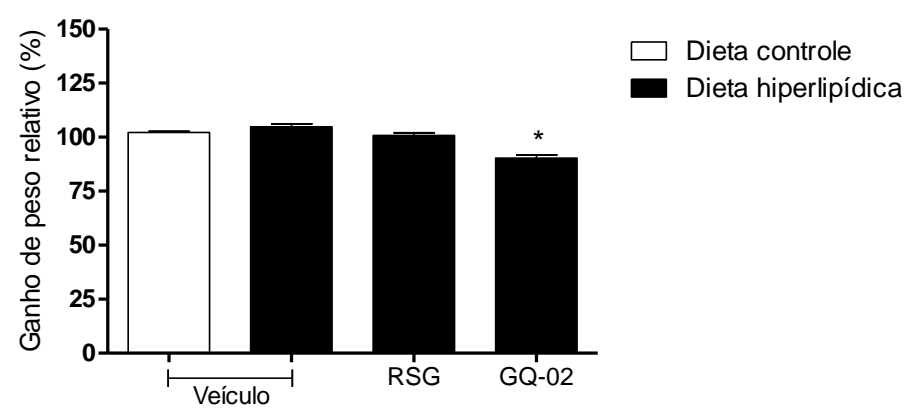

Figura 18 Efeito do GQ-02 sobre o ganho ponderal induzido por DHL. (A) Ganho de peso absoluto, em g, e (B) ganho de peso relativo, em \%, após 21 dias de tratamento com veículo, rosiglitazona (4 $\mathrm{mg} / \mathrm{kg} / \mathrm{dia}$ ) ou GQ-02 (20 mg/kg/dia) nos camundongos alimentados com dieta DHL ou alimentados com DC e tratados com veículo. Dados apresentados como média \pm EPM. * $p<0.05$ vs. todos os grupos (análise de variância de um fator seguida de pós-teste de Newman-Keuls); $n=4-5$ camundongos por grupo. RSG, rosiglitazona.

Foi observada diminuição da energia ingerida dos animais tratados com GQ02 e alimentados com DHL em relação aos demais grupos (Figura 19 A) e, com relação ao consumo hídrico, não houve diferença entre os grupos em estudo (Figura $19 \mathrm{~B})$.

(A)

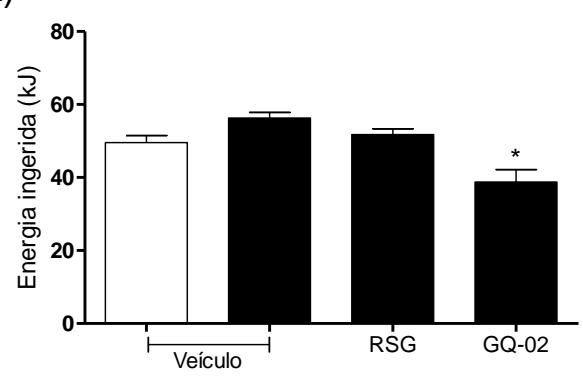

(B)

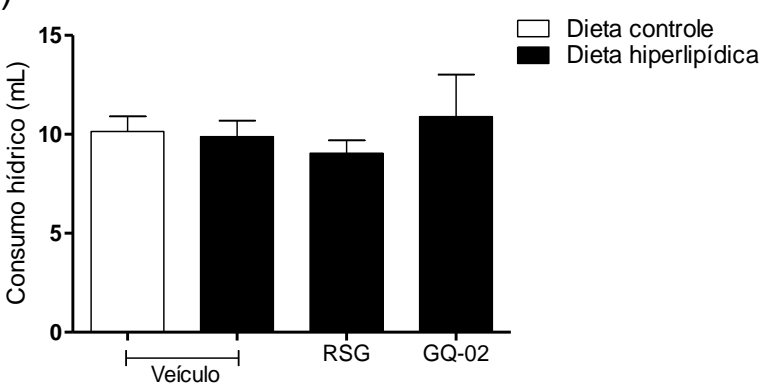

Figura 19 Efeito do GQ-02 sobre o consumo energético e hídrico. (A) Energia ingerida e (B) consumo hídrico dos camundongos após 21 dias de tratamento com veículo, rosiglitazona (4 mg/kg/dia) ou GQ02 (20 mg/kg/dia) nos camundongos alimentados com DHL ou tratamento com veículo e alimentados com DC. Dados apresentados como média \pm EPM. \# $p<0,05$ vs grupo alimentado com $D C,{ }^{*} p<0,05$ vs. todos os grupos (análise de variância de um fator seguida de pós-teste de Newman-Keuls); $\mathrm{n}=4$ 5 camundongos por grupo. RSG, rosiglitazona. 
Foi verificada redução significativa da eficiência metabólica dos animais que receberam GQ-02 (20 mg/kg/dia) quando comparados aos animais dos demais grupos, como apresentado na Figura 20.

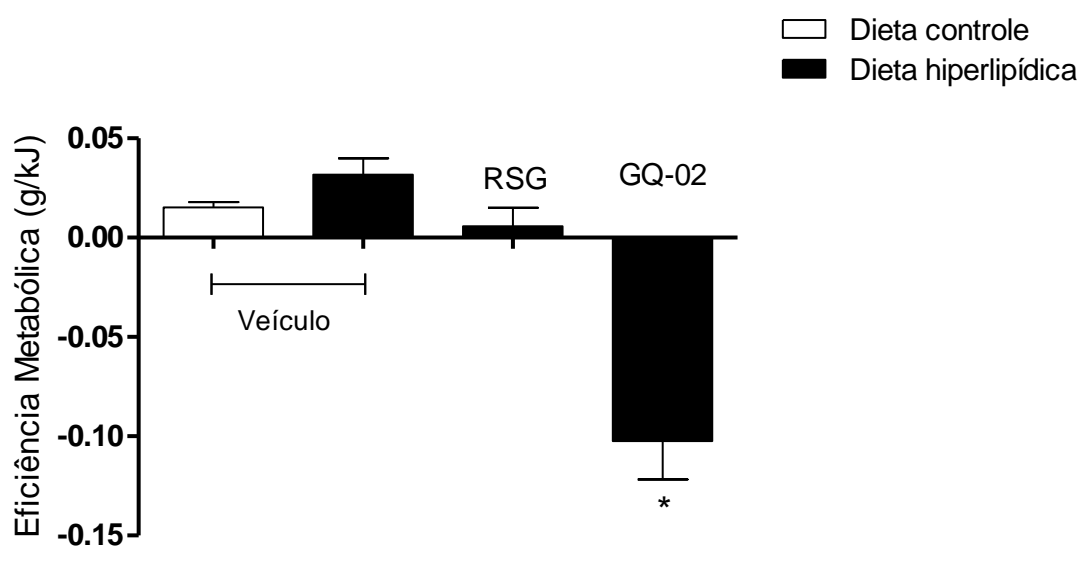

Figura 20 Efeito do GQ-02 sobre a eficiência metabólica. Eficiência metabólica (calculada como ganho de peso, em g, dividido pela energia ingerida, em kJ), após 21 dias de tratamento com veículo, rosiglitazona (4 mg/kg/dia) ou GQ-02 (20 mg/kg/dia) nos camundongos alimentados com DHL ou alimentados com DC e tratados com veículo. Dados apresentados como média \pm EPM. * $p<0,05$ vs. todos os grupos (análise de variância de um fator seguida de pós-teste de Newman-Keuls). $n=4-5$ camundongos por grupo. RSG, rosiglitazona.

\subsubsection{Efeito do GQ-02 sobre a adiposidade}

Foi observado aumento significativo da massa do tecido adiposo branco visceral epididimal no grupo tratado com veículo e alimentado com DHL em relação ao grupo alimentado com DC (Figura 21). Os animais alimentados com DHL e tratados com GQ-02 apresentaram redução da massa do depósito de TAB visceral epididimal quando comparados aos animais alimentados com $\mathrm{DHL}$ e tratados com veículo (Figura 21). 


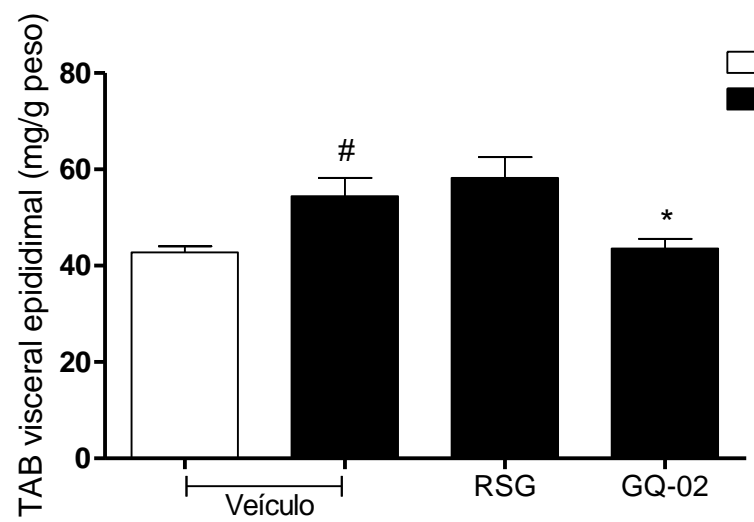

Figura 21 Efeito do GQ-02 sobre a massa do tecido adiposo branco visceral epididimal após 21 dias de tratamento com veículo, rosiglitazona (4 mg/kg/dia) ou GQ-02 (20 mg/kg/dia) nos camundongos alimentados com DHL; e veículo nos camundongos alimentados com DC. Dados apresentados como média \pm EPM. $\# p<0,05$ vs dieta controle, ${ }^{*} p<0,05$ vs. DHL tratado com veículo (análise de Variância de um fator seguida de pós-teste de Newman-Keuls); $\mathrm{n}=4-5$ camundongos por grupo. RSG, rosiglitazona.

A massa do tecido adiposo branco subcutâneo inguinal não apresentou diferença significativa entre os grupos (Figura 22).

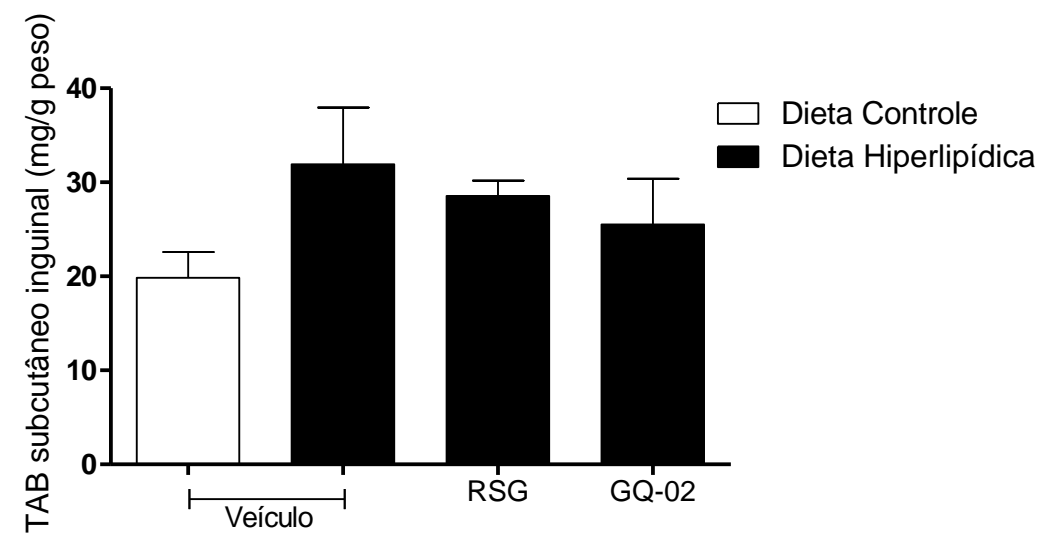

Figura 22 Efeito do GQ-02 sobre a massa do tecido adiposo branco subcutâneo inguinal após 21 dias de tratamento com veículo, rosiglitazona (4 mg/kg/dia) ou GQ-02 (20 mg/kg/dia) nos camundongos alimentados com DHL; e veículo nos camundongos alimentados com DC. Dados apresentados como média \pm EPM. $\# p<0,05$ vs dieta controle, ${ }^{*} p<0,05$ vs. DHL tratado com veículo (análise de Variância de um fator seguida de pós-teste de Newman-Keuls); $\mathrm{n}=4-5$ camundongos por grupo. RSG, rosiglitazona.

O depósito de tecido adiposo marrom interescapular apresentou redução significativa nos animais tratados com veículo e alimentados com DHL em comparação àqueles tratados com veículo e alimentados com DC (Figura 23). O tratamento com rosiglitazona induziu aumento significativo da massa do TAM em 
relação ao tratamento com veículo nos animais alimentados com DHL (Figura 23). GQ-02 não induziu alteração da massa deste depósito de TAM em relação ao veículo, nos animais alimentado com DHL.

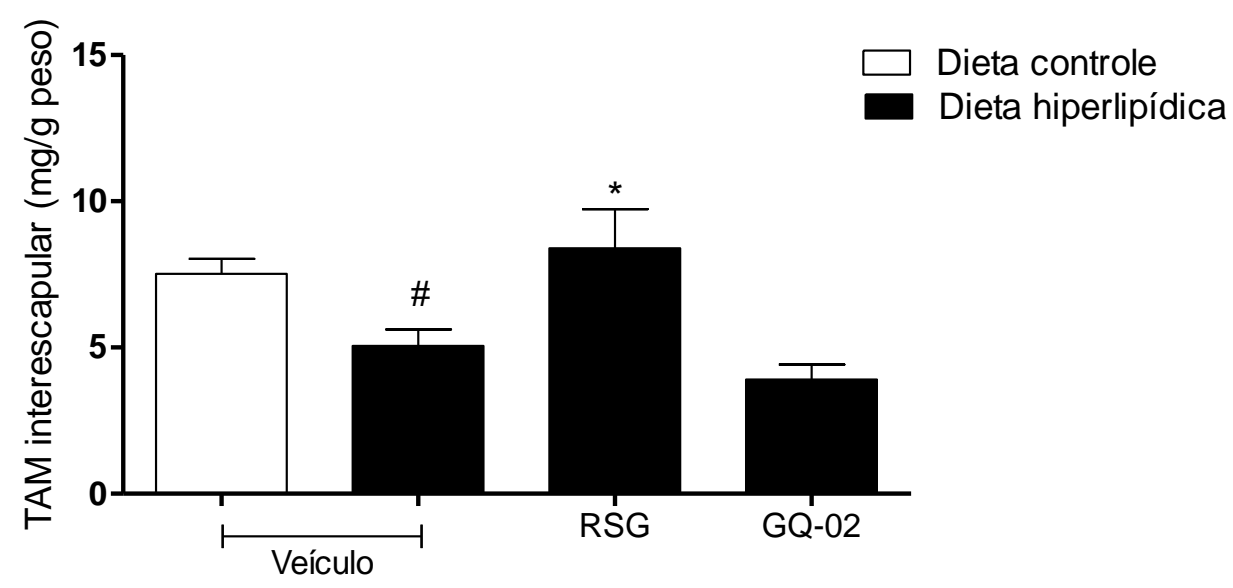

Figura 23 Efeito do GQ-02 sobre a massa do tecido adiposo marrom interescapular após 21 dias de tratamento com veículo, rosiglitazona (4 mg/kg/dia) ou GQ-02 (20 mg/kg/dia) nos camundongos alimentados com DHL; e veículo nos camundongos alimentados com DC. Dados apresentados como média \pm EPM. $\# p<0,05$ vs dieta controle, ${ }^{*} p<0,05$ vs. DHL tratado com veículo (análise de Variância de um fator seguida de pós-teste de Newman-Keuls); $\mathrm{n}=4-5$ camundongos por grupo. RSG, rosiglitazona.

\subsubsection{Efeito do GQ-02 sobre o peso do coração, rins e testículos}

Não foram observadas diferenças nas massas cardíaca (Figura $24 \mathrm{~A}$ ), renal (Figura 24 B) ou testicular (Figura $24 \mathrm{C}$ ) entre os diferentes tratamentos, nos animais alimentados com DHL, ou entre estes e os animais tratados com veículo e alimentados com DC (Figura 24). 
(A)

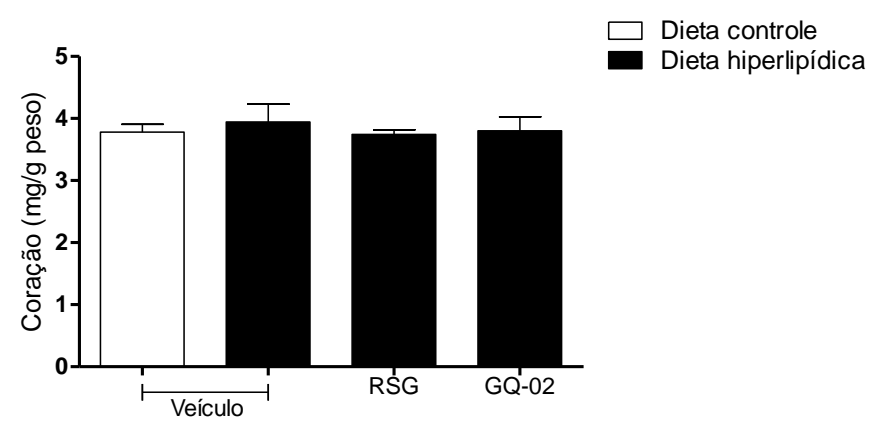

(B)

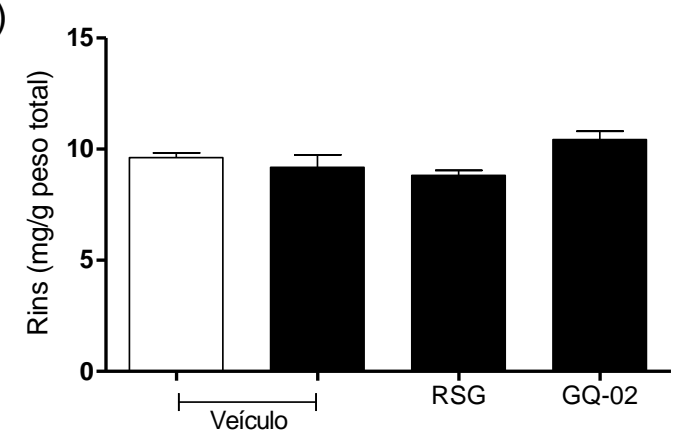

(C)

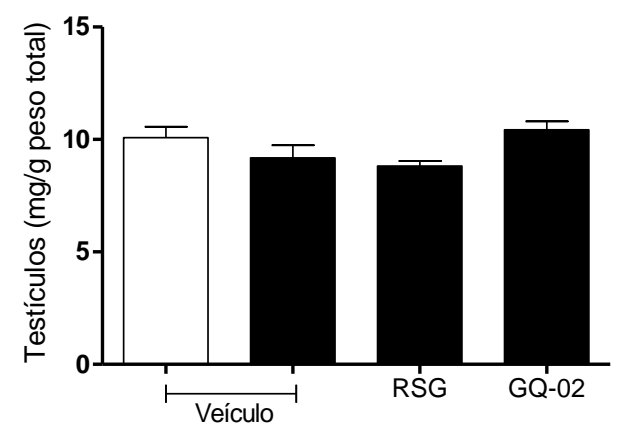

Figura 24 Efeito do GQ-02 sobre a (A) massa do coração, (B) massa dos rins e (C) massa dos testículos após 21 dias de tratamento com veículo, rosiglitazona (4 mg/kg/dia) ou GQ-02 (20 $\mathrm{mg} / \mathrm{kg} / \mathrm{dia}$ ) nos camundongos alimentados com DHL; e veículo nos camundongos alimentados com DC. Dados apresentados como média \pm EPM (análise de Variância de um fator seguida de pós-teste de Newman-Keuls); $\mathrm{n}=4-5$ camundongos por grupo. RSG, rosiglitazona.

\subsubsection{Efeito do GQ-02 sobre o consumo de oxigênio}

A taxa de consumo de oxigênio foi mensurada em amostras de tecido dos depósitos de TAB visceral (epididimal), TAB subcutâneo (inguinal) e TAM (interescapular).

No TAB epididimal (depósito visceral), não foi observada diferença entre os grupos tratados com veículo e alimentados com DC ou DHL, nem entre os tratamentos nos camundongos alimentados com DHL (Figura 25). Foi observada, no entanto, tendência de aumento da taxa de consumo de oxigênio nos animais tratados com GQ-02 e alimentados com DHL, quando comparados aos demais grupos. (Figura 25). Tendência contrária (de redução do consumo de oxigênio) foi observada nos animais tratados com RSG e alimentados com DHL, em comparação aos demais grupos (Figura 25). 
(A)

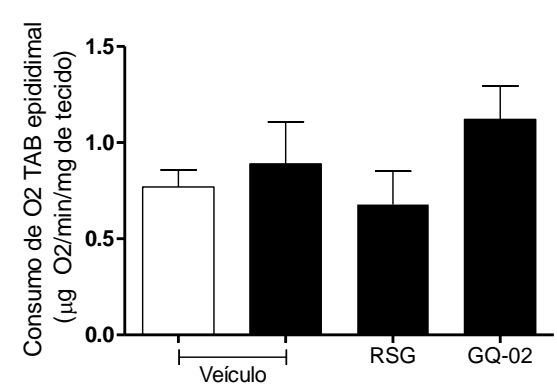

(B)

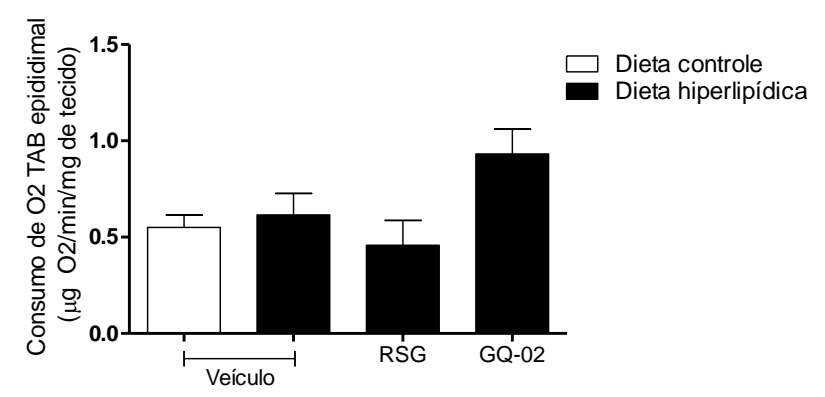

Figura 25 Efeito do GQ-02 sobre o consumo de oxigênio do tecido adiposo branco epididimal visceral por (A) 1 minuto e (B) 5 minutos. Consumo de oxigênio mensurado a partir de fragmentos de aproximadamente 30 a $80 \mathrm{mg}$ de tecido adiposo visceral em camundongos após 21 dias de tratamento com veículo, rosiglitazona (4 mg/kg/dia) ou GQ-02 (20 mg/kg/dia) nos camundongos alimentados com dieta DHL ou tratamento com veículo e alimentados com DC. A taxa de respiração celular foi mensurada em câmara de respiração contendo DPBS 1x (Dulbecco's phosphate-buffer saline), $2 \%$ de albumina de soro bovino, $25 \mathrm{mM}$ de glicose e $1 \mathrm{mM}$ de piruvato, mantido a $37^{\circ} \mathrm{C}$, por 1 e 5 minutos. Dados apresentados como média \pm EPM. * $p<0,05$ vs. DHL tratado com veículo (análise de Variância de um fator seguida de pós-teste de Newman-Keuls); $n=4-5$ camundongos por grupo. RSG, rosiglitazona.

Não foram observadas diferenças significativas do consumo de oxigênio entre os grupos no TAB inguinal (depósito subcutâneo) (Figura 26), embora tenha sido verificada tendência de redução da taxa de consumo de oxigênio neste depósito em resposta ao tratamento com RSG, em comparação com os demais tratamentos (Figura 26), mais evidente na mensuração após 1 minuto.

(A)

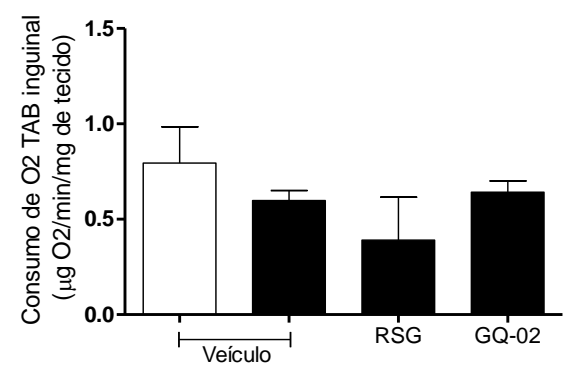

(B)

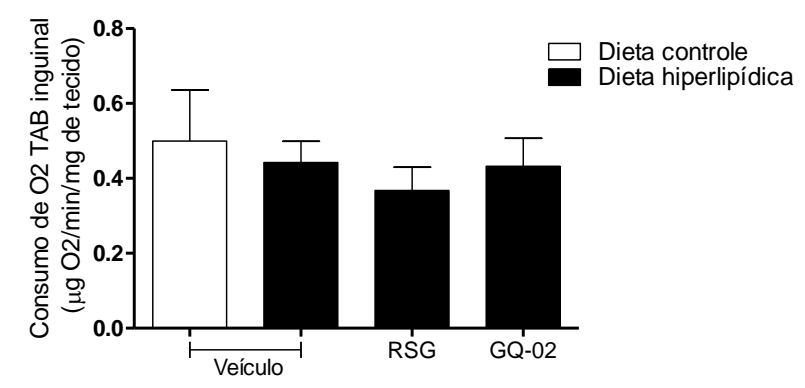

Figura 26 Efeito do GQ-02 sobre o consumo de oxigênio do tecido adiposo branco inguinal subcutâneo por (A) 1 minutos e (B) 5 minutos. Consumo de oxigênio mensurado a partir de fragmentos de aproximadamente $30 \mathrm{a} 80 \mathrm{mg}$ de tecido adiposo subcutâneo em camundongos após 21 dias de tratamento com veículo, rosiglitazona (4 mg/kg/dia) ou GQ-02 (20mg/kg/dia) nos camundongos alimentados com dieta $\mathrm{DHL}$ ou tratamento com veículo e alimentados com DC. A taxa de respiração celular foi mensurada em câmara de respiração contendo DPBS 1x (Dulbecco's phosphate-buffer saline), $2 \%$ de albumina de soro bovino, $25 \mathrm{mM}$ de glicose e $1 \mathrm{mM}$ de piruvato, mantido a $37^{\circ} \mathrm{C}$, por 1 e 5 minutos. Dados apresentados como média \pm EPM (análise de Variância de um fator seguida de pós-teste de Newman-Keuls); $\mathrm{n}=4-5$ camundongos por grupo. RSG, rosiglitazona. 
Não foram observadas diferenças significativas no consumo de oxigênio mensurado no TAM interescapular entre os grupos de tratamento alimentados com $\mathrm{DHL}$, ou entre tratamento com veículo e os grupos alimentados com DC e DHL (Figura 27).

(A)

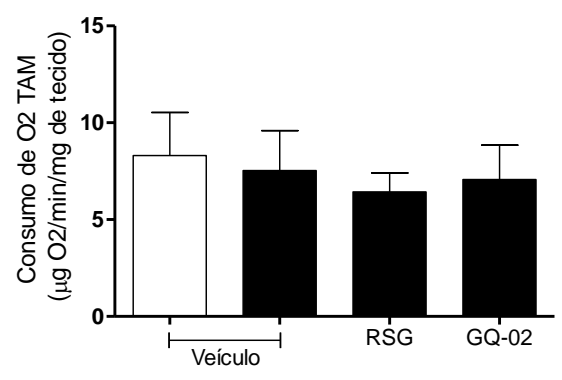

(B)

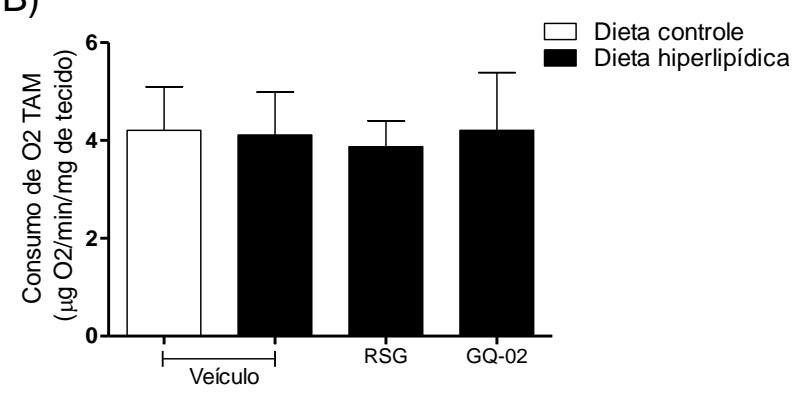

Figura 27 Efeito do GQ-02 sobre o consumo de oxigênio do tecido adiposo marrom interescapular por (A) 1 minuto e (B) 5 miutos. Consumo de oxigênio mensurado a partir de fragmentos de aproximadamente 10 a $30 \mathrm{mg}$ de tecido adiposo marrom em camundongos após 21 dias de tratamento com veículo, rosiglitazona (4 mg/kg/dia) ou GQ-02 (20 mg/kg/dia) nos camundongos alimentados com dieta DHL ou tratamento com veículo e alimentados com DC. A taxa de respiração celular foi mensurada em câmara de respiração contendo DPBS 1x (Dulbecco's phosphate-buffer saline), $2 \%$ de albumina de soro bovino, $25 \mathrm{mM}$ de glicose e $1 \mathrm{mM}$ de piruvato, mantido a $37^{\circ} \mathrm{C}$, por 1 e 5 minutos. Dados apresentados como média \pm EPM (análise de Variância de um fator seguida de pós-teste de Newman-Keuls); $\mathrm{n}=4-5$ camundongos por grupo. RSG, rosiglitazona.

\subsubsection{Efeito do GQ-02 sobre características histológicas do tecido adiposo e fígado}

Amostras dos depósitos de tecido adiposo branco visceral epididimal, branco subcutâneo inguinal e marrom interescapular, além de amostras do fígado, foram fixadas em paraformaldeído $4 \%$ e incluídas em parafina. A análise histológica foi realizada após coloração com hematoxilina-eosina e imagens capturadas por microscópio de luz com aumento de 10 vezes, representativas de um animal por grupo.

No TAB epididimal (depósito visceral) e inguinal (depósito subcutâneo) foi observado aumento do tamanho dos adipócitos nos camundongos alimentados com DHL e tratados com veículo quando comparados aos animais alimentados com dieta controle (Figuras 28 e 29). 
Os camundongos alimentados com DHL e tratados com RSG apresentaram características histológicas nos depósitos de TAB visceral e subcutâneo similares ao grupo alimentado com DHL e tratado com veículo, com o aumento do tamanho dos adipócitos em relação aos camundongos mantidos em DC (Figuras 28 e 29).

No depósito visceral (Figura 28), os animais alimentados com DHL e tratados com GQ-02 apresentaram redução do tamanho do adipócito em relação aos camundongos alimentados com DHL e tratados com veículo, indicado por tendência de redução do diâmetro dos adipócitos e tamanho das gotículas lipídicas. Em relação ao depósito subcutâneo (Figura 29), não foi observada modificação das características histológicas nos camundongos tratados com GQ-02 em relação aos animais tratados com veículo e alimentados com DHL.

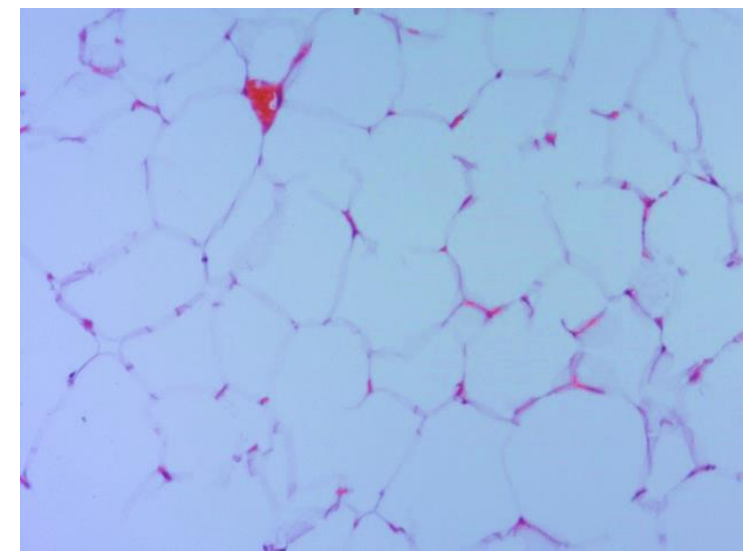

1. DC - veículo

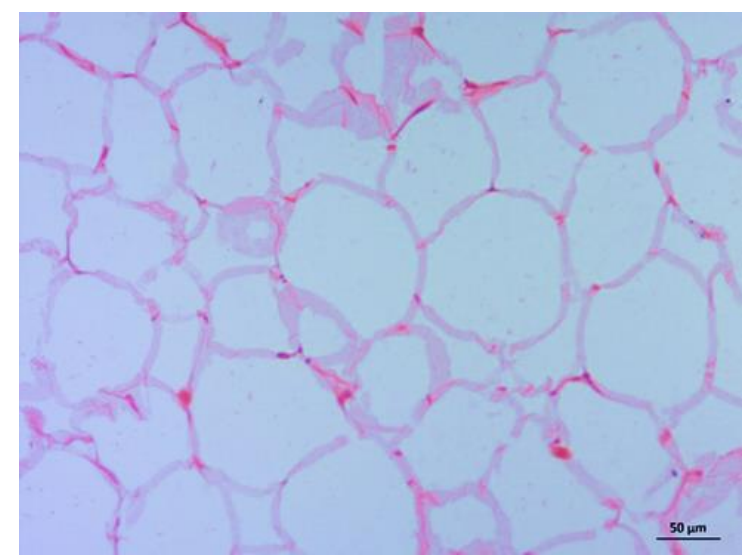

3. DHL - RSG

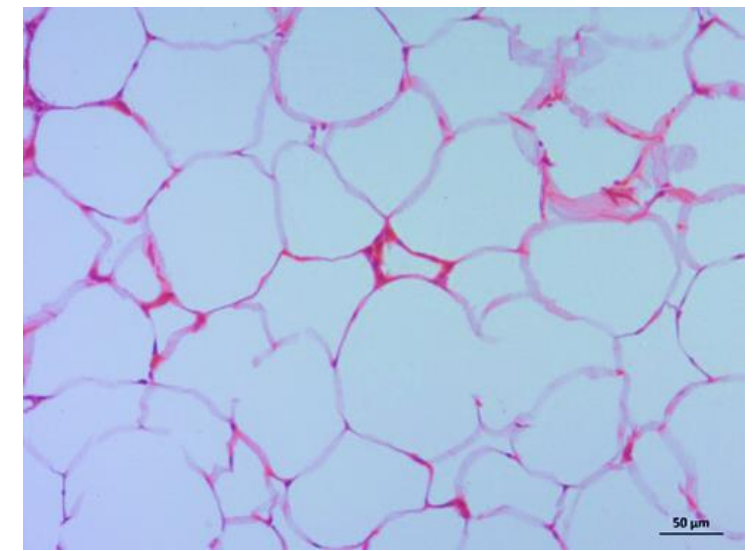

2. DHL - veículo

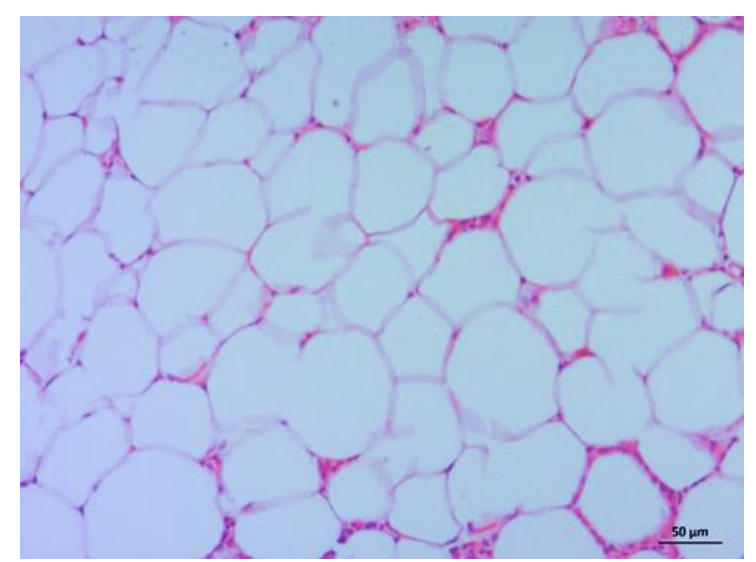

4. $\mathrm{DHL}-\mathrm{GQ}-02$

Figura 28 Efeito do GQ-02 sobre características morfológicas do tecido adiposo branco visceral epididimal após 21 dias de tratamento com veículo, rosiglitazona (4 mg/kg/dia) ou GQ-02 (20 $\mathrm{mg} / \mathrm{kg} / \mathrm{dia}$ ) nos camundongos alimentados com DHL; e veículo nos camundongos alimentados com DC. Amostras de tecido adiposo branco epididimal coradas com hematoxilina e eosina. Imagens representativas de um camundongo por grupo, aumento de 10 vezes e escala de $50 \mu \mathrm{m}$. $\mathrm{n}=4-5$ camundongos por grupo. RSG, rosiglitazona; DC, dieta controle; DHL, dieta hiperlipídica. 


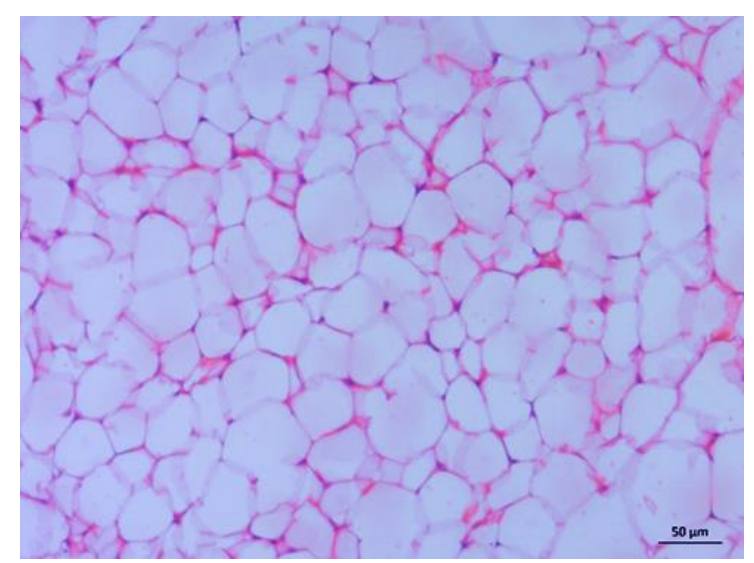

1. DC - veículo

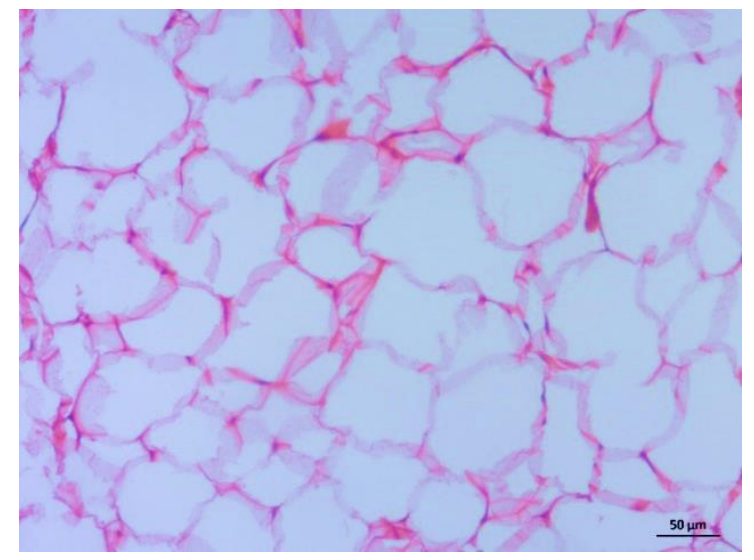

3. $\mathrm{DHL}-\mathrm{RSG}$

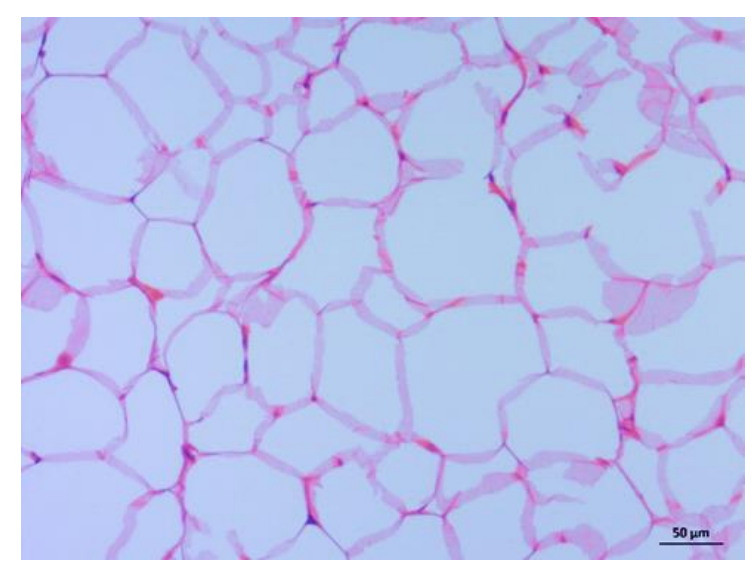

2. DHL - veículo

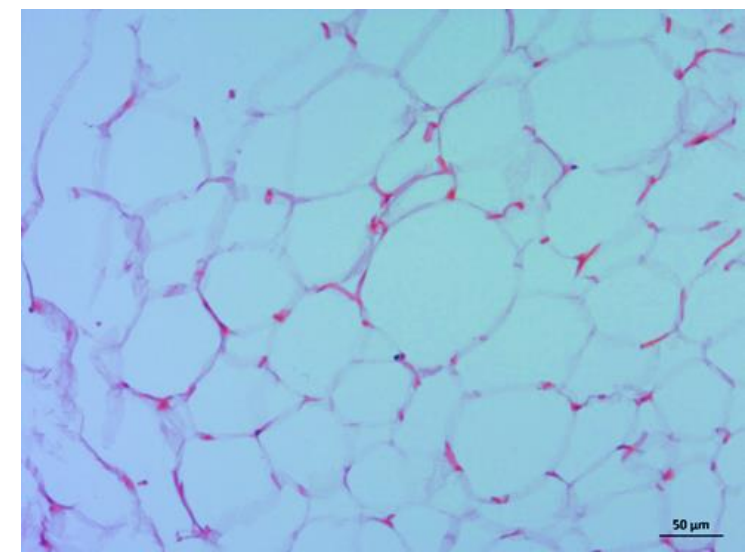

4. $\mathrm{DHL}-\mathrm{GQ}-02$

Figura 29 Efeito do GQ-02 sobre características morfológicas do tecido adiposo branco subcutâneo inguinal após 21 dias de tratamento com veículo, rosiglitazona (4 mg/kg/dia) ou GQ-02 (20 mg/kg/dia) nos camundongos alimentados com DHL; e veículo nos camundongos alimentados com DC. Amostras de tecido adiposo branco epididimal coradas com hematoxilina e eosina. Imagens representativas de um camundongo por grupo, aumento de 10 vezes e escala de $50 \mu \mathrm{m}$. $n=4-5$ camundongos por grupo. RSG, rosiglitazona; DC, dieta controle; DHL, dieta hiperlipídica.

A análise das características histológicas do TAM interescapular sugeriu maior acúmulo lipídico nos animais tratados com veículo e alimentados com DHL em relação à DC, indicado pelo aumento de tamanho das gotículas lipídicas intracelulares neste tecido (Figura 30). Os animais alimentados com DHL e tratados com RSG também apresentaram aumento do tamanho das gotículas e acúmulo lipídico no depósito marrom, porém de forma menos acentuada. O tratamento com GQ-02 nos camundongos alimentados com DHL reduziu o acúmulo e o tamanho das gotículas lipídicas em relação aos camundongos tratados com veículo e alimentados com DHL, neste depósito de tecido adiposo. 


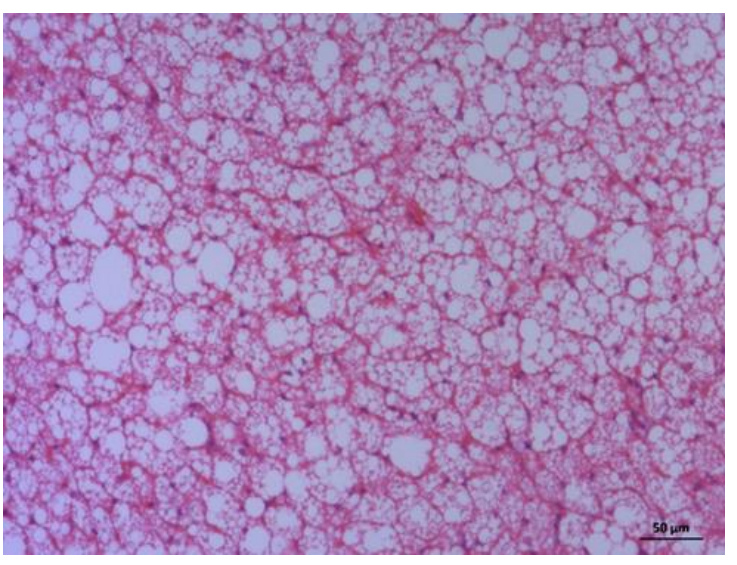

1. DC - veículo

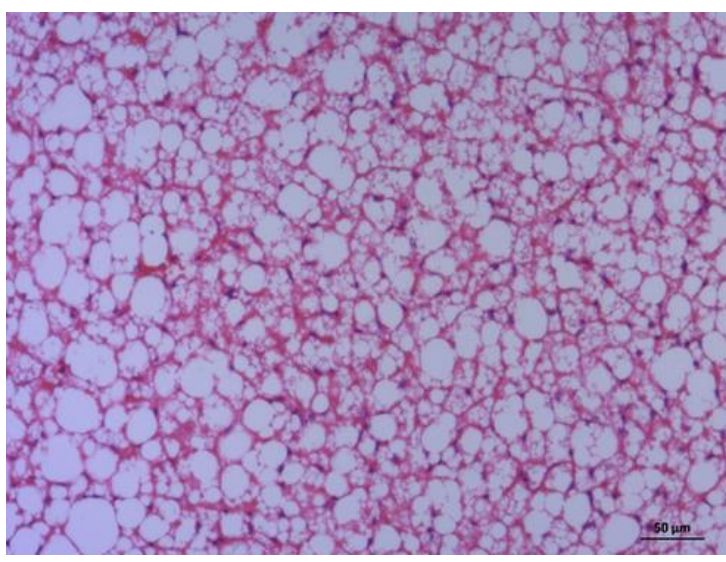

3. DHL - RSG

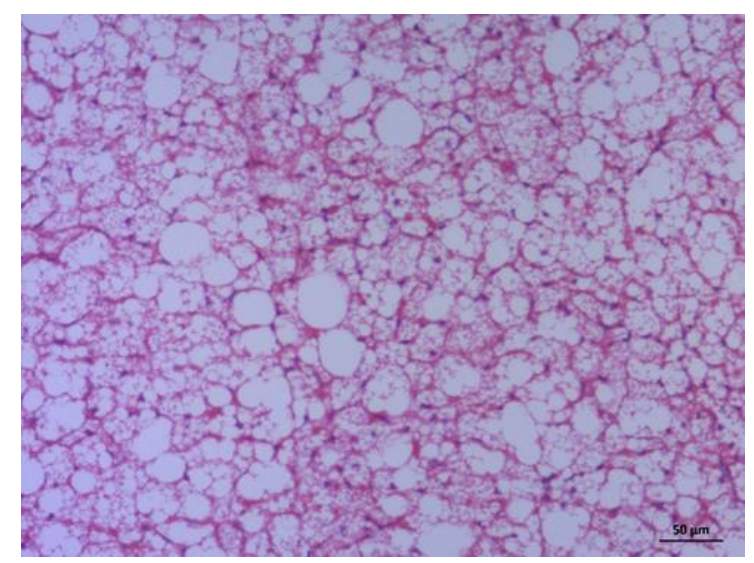

2. DHL - veículo

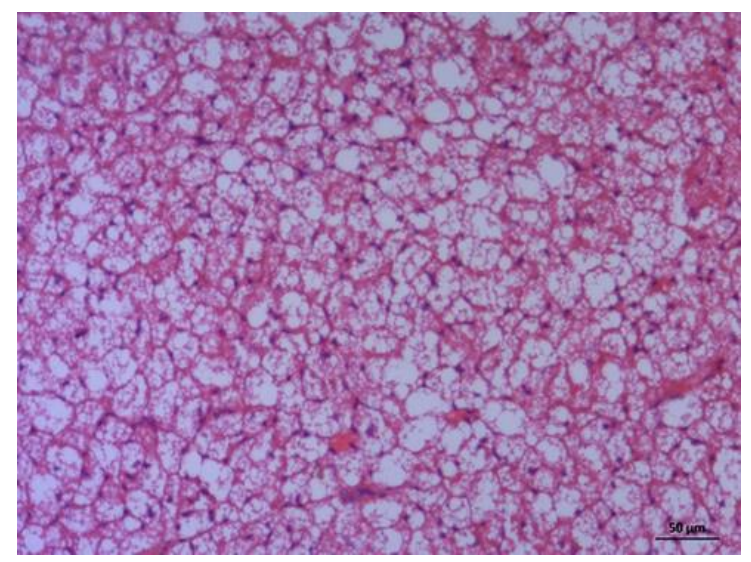

4. $\mathrm{DHL}-\mathrm{GQ}-02$

Figura 30 Efeito do GQ-02 sobre características morfológicas do tecido adiposo marrom interescapular após 21 dias de tratamento com veículo, rosiglitazona (4 mg/kg/dia) ou GQ-02 (20 $\mathrm{mg} / \mathrm{kg} / \mathrm{dia}$ ) nos camundongos alimentados com DHL; e veículo nos camundongos alimentados com DC. Amostras de tecido adiposo marrom coradas com hematoxilina e eosina. Imagens representativas de um camundongo por grupo, aumento de 10 vezes e escala de $50 \mu \mathrm{m}$. $\mathrm{n}=4-5$ camundongos por grupo. RSG, rosiglitazona; DC, dieta controle; DHL, dieta hiperlipídica.

No fígado, foi observado aumento do acúmulo lipídico, caracterizado pela presença de gotículas lipídicas nos hepatócitos, nos camundongos alimentados com DHL e tratados com veículo ou RSG, quando comparados aos animais alimentados com DC. Os camundongos alimentados com DHL e tratados com GQ-02 apresentaram redução das gotículas lipídicas nos hepatócitos e do acúmulo lipídico no fígado em relação ao grupo mantido com DHL e veículo (Figura 31). 


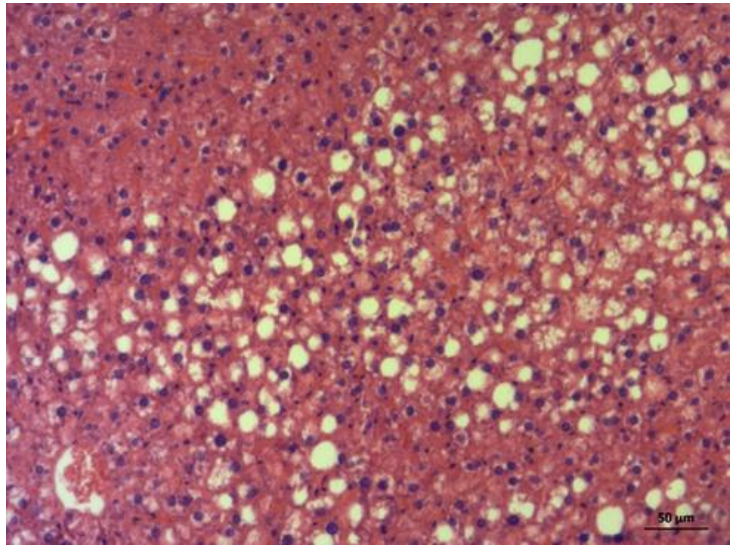

1. DC - veículo

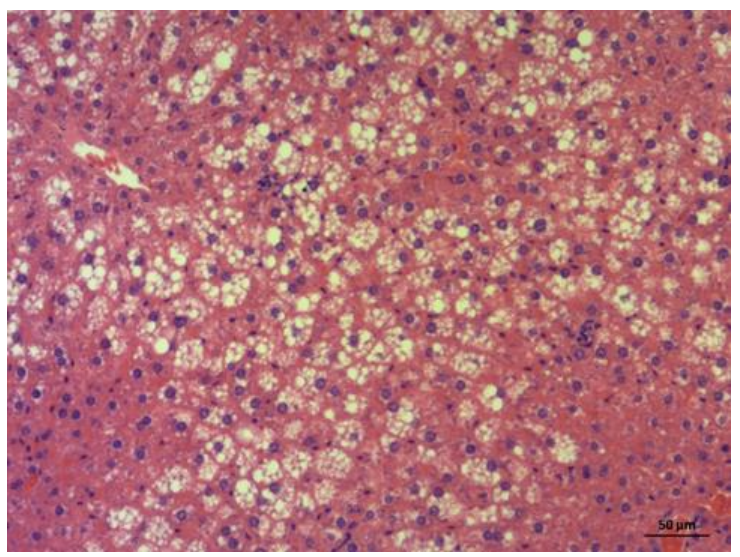

3. $\mathrm{DHL}-\mathrm{RSG}$

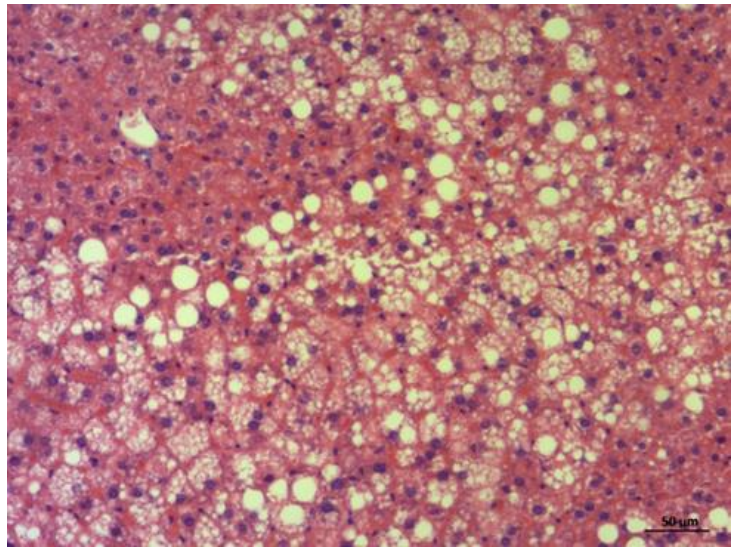

2. DHL - veículo

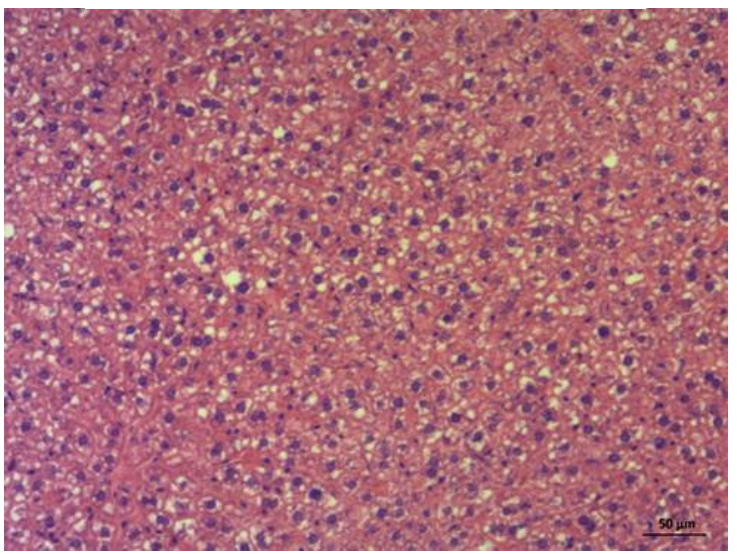

4. $\mathrm{DHL}-\mathrm{GQ}-02$

Figura 31 Efeito do GQ-02 sobre características morfológicas do fígado após 21 dias de tratamento com veículo, rosiglitazona (4 mg/kg/dia) ou GQ-02 (20 mg/kg/dia) nos camundongos alimentados com DHL; e veículo nos camundongos alimentados com DC. Amostras de fígado coradas com hematoxilina e eosina. Imagens representativas de um camundongo por grupo, aumento de 10 vezes e escala de $50 \mu \mathrm{m} . \mathrm{n}=4-5$ camundongos por grupo. RSG, rosiglitazona; DC, dieta controle; DHL, dieta hiperlipídica.

\subsubsection{Efeito do GQ-02 sobre a dosagem de triglicerídeos}

A dosagem de $T G$ foi realizada por extração dos $T G$ a partir de fragmentos de tecido hepático. Foi observada tendência de aumento no conteúdo de TG hepáticos nos animais alimentados com DHL em relação ao grupo alimentado com DC (Figura 32).

Entre os tratamentos, foi observado redução significativa da dosagem de TG no fígado dos animais tratados com GQ-02 em relação ao conteúdo de TG do grupo alimentado com DHL e tratado com veículo (Figura 32). 


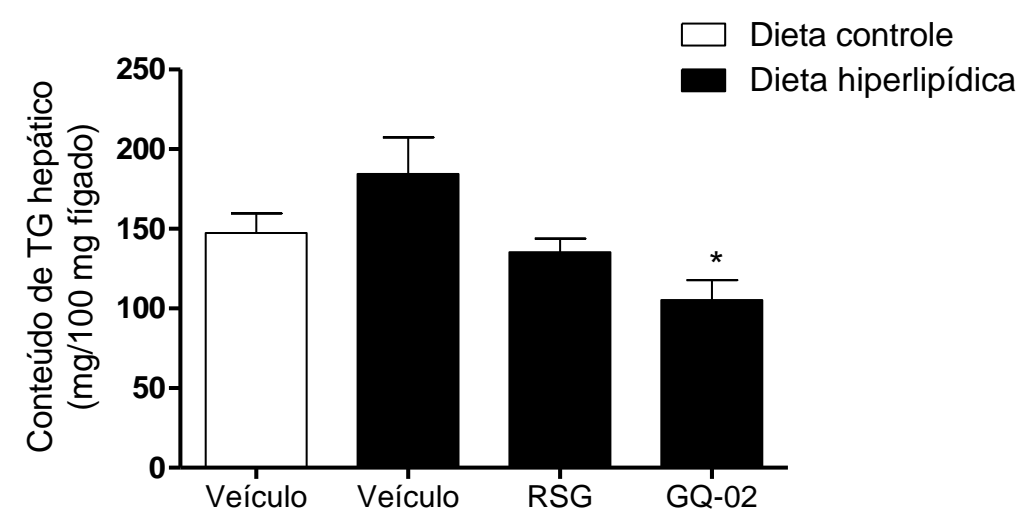

Figura 32 Efeito do GQ-02 sobre a dosagem de TG hepático. Conteúdo de triglicerídeos do fígado após 21 dias de tratamento com veículo, rosiglitazona (4 mg/kg/dia) ou GQ-02 (20 mg/kg/dia) nos camundongos alimentados com DHL; e veículo nos camundongos alimentados com DC. Dados apresentados como média \pm EPM. * $p<0,05$ vs. DHL tratado com veículo (análise de Variância de um fator seguida de pós-teste de Newman-Keuls); $\mathrm{n}=4-5$ camundongos por grupo. RSG, rosiglitazona.

\subsection{EXPRESSÃO GÊNICA}

\subsubsection{Efeitos do GQ-02 sobre a expressão de gene relacionado à termogênese no tecido adiposo}

A expressão relativa do RNAm do gene Ucp1 no tecido adiposo branco visceral epididimal, nos animais alimentados com DHL, observou-se aumento significativo com o grupo tratado com GQ-02, em relação aos animais tratados com veículo (Figura $33 \mathrm{~A}$ ).

No tecido adiposo branco subcutâneo, não foi observado diferença da expressão relativa do RNAm da Ucp1 entre os grupos (Figura $33 \mathrm{~B}$ ), com tendência de aumento da expressão relativa do RNAm da Ucp1 nos tratamentos com RSG e GQ-02 em relação ao grupo tratado com veículo.

No tecido adiposo marrom, foi observado tendência de aumento da expressão relativa de Ucp1 com tratamento com o GQ-02 em relação ao grupo alimentado com DHL e tratado com veículo (Figura $33 \mathrm{C}$ ). Não foi observado alteração na expressão 
relativa do RNAm da Ucp1 com tratamento com $\mathrm{RSG}$, em relação ao grupo tratado com veículo.

(A)

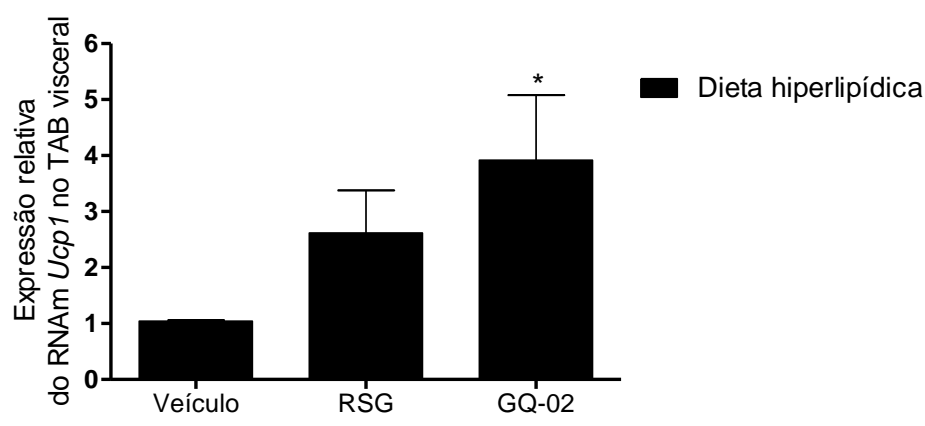

(B)

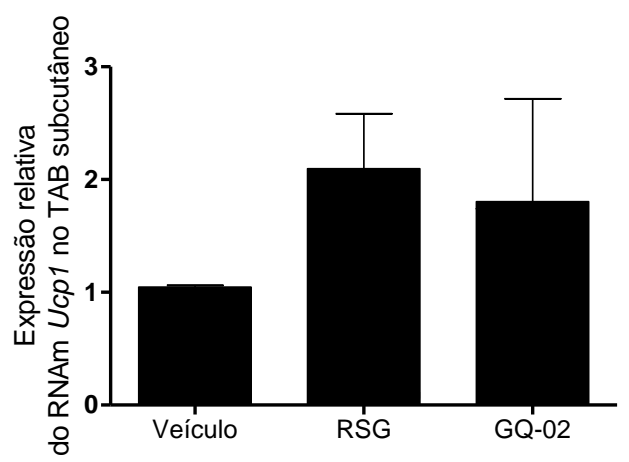

(C)

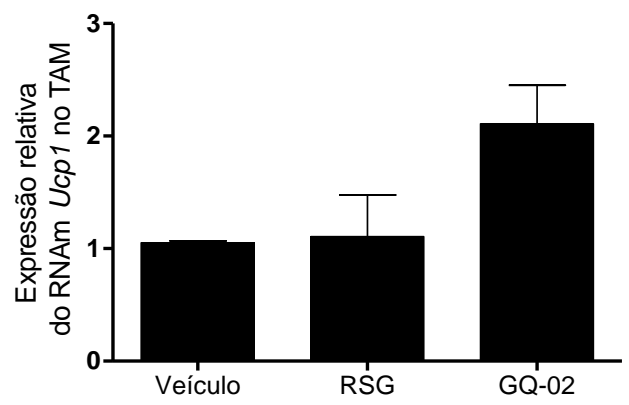

Figura 33. Efeito do GQ-02 sobre a expressão de RNAm do gene relacionado à termogênese Ucp1. Expressão do RNAm de gene relacionados à termogênese no (A) Tecido adiposo branco visceral epididimal, (B) tecido adiposo branco subcutâneo inguinal e (C) tecido adiposo marrom interescapular após 21 dias de tratamento com veículo, rosiglitazona (4 mg/kg/dia) ou GQ-02 (20 mg/kg/dia) nos camundongos alimentados com DHL. Dados apresentados como média \pm EPM (análise de KruskalWallis seguido pelo pós-teste Dunn); $\mathrm{n}=4-5$ camundongos por grupo. RSG, rosiglitazona 


\section{DISCUSSÃO}

No presente estudo, foi investigado o efeito do GQ-02, um composto sintético derivado de TZD, em cultura de células e in vivo. Em cultura, foi observado efeito adipogênico fraco e, in vivo, efeito antidiabético significativo, semelhante ao da TZD clássica rosiglitazona, acompanhado de perda de peso, perda de massa adiposa, redução da eficiência metabólica e aumento significativo da expressão do gene que codifica UCP1 no TAB visceral.

Estudos in silico conduzidos previamente (138) indicaram que o GQ-02 se liga ao PPAR $\gamma$, fator de transcrição ativado por ligantes que regula a expressão de múltiplos genes envolvidos na adipogênese, sensibilização à insulina, metabolismo lipídico e resposta inflamatória, representando um alvo para o tratamento de resistência insulínica e DM2 (8).

As TZD, como rosiglitazona e pioglitazona, são agonistas totais de PPAR $\gamma$ que possuem efeitos benéficos sobre a homeostase da glicose, aumentando a sensibilidade à insulina e a captação periférica de glicose $(153,154)$. Apesar de sua efetividade no tratamento do DM2, a utilização das TZD tem sido associada a efeitos adversos comuns da classe que incluem ganho de peso (155), retenção hídrica e edema $(117,118,156)$, fraturas ósseas $(115,116)$ e possível aumento do risco de insuficiência cardíaca congestiva (156), limitando seu uso clínico.

Os efeitos adversos das TZD podem ocorrer via ativação suprafisiológica do PPAR $\gamma$ nos tecidos alvo, modulação indesejada da atividade do receptor em variados alvos, ou ser devido a efeitos específicos e peculiares de determinado composto (157), como a hepatotoxicidade idiossincrática associada com a TZD troglitazona (158) que foi motivo para a descontinuidade de seu uso em 1998. Em 2010, a FDA (Food and Drug Administration) restringiu a acesso à TZD rosiglitazona nos Estados Unidos (159) e houve recomendação para sua retirada do mercado na Europa (21) devido a sua associação com risco de infarto do miocárdio (20).

Pequenas moléculas que exibem modo de ligação diferente ao LBD do PPAR $\gamma$, quando comparadas aos agonistas totais, podem resultar na regulação de conjuntos específicos de correguladores e, assim, na expressão diferencial de genes alvo. Choi e cols (2010) constataram que o efeito antidiabético de ligantes de PPAR $\gamma$ 
está associado à inibição da fosforilação, dependente de Cdk5, da serina 273 do PPAR $\gamma$, e não de sua atividade agonista clássica. Estudos subsequentes reforçaram a possibilidade de dissociar o efeito antidiabético de ligantes do PPAR $\gamma$ da atividade agonista clássica no receptor. O GQ-16, composto derivado de TZD com atividade agonista parcial no PPAR $\gamma$, estabiliza a hélice $3(\mathrm{H} 3)$ e regiões da folha $\beta$ do PPAR $\gamma$, apresentando eficácia semelhante à da rosiglitazona em bloquear a fosforilação de Ser $^{273}$ mediada por Cdk5 e em melhorar a sensibilidade insulínica in vivo, com ausência de indução de ganho de peso (23).

$\mathrm{Na}$ tentativa de desenvolver novos ligantes de PPAR $\gamma$ com perfil mais favorável de ação, o GQ-02 foi sintetizado a partir do composto 5-benzilideno-3-(4metil-benzil)-tiazolidina-2,4-diona e estudos de modelagem molecular demonstraram que o complexo formado entre o GQ-02 e o PPAR $\gamma$ apresenta boa estabilidade (energia de ligação negativa) quando comparada com a energia de ligação da rosiglitazona (138). Estudos adicionais in silico demostraram que entre o átomo de oxigênio do anel heterocíclico do GQ-02 e o resíduo Ser ${ }^{289}$ do LBD do PPAR formam-se ligações de hidrogênio, o que estabiliza o receptor e reforça que GQ-02 seja um ligante de PPAR $\gamma(26)$.

Estudos in vivo prévios mostraram os efeitos antidiabéticos e sensibilizadores insulínicos do GQ-02. Mourão e cols (2005) observaram redução dose-dependente da glicemia de jejum e da concentração sérica de triglicerídeos em resposta ao tratamento com GQ-02 (10 e 30 mg/kg/dia, durante 15 dias, por gavagem), em camundongos Swiss de ambos os sexos e com diabetes induzido por aloxano. Costa Leite e cols (2007) confirmaram estes resultados no mesmo modelo. Em camundongos Swiss machos com obesidade e diabetes induzidos por dieta hiperlipídica, foi observado que o tratamento com GQ-02 (20 mg/kg/dia, durante 14 dias, por gavagem) resultou em redução do ganho de peso e da massa adiposa epididimal em resposta à dieta hiperlipídica, sem alterações da ingestão de energia (26). Além disso, foi observado efeito sensibilizador insulínico semelhante ao da rosiglitazona (26).

O efeito do GQ-02 em promover redução do ganho ponderal simultaneamente à inalteração da ingestão de energia sugeriu que o tratamento com este composto se associou à redução da eficiência metabólica que, por sua vez, poderia estar relacionada a aumento do gasto energético. Considerando estes aspectos e a 
capacidade de as TZD induzirem o aumento da expressão de genes relacionados à termogênese no TAB (15), o objetivo do presente trabalho foi investigar os efeitos do derivado de TZD GQ-02 sobre o tecido adiposo, em especial seu efeito em induzir o fenótipo termogênico neste tecido.

O PPAR $\gamma$ é um fator chave na adipogênese e é induzido durante a diferenciação de adipócitos (13,93). As TZD são capazes de iniciar a cascata de sinalização adipogênica em linhagem de células mesenquimais e aumentar a diferenciação de pré-adipócitos em adipócitos (46). No presente estudo, a adipogênese foi estudada em dois tipos celulares, pré-adipócitos 3T3-L1 e células mesenquimais $\mathrm{C} 3 \mathrm{H} 10 \mathrm{~T} 1 / 2$. A TZD rosiglitazona apresentou adipogênese em ambas as linhagens celulares. Essa capacidade adipogênica das TZD é responsável, em parte, pelo efeito adverso conhecido de ganho ponderal in vivo e em seres humanos (157).

O GQ-02 foi capaz de induzir a adipogênese nos pré-adipócitos 3T3-L1, linhagem já comprometida com o processo de diferenciação em adipócitos (141), de forma menos acentuada que a rosiglitazona. Resultado semelhante foi observado com a mesma linhagem celular com o derivado de TZD e agonista parcial de PPAR $\gamma$, GQ-16 (23). Em células mesenquimais C3H10T1/2 não foi observado efeito adipogênico do GQ-02, enquanto que o GQ-16 continuou apresentando potencial adipogênico, ainda que menos acentuado que o da rosiglitazona (23). Estes dados, em conjunto, sugerem que o GQ-02 apresente potencial adipogênico mais fraco que o de um agonista parcial de PPAR $\gamma$ derivado de TZD previamente descrito e compatível com ligantes previamente descritos $(23,160)$.

Para investigação dos efeitos do GQ-02 in vivo, foi utilizada a linhagem isogênica de camundongos C57BI/6, um modelo bem estabelecido para indução de obesidade por dieta $(161,162)$. A exposição prolongada destes animais à dieta altamente calórica, contendo alto teor de lipídeos, é responsável por induzir hiperglicemia e resistência à insulina decorrente da obesidade, possivelmente por predisposição genética (161). Em concordância, os camundongos alimentados por 12 semanas com DHL, desde a $4^{\text {a }}$ semana de vida, apresentaram aumento significativo do peso corporal em relação aos alimentados com DC e desenvolveram hiperglicemia de forma análoga à maioria dos casos em seres humanos, ou seja, em 
indivíduos predispostos que se tornam obesos após acesso a dieta altamente calórica (161).

Os animais alimentados com DHL apresentaram glicemia de jejum de 149,0 \pm 9,27 mg/dL, o que representa valores abaixo dos esperados em relação aos dados observados na literatura com a mesma linhagem de camundongos (161, 162). Ainda assim, estes valores médios são compatíveis com o diagnóstico de DM2 (163). Cabe destacar que os camundongos alimentados com dieta controle apresentaram glicemia média de $114,3 \pm 10,41 \mathrm{mg} / \mathrm{dL}$, compatível com glicemia de jejum alterada (163). Embora este valor esteja acima da faixa de normalidade da glicemia, está de acordo com dados da literatura relacionados a esta linhagem de camundongos (162, 164). Foi previamente descrito que camundongos C57BI/6 machos alimentados com dieta controle acima de 10 semanas de vida, provenientes do Biotério da Faculdade de Medicina da USP, apresentaram glicemia de jejum média de $109 \pm 26,69 \mathrm{mg} / \mathrm{dL}$ (164).

Neste modelo de obesidade e hiperglicemia, o presente estudo demonstrou que o tratamento com GQ-02 na dose de $20 \mathrm{mg} / \mathrm{kg} / \mathrm{dia}$, por via intraperitoneal, durante 3 semanas, reduziu significativamente a glicemia de jejum em animais alimentados com dieta hiperlipídica, em comparação com o veículo. Esta redução foi comparável à observada em resposta ao tratamento com rosiglitazona e resultou em valores semelhantes aos observados em animais alimentados com dieta controle. Estes dados confirmaram os resultados de estudos prévios envolvendo camundongos Swiss com diabetes induzido por aloxano $(25,138)$ e camundongos Swiss com obesidade e diabetes induzidos por dieta hiperlipídica (26). Diferentemente destes últimos estudos, em que o GQ-02 foi administrado por gavagem, neste estudo este composto foi administrado por via intraperitoneal, o que confirmou sua atividade antidiabética também por esta via e descartou a possibilidade de interferência do procedimento de gavagem com variáveis metabólicas, como a glicemia.

As TZD apresentam efeito adverso característico da classe de ganho de peso em roedores e humanos (155). De forma inesperada, não foi observado ganho de peso significativo em resposta ao tratamento com a TZD rosiglitazona. Este resultado poderia ser explicado pelo pequeno número amostral (de animais) em cada grupo experimental ou por problemas relacionados à biodisponibilidade da rosiglitazona administrada pela via peritoneal no presente estudo. O tratamento com 
GQ-02, em contrapartida, promoveu perda de peso nos camundongos com obesidade induzida por DHL, o que sugere que este derivado de TZD não está associado ao efeito adverso de ganho ponderal das TZD clássicas. Efeito semelhante ao do GQ-02, de reduzir a glicemia sem associar-se a ganho de peso, é característico de agonistas parciais/moduladores seletivos de PPAR $\gamma$, como o GQ-16 (23) e MRL24 (22), ou mesmo de ligantes "não agonistas", como o SR1664 (24).

No estudo prévio com camundongos Swiss obesos tratados com GQ-02, foi observada redução do ganho de peso e glicemia em resposta à DHL, porém não perda de peso (26). É possível que a diferença entre este e o presente estudo esteja relacionada ao tempo de tratamento (14 dias no estudo de Mourão e cols, 2006 vs 21 dias no presente estudo), diferenças de biodisponibilidade do GQ-02 administrado por gavagem (no estudo de Mourão e cols, 2006) ou via intraperitoneal (presente estudo), ou mesmo por diferenças nas linhagens e características genéticas de camundongos utilizadas no estudo de Mourão e cols (Swiss) e no presente estudo (C57BI/6).

A perda de peso induzida pelo tratamento com GQ-02 foi acompanhada por redução significativa da energia ingerida. Considerando que no estudo prévio envolvendo camundongos Swiss tratados com GQ-02 foi observada redução do ganho de peso induzido pela DHL acompanhada de inalteração da ingestão de energia (26), o efeito do GQ-02 sobre o peso corporal, observado no presente estudo, não foi atribuído em sua totalidade à redução do consumo alimentar. Para investigar outros mecanismos envolvidos no efeito do GQ-02 sobre o peso, foi calculada a eficiência metabólica, que representada a fração de energia ingerida que é armazenada como reserva energética corporal (165).

No presente estudo, a redução de peso em resposta ao tratamento com GQ02 foi acompanhada de redução da eficiência metabólica, sugerindo o envolvimento de mecanismos adicionais à redução da ingestão de energia. Duas possibilidades foram consideradas: (i) o aumento de perda fecal de energia e (ii) o aumento do gasto energético por indução da termogênese. A primeira, embora não descartada, foi considerada pouco provável considerando a via de administração do GQ-02, intraperitoneal e não gastrointestinal. A segunda possibilidade, plausível. Aumento da termogênese ou produção de calor pode ocorrer em mamíferos em associação com a contração muscular (termogênese induzida por exercício), em decorrência da 
atividade da UCP1 no adipócito marrom ou bege (termogênese adaptativa) ou em associação com a ingestão alimentar (termogênese induzida por dieta) (31).

Há mais de uma década, foi observado que agonistas totais de PPAR $\gamma$, como as TZD, induzem a expressão do transcrito do gene que codifica a UCP1 no tecido adiposo de roedores (166). Subsequentemente, estes agonistas promovem, além do aumento da expressão da UCP1 no TAB, o aumento da biogênese mitocondrial, induzindo características semelhantes às do adipócito marrom no TAB $(14,131)$. O aumento da expressão de genes termogênicos, além de lipolíticos e oxidativos, no TAB é também observado no TAM, in vivo e em cultura, e é semelhante ao que ocorre em resposta à estimulação $\beta 3$-adrenérgica $(12,14)$.

Paradoxalmente, a ativação de PPAR $\gamma$ in vivo promove aumento do armazenamento de energia e ganho de peso, em vez de gasto energético e perda de peso, sugerindo que a regulação da termogênese no tecido adiposo pela ativação completa de PPAR $\gamma$ seja silenciada por ambiente neuronal e hormonal em que o armazenamento energético é favorecido (167).

Considerando os aspectos acima descritos e, ainda, que o PPAR $\gamma$ apresenta expressão elevada no tecido adiposo (19) e que estudos in silico indicaram que o derivado de TZD GQ-02 é um possível ligante de PPAR (138), foi investigado se a perda de peso associada ao tratamento com GQ-02 estaria associada à indução da termogênese no tecido adiposo. Embora não tenha sido avaliado o gasto energético dos camundongos tratados com GQ-02, foram analisadas características que pudessem apontar para fenótipo de atividade termogênica no TAM e no TAB.

No TAM, embora não tenha sido observada alteração da massa do depósito interescapular nos animais tratados com GQ-02, em comparação com os animais tratados com veículo, a análise histológica sugeriu redução do conteúdo lipídico neste depósito, indicado por redução do tamanho das gotículas lipídicas no adipócito marrom. Além disso, foi observado tendência de aumento da expressão do RNAm do gene da Ucp1 neste depósito de TAM. Estas características, indicativas de aumento da atividade deste tecido (52), sugerem a possibilidade de a perda de peso associada ao tratamento com GQ-02 ser devida, pelo menos em parte, à ativação do TAM.

O amarronzamento do TAB, ou recrutamento do adipócito bege, em resposta a agonistas de PPAR $\gamma$ ocorre preferencialmente no TAB subcutâneo e é 
determinado por aumento dos níveis de PRDM16 (15), corregulador da transcrição crítico para a diferenciação de adipócitos bege. É possível, porém, que ocorra também amarronzamento do TAB visceral, em decorrência de características da linhagem de animais estudada. Fukui e cols (2000) demonstraram indução da expressão de Ucp1 no tecido adiposo branco mesentérico (depósito visceral) em resposta a composto derivado de TZD e dados do Laboratório de Farmacologia Molecular (não publicados) envolvendo outro derivado de TZD, o GQ-16, também mostraram indução da expressão genes relacionados à termogênese (Ucp1 e Cidea) no TAB epididimal em camundongos Swiss heterogênicos.

No presente estudo, no TAB visceral, foi observada redução significativa da massa do TAB epididimal nos animais tratados com GQ-02. A análise histológica sugeriu que esta redução foi acompanhada de tendência de redução do diâmetro dos adipócitos neste depósito em resposta ao tratamento com este derivado de TZD. Estes achados poderiam sugerir aumento da lipólise e termogênese no TAB visceral. Para investigar estes aspectos, foi analisado o consumo de oxigênio do TAB epididimal e observado que os animais tratados com GQ-02 apresentaram tendência de aumento desta variável, quando comparados aos tratados com veículo ou rosiglitazona. A expressão do RNAm do gene da Ucp1 também foi analisada no depósito visceral de TAB e foi observado aumento significativo com tratamento com GQ-02 em relação à expressão do RNAm no grupo tratado com veículo.

Não foram observadas alterações da massa de TAB inguinal (depósito subcutâneo), de suas características histológicas, da taxa de consumo de oxigênio neste depósito ou da expressão de Ucp1 entre os diferentes tratamentos, sugerindo que eventuais efeitos do GQ-02 sobre este depósito de TAB não estejam envolvidos nos efeitos deste composto sobre o peso.

É plausível, ainda, hipotetizar efeito do GQ-02 no SNC para explicar seu efeito sobre o peso. O PPAR $\gamma$ é expresso em áreas do cérebro envolvidas com a homeostase de glicose e o metabolismo energético (108) e ativação desse receptor está envolvida na regulação do balanço energético (109). O nocaute do PPAR $\gamma$ em áreas específicas do cérebro de camundongos resulta em proteção contra a obesidade induzida por dieta por promover aumento do gasto energético e redução da ingestão de energia (109), além de aumento da sensibilidade à leptina (109), adipocina envolvida na regulação do balanço energético. 
Considerando que o GQ-02 apresenta estrutura química derivada de TZD (25), é possível que, à semelhança das TZD, apresentasse capacidade de atravessar a barreira encefálica de maneira similar às TZD porém, no SNC, modulasse a atividade do PPAR $\gamma$ de forma distinta que resultasse em aumento do gasto energético. É possível, ainda, que à semelhança das TZD induzisse a expressão de genes relacionados à termogênese por ação direta sobre o TAM e TAB, porém, de maneira distinta das TZD, não influenciasse mecanismos neuronais envolvidos na redução do gasto energético e na falta de expressão da atividade termogênica no tecido adiposo (167).

Outra hipótese a ser considerada para explicar a redução do peso e da ingestão de alimentos nos animais tratados com GQ-02 é a possível toxicidade deste composto. Embora esta possibilidade seja pouco provável com base em estudos prévios em que foram utilizadas doses iguais ou superiores do GQ-02 e não foi descrita toxicidade $(25,26,139)$, algumas características analisadas no presente estudo sugerem que não tenha havido toxicidade associada ao tratamento com GQ02. Não foram observadas alterações histológicas hepáticas sugestivas de toxicidade, nem alterações da massa cardíaca, renal ou testicular nos animais tratados com o composto, em relação aos demais grupos. As características histológicas do fígado, ao contrário, sugeririam efeito favorável do GQ-02 neste modelo animal.

A obesidade e resistência à insulina promovem, no fígado, aumento do fluxo de ácidos graxos livres com consequente acúmulo lipídico nos hepatócitos (98), em concordância com a observação, no presente estudo, de que os animais que receberam dieta hiperlipídica e foram tratados com veículo apresentaram características histológicas sugestivas de acúmulo lipídico no fígado em comparação com aqueles alimentados com dieta controle.

Ativação de PPAR $\gamma$, em camundongos, promove esteatose hepática por indução da expressão de genes lipogênicos $(98,137)$, enquanto que a inativação específica do PPAR $\gamma$ no fígado, em camundongos com obesidade induzida por dieta, reduz a esteatose hepática (98). Rull e cols (2014) descreveram significante esteatose hepática e aumento do conteúdo de triglicerídeos no fígado de camundongos tratados com rosiglitazona. Em concordância, no presente estudo foi observado aumento do acúmulo lipídico nos hepatócitos de camundongos tratados 
com rosiglitazona, em comparação com animais tratados com veículo. Não houve, contudo, correspondente aumento do conteúdo quantitativo de triglicerídeos no fígado. Os resultados discordantes entre a análise histológica e o conteúdo hepático de triglicerídeos podem ser devidos ao reduzido número amostral em cada grupo experimental.

O efeito positivo do GQ-02 sobre a esteatose hepática foi previamente descrito em outro modelo. Silva e cols (2015) estudaram camundongos C57BI/6 nocautes para o gene do receptor de LDL (LDLR-/-) tratados com GQ-02 na dose de $30 \mathrm{mg} / \mathrm{kg} / \mathrm{dia}$. Foi observado que este derivado de TZD melhorou a esteatose hepática em relação ao tratamento com veículo e esta melhora foi caracterizada por diminuição da vacuolização e de infiltrados inflamatórios, melhor organização do parênquima hepático e redução do conteúdo de lipídeos no fígado (140).

Os resultados do presente estudo, em conjunto, sugerem que o GQ-02 apresenta efeito antidiabético semelhante ao das TZD clássicas, porém não associado a ganho peso, mas sim a perda de peso em animais alimentados com dieta hiperlipídica. Alguns resultados sugerem que seu efeito sobre o peso possa estar relacionado a aumento do gasto energético, incluindo (i) a redução da eficiência metabólica, (ii) a redução do conteúdo lipídico e tendência de aumento da expressão de Ucp1 no TAM e (iii) a redução da massa adiposa visceral acompanhada de tendência de aumento da taxa de consumo de oxigênio neste depósito de TAB e de aumento significativo da expressão de Ucp1. Estes efeitos, embora careçam de caracterização mais detalhada em estudos futuros, sugerem seu potencial como estratégia terapêutica para a obesidade e DM2.

Podemos, ainda, ressalvar algumas limitações do presente estudo, que incluem reduzido número amostral nos estudos in vivo; ausência da análise de perda fecal de gordura como mecanismo para explicar a redução da eficiência metabólica; ausência da análise de consumo de oxigênio por calorimetria indireta; ausência de análise quantitativa do diâmetro dos adipócitos nas lâminas histológicas; ausência da análise de genes relacionados à lipólise, outros genes termogênicos ou ainda de genes do adipócito bege; e ausência da análise da expressão proteica da UCP1.

É importante destacar que os efeitos do GQ-02 sobre o PPAR $\gamma$ precisam ainda ser explorados. Estudos prévios conduzidos no Laboratório de Farmacologia Molecular da Universidade de Brasília (dados não mostrados) não caracterizaram o GQ-02 como agonista ou antagonista de PPAR em ensaios de gene repórter, 
porém seu efeito sobre modificações pós-traducionais do receptor, que poderiam estar associadas à indução do fenótipo termogênico no TAB (15), ainda não foram investigados. 


\section{CONCLUSÃO}

Em cultura de células, o GQ-02:

- Apresentou potencial adipogênico fraco em pré-adipócitos murinos 3T3-L1 induzidos a se diferenciar com IBMX, dexametasona e insulina e induzidos a se diferenciar apenas com insulina;

- Não apresentou potencial adipogênico em células mesenquimais murinas C3H10T1/2 induzidas a se diferenciar com IBMX, dexametasona e insulina.

Em camundongos C57BI/6 alimentados com DHL, o tratamento com GQ-02:

- Reduziu a glicemia de jejum com magnitude semelhante à RSG;

- Induziu perda de peso e redução da eficiência metabólica;

- Reduziu a massa adiposa visceral e o tamanho do adipócito no TAB epididimal, e resultou em tendência de aumento do consumo de oxigênio deste depósito visceral;

- Não modificou as características histológicas do TAB inguinal (subcutâneo);

- Reduziu o acúmulo lipídico no TAM, sem alteração da massa adiposa ou do consumo de oxigênio deste depósito;

- Resultou em tendência de aumento da expressão do RNAm do gene Ucp1 no TAM e em aumento significativo no TAB epididimal (visceral);

- Não alterou as massas cardíaca, renal ou testicular;

- Reduziu o acúmulo lipídico no fígado (esteatose hepática). 


\section{REFERÊNCIAS}

1. Santos GM, Neves $F$ de A, Amato AA. Thermogenesis in white adipose tissue: An unfinished story about PPARgamma. Biochim Biophys Acta. 2015;1850(4):691-5.

2. World Health Organization: WHO [homepage na internet]. Obesity and overweight. Fact sheet №311. Updated January 2015 [Acesso em 23 dez de 2015]. Disponível em: http://www.who.int/mediacentre/factsheets/fs311/en/

3. Brasil. Ministério da Saúde. Secretaria de Vigilância em Saúde. Departamento de Vigilância de Doenças e Agravos não Transmissíveis e Promoção da Saúde. Vigitel Brasil 2014: vigilância de fatores de risco e proteção para doenças crônicas por inquérito telefônico. Brasília: Ministério da Saúde; 2015:44-51.

4. World Health Organization. Obesity: preventing and managing the global epidemic. Report of a World Health Organization Consultation. WHO Obesity Technical Report Series. WHO; 2000:6-15.

5. Kopelman PG. Obesity as a medical problem. Nature. 2000; 404(6778):635-43.

6. Burgio E, Lopomo A, Migliore L. Obesity and diabetes: from genetics to epigenetics. Mol Biol Rep. 2015; 42(4):799-818.

7. World Health Organization. Definition, Diagnosis and Classification of Diabetes Mellitus and its Complications. Report of a World Health Organization Consultation. WHO Department on Noncommunicable Disease Surveillance. Genebra:WHO; 1999:1-7.

8. Liu C, Feng T, Zhu N, Liu P, Han X, Chen M, et al. Identification of a novel selective agonist of PPARy with no promotion of adipogenesis and less inhibition of osteoblastogenesis. Sci Rep. 2015; 5:9530.

9. Barbatelli G, Murano I, Madsen L, Hao Q, Jimenez M, Kristiansen K, et al. The emergence of cold-induced brown adipocytes in mouse white fat depots is determined predominantly by white to brown adipocyte transdifferentiation. Am J Physiol Endocrinol Metab. 2010; 298(6):E1244-53.

10. Cousin B, Cinti S, Morroni M, Raimbault S, Ricquier D, Pénicaud L, et al. Occurrence of brown adipocytes in rat white adipose tissue: molecular and morphological characterization. J Cell Sci. 1992; 103(Pt 4):931-42.

11. Saito M, Okamatsu-Ogura Y, Matsushita M, Watanabe K, Yoneshiro T, NioKobayashi J, et al. High incidence of metabolically active brown adipose tissue in healthy adult humans: effects of cold exposure and adiposity. Diabetes. 2009; 58(7):1526-31.

12. Wu J, Boström P, Sparks LM, Ye L, Choi JH, Giang AH, et al. Beige adipocytes are a distinct type of thermogenic fat cell in mouse and human. Cell. 2012; 150(2):366-76.

13. Tontonoz P, Hu E, Spiegelman BM. Stimulation of adipogenesis in fibroblasts by PPAR gamma 2, a lipid-activated transcription factor. Cell. 1994; 79(7):1147-56.

14. Petrovic N, Walden TB, Shabalina IG, Timmons JA, Cannon B, Nedergaard J. Chronic peroxisome proliferator-activated receptor gamma (PPARgamma) activation of epididymally derived white adipocyte cultures reveals a population of 
thermogenically competent, UCP1-containing adipocytes molecularly distinct from classic brown adipocytes. J Biol Chem. 2010; 285(10):7153-64.

15. Ohno H, Shinoda K, Spiegelman BM, Kajimura S. PPARgamma agonists induce a white-to-brown fat conversion through stabilization of PRDM16 protein. Cell Metab. 2012; 15(3):395-404.

16. Seale P, Bjork B, Yang W, Kajimura S, Chin S, Kuang S, et al. PRDM16 controls a brown fat/skeletal muscle switch. Nature. 2008; 454(7207):961-7.

17. Cohen P, Levy JD, Zhang Y, Frontini A, Kolodin DP, Svensson KJ, et al. Ablation of PRDM16 and beige adipose causes metabolic dysfunction and a subcutaneous to visceral fat switch. Cell. 2014; 156(1-2):304-16.

18. Samuel VT, Petersen KF, Shulman Gl. Lipid-induced insulin resistance: unravelling the mechanism. Lancet. 2010; 375(9733):2267-77.

19. Ahmadian M, Suh JM, Hah N, Liddle C, Atkins AR, Downes $M$, et al. PPARgamma signaling and metabolism: the good, the bad and the future. Nat Med. 2013; 19(5):557-66.

20. Nissen SE, Wolski K. Effect of rosiglitazone on the risk of myocardial infarction and death from cardiovascular causes. N Engl J Med. 2007; 356(24):2457-71.

21. European Medicines Agency [homepage]. Agency recommends suspension of Avandia, Avandamet and Avaglim. 2010. [Acesso em 10 jan 2015]. Disponível em: http://www.ema.europa.eu/ema/index.jsp?curl=pages/ news_and_events/news/2010/09/news_detail_001119.jsp

22. Choi JH, Banks AS, Estall JL, Kajimura S, Boström P, Laznik D, et al. Obesitylinked phosphorylation of PPARy by cdk5 is a direct target of the anti-diabetic PPARy ligands. Nature. 2010; 466(7305):451-6.

23. Amato AA, Rajagopalan S, Lin JZ, Carvalho BM, Figueira AC, Lu J, et al. GQ-16, a novel peroxisome proliferator-activated receptor $\mathrm{Y}$ (PPARy) ligand, promotes insulin sensitization without weight gain. J Biol Chem. 2012; 287(33):28169-79

24. Choi JH, Banks AS, Kamenecka TM, Busby SA, Chalmers MJ, Kumar N, et al. Antidiabetic actions of a non-agonist PPARy ligand blocking Cdk5-mediated phosphorylation. Nature. 2011; 477(7365):477-81.

25. Mourão RH, Silva TG, Soares AL, Vieira ES, Santos JN, Lima MC, et al. Synthesis and biological activity of novel acridinylidene and benzylidene thiazolidinediones. Eur J Med Chem. 2005; 40(11):1129-33.

26. Mourão RHV. Síntese, Modelagem Molecular e Atividade Hipoglicemiante de Novas Arilideno-Tiazolidinadionas. Recife. Tese [Doutorado em Ciências Biológicas] - Universidade Federal de Pernambuco; 2006.

27. Kelly T, Yang W, Chen CS, Reynolds K, He J. Global burden of obesity in 2005 and projections to 2030. Int J Obes (Lond). 2008; 32(9):1431-7.

28. Ng M, Fleming T, Robinson M, Thomson B, Graetz N, Margono C, et al. Global, regional, and national prevalence of overweight and obesity in children and adults during 1980-2013: a systematic analysis for the Global Burden of Disease Study 2013. Lancet. 2014; 384(9945):766-81.

29. Serra D, Mera P, Malandrino MI, Mir JF, Herrero L. Mitochondrial fatty acid oxidation in obesity. Antioxid Redox Signal. 2013; 19(3):269-84.

30. Chechi K, Nedergaard J, Richard D. Brown adipose tissue as an anti-obesity tissue in humans. Obes Rev. 2014; 15(2):92-106. 
31. Harms M, Seale P. Brown and beige fat: development, function and therapeutic potential. Nat Med. 2013; 19(10):1252-63.

32. Christian M, Parker MG. The engineering of brown fat. J Mol Cell Biol. 2010; $2(1): 23-5$.

33. Dhurandhar EJ, Keith SW. The aetiology of obesity beyond eating more and exercising less. Best Pract Res Clin Gastroenterol. 2014; 28(4):533-44.

34.Zhang Y, Proenca R, Maffei M, Barone M, Leopold L, Friedman JM. Positional cloning of the mouse obese gene and its human homologue. Nature. 1994; 372(6505):425-32.

35. Kershaw EE, Flier JS. Adipose tissue as an endocrine organ. J Clin Endocrinol Metab. 2004; 89(6):2548-56.

36. Collins S. Overview of clinical perspectives and mechanisms of obesity. Birth Defects Res A Clin Mol Teratol. 2005; 73(7):470-1.

37. Ouchi N, Parker JL, Lugus JJ, Walsh K. Adipokines in inflammation and metabolic disease. Nat Rev Immunol. 2011; 11(2):85-97.

38. Sun K, Kusminski CM, Scherer PE. Adipose tissue remodeling and obesity. J Clin Invest. 2011; 121(6):2094-101.

39. Lumeng CN, Bodzin JL, Saltiel AR. Obesity induces a phenotypic switch in adipose tissue macrophage polarization. J Clin Invest. 2007; 117(1):175-84.

40.Gordon S. Alternative activation of macrophages. Nat Rev Immunol. 2003; 3(1):23-35.

41. Odegaard JI, Chawla A. Alternative macrophage activation and metabolism. Annu Rev Pathol. 2011; 6:275-97.

42. Nishimura S, Manabe I, Nagasaki M, Seo K, Yamashita $\mathrm{H}$, et al. In vivo imaging in mice reveals local cell dynamics and inflammation in obese adipose tissue. $\mathrm{J}$ Clin Invest. 2008; 118(2):710-21.

43. Cinti S, Mitchell G, Barbatelli G, Murano I, Ceresi E, Faloia E, et al. Adipocyte death defines macrophage localization and function in adipose tissue of obese mice and humans. J Lipid Res. 2005; 46(11):2347-55.

44. Rosenwald M, Perdikari A, Rülicke T, Wolfrum C. Bi-directional interconversion of brite and white adipocytes. Nat Cell Biol. 2013; 15(6):659-67.

45. Attie AD, Scherer PE. Adipocyte metabolism and obesity. J Lipid Res. 2009; 50 Suppl:S395-9.

46. Seale P, Kajimura S, Spiegelman BM. Transcriptional control of brown adipocyte development and physiological function -- of mice and men. Genes Dev. 2009; 23(7):788-97.

47. Seale P, Conroe HM, Estall J, Kajimura S, Frontini A, Ishibashi J, et al. Prdm16 determines the thermogenic program of subcutaneous white adipose tissue in mice. J Clin Invest. 2011; 121(1):96-105.

48. Spiegelman BM. Banting Lecture 2012: Regulation of adipogenesis: toward new therapeutics for metabolic disease. Diabetes. 2013; 62(6):1774-82.

49. Frontini A, Cinti S. Distribution and development of brown adipocytes in the murine and human adipose organ. Cell Metab. 2010; 11(4):253-6.

50. Farmer SR. Transcriptional control of adipocyte formation. Cell Metab. 2006; 4(4):263-73. 
51. Klingenspor M, Fromme T. Brown adipose tissue. In: Symonds ME. Adipose tissue biology. Germany: Springer New York; 2011:39-69.

52. Cannon B, Nedergaard J. Brown adipose tissue: function and physiological significance. Physiol Rev. 2004; 84(1):277-359.

53. Sharp LZ, Shinoda K, Ohno H, Scheel DW, Tomoda E, Ruiz L, et al. Human BAT possesses molecular signatures that resemble beige/brite cells. PLoS One. 2012; 7(11):e49452.

54. Wu J, Cohen P, Spiegelman BM. Adaptive thermogenesis in adipocytes: is beige the new brown? Genes Dev. 2013; 27(3):234-50.

55. Rosen ED, Spiegelman BM. What we talk about when we talk about fat. Cell. $2014 ; 156(1-2): 20-44$.

56. Timmons JA, Wennmalm K, Larsson O, Walden TB, Lassmann T, Petrovic N, et al. Myogenic gene expression signature establishes that brown and white adipocytes originate from distinct cell lineages. Proc Natl Acad Sci U S A. 2007; 104(11):4401-6.

57. Wang QA, Tao C, Gupta RK, Scherer PE. Tracking adipogenesis during white adipose tissue development, expansion and regeneration. Nat Med. 2013; 19(10):1338-44.

58. Rosen ED, Spiegelman BM. Molecular regulation of adipogenesis. Annu Rev Cell Dev Biol. 2000; 16:145-71.

59. Cao W, Daniel KW, Robidoux J, Puigserver P, Medvedev AV, Bai X, et al. p38 mitogen-activated protein kinase is the central regulator of cyclic AMP-dependent transcription of the brown fat uncoupling protein 1 gene. Mol Cell Biol. 2004; 24(7):3057-67.

60. Cao W, Medvedev AV, Daniel KW, Collins S. beta-Adrenergic activation of p38 MAP kinase in adipocytes: Camp induction of the uncoupling protein 1 (UCP1) gene requires p38 MAP kinase. J Biol Chem. 2001; 276(29):27077-82.

61. Leone TC, Lehman JJ, Finck BN, Schaeffer PJ, Wende AR, Boudina S, et al. PGC-1 alpha deficiency causes multi-system energy metabolic derangements: muscle dysfunction, abnormal weight control and hepatic steatosis. PloS Biol. 2005; 3(4):e101.

62. Uldry M, Yang W, St-Pierre J, Lin J, Seale P, Spiegelman BM. Complementary action of the PGC-1 coactivators in mitochondrial biogenesis and brown fat differentiation. Cell Metab. 2006; 3(5):333-41.

63. Kleiner S, Mepani RJ, Laznik D, Ye L, Jurczak MJ, Jornayvaz FR, et al. Development of insulin resistance in mice lacking PGC-1a in adipose tissues. Proc Natl Acad Sci U S A. 2012; 109(24):9635-40.

64. Ibrahim MM. Subcutaneous and visceral adipose tissue: structural and functional differences. Obes Rev. 2010; 11(1):11-8.

65. Pischon T, Boeing H, Hoffmann K, Bergmann M, Schulze MB, Overvad K, et al. General and abdominal adiposity and risk of death in Europe. N. Engl. J. Med. 2008; 359:2105-2120.

66. Manolopoulos KN, Karpe F, Frayn KN. Gluteofemoral body fat as a determinant of metabolic health. Int. J. Obes. 2010; 34:949-959. 
67. Tiraby C, Tavernier G, Lefort C, Larrouy D, Bouillaud F, Ricquier D, et al. Acquirement of brown fat cell features by human white adipocytes. $J$ Biol Chem. 2003; 278(35):33370-6.

68. Nedergaard J, Bengtsson T, Cannon B. Unexpected evidence for active brown adipose tissue in adult humans. Am J Physiol Endocrinol Metab. 2007; 293(2):E444-52.

69. Cypess AM, Lehman S, Williams G, Tal I, Rodman D, Goldfine AB, et al. Identification and importance of brown adipose tissue in adult humans. $\mathrm{N}$ Engl J Med. 2009; 360(15):1509-17.

70. van Marken Lichtenbelt WD, Vanhommerig JW, Smulders NM, Drossaerts JM, Kemerink GJ, Bouvy ND, et al. Cold-activated brown adipose tissue in healthy men. N Engl J Med. 2009; 360(15):1500-8.

71. Bartelt A, Heeren J. Adipose tissue browning and metabolic health. Nat Rev Endocrinol. 2014; 10(1):24-36.

72. Lidell ME, Betz MJ, Leinhard OD, Heglind M, Elander L, Slawik M, et al. Evidence for two types of brown adipose tissue in humans. Nat. Med. 2013; 19:631-634.

73. Cypess AM, White AP, Vernochet C, Schulz TJ, Xue R, Sass CA, et al. Anatomical localization, gene expression profiling and functional characterization of adult human neck brown fat. Nat. Med. 2013; 19:635-639.

74. Jespersen NZ, Larsen TJ, Peijs L, Daugaard S, Homoe P, Loft A, et al. A classical brown adipose tissue mRNA signature partly overlaps with brite in the supraclavicular region of adult humans. Cell Metab. 2013; 17:798-805.

75. Sladek FM. What are nuclear receptor ligands? Mol Cell Endocrinol. 2011; 334(12):3-13.

76. King N, Westbrook MJ, Young SL, Kuo A, Abedin M, Chapman J, et al. The genome of the choanoflagellate Monosiga brevicollis and the origin of metazoans. Nature. 2008; 451:783-788.

77. Burris TP, Solt LA, Wang Y, Crumbley C, Banerjee S, Griffett K, et al. Nuclear receptors and their selective pharmacologic modulators. Pharmacol Rev. 2013; 65(2):710-78.

78. Gelman L, Feige JN, Desvergne B. Molecular basis of selective PPARgamma modulation for the treatment of Type 2 diabetes. Biochim Biophys Acta. 2007; 1771(8):1094-107.

79. Glass CK. Going nuclear in metabolic and cardiovascular disease. J Clin Invest. 2006; 116(3):556-60.

80. Wurtz JM, Bourguet W, Renaud JP, Vivat V, Chambon P, Moras D, et al. A canonical structure for the ligand-binding domain of nuclear receptors. Nat Struct Biol. 1996; 3(1):87-94.

81. Evans RM, Barish GD, Wang YX. PPARs and the complex journey to obesity. Nat Med. 2004; 10(4):355-61

82. Cariou B, Charbonnel B, Staels B. Thiazolidinediones and PPARgamma agonists: time for a reassessment. Trends Endocrinol Metab. 2012;23(5):205-15.

83. Amato AA, de Assis Rocha Neves F. Idealized PPARgamma-Based Therapies: Lessons from Bench and Bedside. PPAR Res. 2012; 2012:978687. 
84.Zoete V, Grosdidier A, Michielin O. Peroxisome proliferator-activated receptor structures: ligand specificity, molecular switch and interactions with regulators. Biochim Biophys Acta. 2007; 1771(8):915-25.

85. Garcia-Vallvé S, Guasch L, Tomas-Hernández S, del Bas JM, Ollendorff V, Arola L, et al. Peroxisome Proliferator-Activated Receptor Gamma (PPARgamma) and Ligand Choreography: Newcomers Take the Stage.J Med Chem. 2015; 58(14):5381-94.

86. Jennewein C, von Knethen A, Schmid T, Brüne B. MicroRNA-27b contributes to lipopolysaccharide-mediated peroxisome proliferator-activated receptor gamma (PPARgamma) mRNA destabilization. J Biol Chem. 2010; 285(16):11846-53.

87. Rosen ED, Walkey CJ, Puigserver P, Spiegelman BM. Transcriptional regulation of adipogenesis. Genes Dev. 2000; 14(11):1293-307.

88. Fajas L, Auboeuf D, Raspe E, Schoonjans K, Lefebvre AM, Saladin R, et al. The organization, promoter analysis, and expression of the human PPARgamma gene. J Biol Chem. 1997; 272(30):18779-89.

89. Wu Z, Rosen ED, Brun R, Hauser S, Adelmant G, Troy AE, et al. Crossregulation of $\mathrm{C} / \mathrm{EBP}$ alpha and PPAR gamma controls the transcriptional pathway of adipogenesis and insulin sensitivity. Mol Cell. 1999; 3(2):151-8.

90. Tai TA, Jennermann C, Brown KK, Oliver BB, MacGinnitie MA, Wilkison WO, et al. Activation of the nuclear receptor peroxisome proliferator-activated receptor gamma promotes brown adipocyte differentiation. J Biol Chem. 1996; 271(47):29909-14.

91. Kajimura S, Seale P, Tomaru T, Erdjument-Bromage H, Cooper MP, Ruas JL, et al. Regulation of the brown and white fat gene programs through a PRDM16/CtBP transcriptional complex. Genes Dev. 2008; 22(10):1397-409.

92. Kajimura S, Seale P, Kubota K, Lunsford E, Frangioni JV, Gygi SP, et al. Initiation of myoblast to brown fat switch by a PRDM16-C/EBP-beta transcriptional complex. Nature. 2009; 460(7259):1154-8.

93.Tontonoz P, Spiegelman BM. Fat and beyond: the diverse biology of PPARgamma. Annu Rev Biochem. 2008; 77:289-312.

94. Yu JG, Javorschi S, Hevener AL, Kruszynska YT, Norman RA, Sinha M, et al. The effect of thiazolidinediones on plasma adiponectin levels in normal, obese, and type 2 diabetic subjects. Diabetes. 2002; 51(10):2968-74.

95. Nawrocki AR, Rajala MW, Tomas E, Pajvani UB, Saha AK, Trumbauer ME, et al. Mice lacking adiponectin show decreased hepatic insulin sensitivity and reduced responsiveness to peroxisome proliferator-activated receptor gamma agonists. J Biol Chem. 2006; 281(5):2654-60.

96. Burant CF, Sreenan S, Hirano K, Tai TA, Lohmiller J, Lukens J, et al. Troglitazone action is independent of adipose tissue. J Clin Invest. 1997; 100(11):2900-8.

97. Kim JK, Fillmore JJ, Gavrilova O, Chao L, Higashimori T, Choi H, et al. Differential effects of rosiglitazone on skeletal muscle and liver insulin resistance in A-ZIP/F-1 fatless mice. Diabetes. 2003; 52(6):1311-8.

98. Gavrilova O, Haluzik M, Matsusue K, Cutson JJ, Johnson L, Dietz KR, et al. Liver peroxisome proliferator-activated receptor gamma contributes to hepatic 
steatosis, triglyceride clearance, and regulation of body fat mass. J Biol Chem. 2003; 278(36):34268-76.

99. Morán-Salvador E, López-Parra M, García-Alonso V, Titos E, Martínez-Clemente M, González-Périz A, et al. Role for PPARgamma in obesity-induced hepatic steatosis as determined by hepatocyte- and macrophage-specific conditional knockouts. FASEB J. 2011; 25(8):2538-50.

100. Belfort R, Harrison SA, Brown K, Darland C, Finch J, Hardies J, et al A placebocontrolled trial of pioglitazone in subjects with nonalcoholic steatohepatitis. $\mathrm{N}$ Engl J Med. 2006; 355(22):2297-307.

101. Ratziu V, Giral P, Jacqueminet S, Charlotte F, Hartemann-Heurtier A, Serfaty L, et al. Rosiglitazone for nonalcoholic steatohepatitis: one-year results of the randomized placebo-controlled Fatty Liver Improvement with Rosiglitazone Therapy (FLIRT) Trial. Gastroenterology. 2008; 135(1):100-10.

102. Mayerson AB, Hundal RS, Dufour S, Lebon V, Befroy D, Cline GW, et al. The effects of rosiglitazone on insulin sensitivity, lipolysis, and hepatic and skeletal muscle triglyceride content in patients with type 2 diabetes. Diabetes. 2002; 51(3):797-802.

103. Kallwitz ER, McLachlan A, Cotler SJ. Role of peroxisome proliferators-activated receptors in the pathogenesis and treatment of nonalcoholic fatty liver disease. World J Gastroenterol. 2008; 14(1):22-8.

104. Bouhlel MA, Derudas B, Rigamonti E, Dièvart R, Brozek J, Haulon S, et al. PPARgamma activation primes human monocytes into alternative M2 macrophages with anti-inflammatory properties. Cell Metab. 2007; 6(2):137-43.

105. Hevener AL, Olefsky JM, Reichart D, Nguyen MT, Bandyopadyhay G, Leung HY, et al. Macrophage PPARgamma is required for normal skeletal muscle and hepatic insulin sensitivity and full antidiabetic effects of thiazolidinediones. J Clin Invest. 2007; 117(6):1658-69.

106. Odegaard JI, Ricardo-Gonzalez RR, Goforth MH, Morel CR, Subramanian V, Mukundan L, et al. Macrophage-specific PPARgamma controls alternative activation and improves insulin resistance.Nature. 2007; 447(7148):1116-20.

107. Li AC, Brown KK, Silvestre MJ, Willson TM, Palinski W, Glass CK. Peroxisome proliferator-activated receptor gamma ligands inhibit development of atherosclerosis in LDL receptor-deficient mice. J Clin Invest. 2000; 106(4):52331.

108. Ryan KK, Li B, Grayson BE, Matter EK, Woods SC, Seeley RJ. A role for central nervous system PPARgamma in the regulation of energy balance. Nat Med. 2011; 17(5):623-6.

109. Lu M, Sarruf DA, Talukdar S, Sharma S, Li P, Bandyopadhyay G, et al. Brain PPARgamma promotes obesity and is required for the insulin-sensitizing effect of thiazolidinediones. Nat Med. 2011; 17(5):618-22.

110. Kelly T, Yang W, Chen CS, Reynolds K, He J. Global burden of obesity in 2005 and projections to 2030. Int J Obes. 2008; 32(9):1431-7.

111. Nakamura T, Funahashi T, Yamashita S, Nishida M, Nishida Y, Takahashi M, et al. Thiazolidinedione derivative improves fat distribution and multiple risk factors in subjects with visceral fat accumulation - double-blind placebo-controlled trial. Diabetes Res Clin Pract. 2001; 54(3):181-90. 
112. Miyazaki Y, Mahankali A, Matsuda M, Mahankali S, Hardies J, Cusi K, et al. Effect of pioglitazone on abdominal fat distribution and insulin sensitivity in type 2 diabetic patients. J Clin Endocrinol Metab. 2002; 87(6):2784-91.

113. Kung J, Henry RR. Thiazolidinedione safety. Expert Opin Drug Saf. 2012; 11(4):565-79.

114. Betteridge DJ. Thiazolidinediones and fracture risk in patients with type 2 diabetes. Diabet Med. 2011; 28(7):759-71.

115. Wan Y. PPARgamma in bone homeostasis. Trends Endocrinol Metab. 2010; 21(12):722-8.

116. Wei W, Wan Y. Thiazolidinediones on PPARgamma: the roles in bone remodeling. PPAR Res. 2011; 2011:867180.

117. Zhang H, Zhang A, Kohan DE, Nelson RD, Gonzalez FJ, Yang T. Collecting duct-specific deletion of peroxisome proliferator-activated receptor gamma blocks thiazolidinedione-induced fluid retention. Proc Natl Acad Sci USA. 2005; 102(26):9406-11.

118. Guan Y, Hao C, Cha DR, Rao R, Lu W, Kohan DE, et al. Thiazolidinediones expand body fluid volume through PPARgamma stimulation of EnaC-mediated renal salt absorption. Nat Med. 2005; 11(8):861-6.

119. Yamakawa K, Hosoi M, Koyama H, Tanaka S, Fukumoto S, Morii H, et al. Peroxisome proliferator-activated receptor-gamma agonists increase vascular endothelial growth factor expression in human vascular smooth muscle cells. Biochem Biophys Res Commun. 2000; 271(3):571-4.

120. Duan SZ, Ivashchenko CY, Russell MW, Milstone DS, Mortensen RM. Cardiomyocyte-specific knockout and agonist of peroxisome proliferatoractivated receptor-gamma both induce cardiac hypertrophy in mice. Circ Res. 2005; 97(4):372-9.

121. Nissen SE, Wolski K. Rosiglitazone revisited: an updated meta-analysis of risk for myocardial infarction and cardiovascular mortality. Arch Intern Med. 2010; 170(14):1191-1201.

122. Wilcox R, Kupfer S, Erdmann E. Effects of pioglitazone on major adverse cardiovascular events in high-risk patients with type 2 diabetes: results from PROspective pioglitazone Clinical Trial In macro Vascular Events. Am Heart J. 2008; 155(4):712-7.

123. Lincoff AM, Wolski K, Nicholls SJ, Nissen SE. Pioglitazone and risk of cardiovascular events in patients with type 2 diabetes mellitus: a meta-analysis of randomized trials. JAMA. 2007; 298(10):1180-8.

124. Azoulay L, Yin H, Filion KB, Assayag J, Majdan A, Pollak MN, et al. The use of pioglitazone and the risk of bladder cancer in people with type 2 diabetes: nested case-control study. BMJ. 2012; 344:e3645.

125. Neumann A, Weill A, Ricordeau P, Fagot JP, Alla F, Allemand H. Pioglitazone and risk of bladder cancer among diabetic patients in France: a population-based cohort study. Diabetologia. 2012; 55(7):1953-62.

126. Schupp M, Lazar MA. Endogenous ligands for nuclear receptors: digging deeper. J Biol Chem. 2010; 285(52):40409-15. 
127. Bruning JB, Chalmers MJ, Prasad S, Busby SA, Kamenecka TM, He Y, et al. Partial agonists activate PPARgamma using a helix 12 independent mechanism. Structure. 2007; 15(10):1258-71.

128. Sauer S. Ligands for the Nuclear Peroxisome Proliferator-Activated Receptor Gamma. Trends Pharmacol Sci. 2015; 36(10):688-704.

129. Balint BL, Nagy L. Selective modulators of PPAR activity as new therapeutic tools in metabolic diseases. Endocr Metab Immune Disord Drug Targets. 2006; 6(1):33-43.

130. Gronemeyer H, Gustafsson JA, Laudet V. Principles for modulation of the nuclear receptor superfamily. Nat Rev Drug Discov. 2004; 3(11):950-64.

131. Qiang L, Wang L, Kon N, Zhao W, Lee S, Zhang Y, et al. Brown remodeling of white adipose tissue by SirT1-dependent deacetylation of Ppargamma. Cell. 2012; 150(3):620-32.

132. Hu E, Kim JB, Sarraf $P$, Spiegelman BM. Inhibition of adipogenesis through MAP kinase-mediated phosphorylation of PPARgamma. Science. 1996; 274(5295):2100-3.

133. Camp HS, Tafuri SR. Regulation of peroxisome proliferator-activated receptor gamma activity by mitogen-activated protein kinase. J Biol Chem. 1997; 272(16):10811-6.

134. lankova I, Petersen RK, Annicotte JS, Chavey C, Hansen JB, Kratchmarova I, et al. Peroxisome proliferator-activated receptor gamma recruits the positive transcription elongation factor $b$ complex to activate transcription and promote adipogenesis. Mol Endocrinol. 2006; 20(7):1494-505.

135. Compe E, Drané $P$, Laurent $C$, Diderich K, Braun C, Hoeijmakers JH, et al. Dysregulation of the peroxisome proliferator-activated receptor target genes by XPD mutations. Mol Cell Biol. 2005; 25(14):6065-76.

136. Houtkooper RH, Auwerx J. Obesity: New life for antidiabetic drugs. Nature. 2010; 466(7305):443-4.

137. Rull A, Geeraert B, Aragonès G, Beltrán-Debón R, Rodríguez-Gallego E, GarcíaHeredia $A$, et al. Rosiglitazone and fenofibrate exacerbate liver steatosis in a mouse model of obesity and hyperlipidemia. A transcriptomic and metabolomic study. J Proteome Res. 2014; 13(3):1731-43.

138. da Costa Leite LF, Veras Mourão RH, de Lima M do C, Galdino SL, Hernandes MZ, de Assis Rocha Neves F, et al. Synthesis, biological evaluation and molecular modeling studies of arylidene-thiazolidinediones with potential hypoglycemic and hypolipidemic activities. Eur J Med Chem. 2007; 42(10):126371.

139. Soares E Silva AK, de Oliveira Cipriano Torres D, Santos Rocha SW, dos Santos Gomes FO, dos Santos Silva B, Donato MA, et al. Effect of new thiazolidine derivatives LPSF/GQ-02 and LPSF/GQ-16 on atherosclerotic lesions in LDL receptor-deficient mice (LDLR(-/-)). Cardiovasc Pathol. 2013; 22(1):81-90.

140. Soares e Silva AK, de Oliveira Cipriano Torres D, dos Santos Gomes FO, dos Santos Silva B, Lima Ribeiro E, Costa Oliveira A, et al. LPSF/GQ-02 inhibits the development of hepatic steatosis and inflammation in a mouse model of nonalcoholic fatty liver disease (NAFLD). PloS One. 2015; 10(4):e0123787. 
141. Green $H$, Meuth $M$. An established pre-adipose cell line and its differentiation in culture. Cell. 1974; 3(2):127-33.

142. Student AK, Hsu RY, Lane MD. Induction of fatty acid synthetase synthesis in differentiating 3T3-L1 preadipocytes. J Biol Chem. 1980; 255(10):4745-50.

143. Mueller E, Drori S, Aiyer A, Yie J, Sarraf P, Chen H, et al. Genetic analysis of adipogenesis through peroxisome proliferator-activated receptor gamma isoforms. J Biol Chem. 2002; 277(44):41925-30.

144. Otto TC, Lane MD. Adipose development: from stem cell to adipocyte. Crit Rev Biochem Mol Biol. 2005; 40(4):229-42.

145. Ntambi JM, Young-Cheul K. Adipocyte differentiation and gene expression. J Nutr. 2000; 130(12):3122S-3126S.

146. Ministério da ciência, tecnologia e inovação; Conselho nacional de controle de experimentação animal (CONCEA). Diretriz brasileira para o cuidado e a utilização de animais para fins científicos e didáticos - DBCA. Brasília, DF: O Ministério; 2013.

147. Ministério da ciência, tecnologia e inovação; Conselho nacional de controle de experimentação animal (CONCEA). Diretrizes da prática de eutanásia do CONCEA. Brasília, DF: O Ministério; 2013.

148. Conselho Federal de Medicina Veterinária. Guia brasileiro de boas práticas em eutanásia em animais - Conceitos e procedimentos recomendados. Brasília, DF: Comissão de ética, bioética e bem-estar animal/CFMV; 2012.

149. Brasil. Lei no 12.305, de 2 de gosto de 2010. Institui a Política Nacional de Resíduos Sólidos; altera a Lei no 9.605, de 12 de fevereiro de 1998; e dá outras providências. Diário Oficial da União 3 agosto 2010; Seção 1.

150. Harms MJ, Ishibashi J, Wang W, Lim HW, Goyama S, Sato T, et al. Prdm16 is required for the maintenance of brown adipocyte identity and function in adult mice. Cell Metab. 2014; 19(4):593-604.

151. Folch J, Lees M, Sloane Stanley GH. A simple method for the isolation and purification of total lipides from animal tissues. J Biol Chem. 1957; 226(1):497509.

152. Pantoja C, Huff JT, Yamamoto KR. Glucocorticoid signaling defines a novel commitment state during adipogenesis in vitro. Mol Biol Cell. 2008; 19(10):403241

153. Jiang G, Dallas-Yang Q, Li Z, Szalkowski D, Liu F, Shen X, et al. Potentiation of insulin signaling in tissues of Zucker obese rats after acute and long-term treatment with PPARgamma agonists. Diabetes. 2002; 51(8):2412-9.

154. Picard F, Auwerx J. PPAR (gamma) and glucose homeostasis. Annu Rev Nutr. 2002; 22:167-97.

155. Semple RK, Chatterjee VK, O'Rahilly S. PPAR gamma and human metabolic disease. J Clin Invest. 2006; 116(3):581-9;

156. Nesto RW, Bell D, Bonow RO, Fonseca V, Grundy SM, Horton ES, et al. Thiazolidinedione use, fluid retention, and congestive heart failure: a consensus statement from the American Heart Association and American Diabetes Association. Diabetes Care. 2004; 27(1):256-63. 
157. Rubenstrunk A, Hanf R, Hum DW, Fruchart JC, Staels B. Safety issues and prospects for future generations of PPAR modulators. Biochim Biophys Acta. 2007; 1771(8):1065-81.

158. Watkins PB, Whitcomb RW. Hepatic dysfunction associated with troglitazone. N Engl J Med. 1998; 338(13):916-7.

159. Woodcock J, Sharfstein JM, Hamburg M. Regulatory action on rosiglitazone by the U.S. Food and Drug Administration. N Engl J Med. 2010; 363(16):1489-91.

160. Chaudhary S, Dube A, Kothari V, Sachan N, Upasani CD. NS-1: a novel partial peroxisome proliferator-activated receptor gamma agonist to improve insulin sensitivity and metabolic profile. Eur J Pharmacol. 2012; 684(1-3):154-60.

161. Surwit RS, Kuhn CM, Cochrane C, McCubbin JA, Feinglos MN. Diet-induced type II diabetes in C57BL/6J mice. Diabetes. 1988; 37(9):1163-7.

162. Surwit RS, Feinglos MN, Rodin J, Sutherland A, Petro AE, Opara EC, et al. Differential effects of fat and sucrose on the development of obesity and diabetes in C57BL/6J and A/J mice. Metabolism. 1995; 44(5):645-51.

163. Sociedade Brasileira de Diabetes. Diretrizes da Sociedade Brasileira de Diabetes 2013-2014. São Paulo: AC Farmacêutica; 2014.

164. Spinelli MO, de Godoy CMSC, da Motta MC, da Cruz RJ, Junqueira MS, Bortolatto J. Perfil bioquímico dos animais de laboratório do biotério da Faculdade de Medicina da USP. RESBCAL. 2012; 1(1):76-81.

165. Feldmann HM, Golozoubova V, Cannon B, Nedergaard J. UCP1 ablation induces obesity and abolishes diet-induced thermogenesis in mice exempt from thermal stress by living at thermoneutrality. Cell Metab. 2009; 9(2):203-9.

166. Fukui Y, Masui S, Osada S, Umesono K, Motojima K. A new thiazolidinedione, NC-2100, which is a weak PPAR-gamma activator, exhibits potent antidiabetic effects and induces uncoupling protein 1 in white adipose tissue of KKAy obese mice. Diabetes. 2000; 49(5):759-67.

167. Festuccia WT, Oztezcan S, Laplante M, Berthiaume M, Michel C, Dohgu S, et al. Peroxisome proliferator-activated receptor-gamma-mediated positive energy balance in the rat is associated with reduced sympathetic drive to adipose tissues and thyroid status. Endocrinology. 2008; 149(5):2121-30. 
ANEXO I

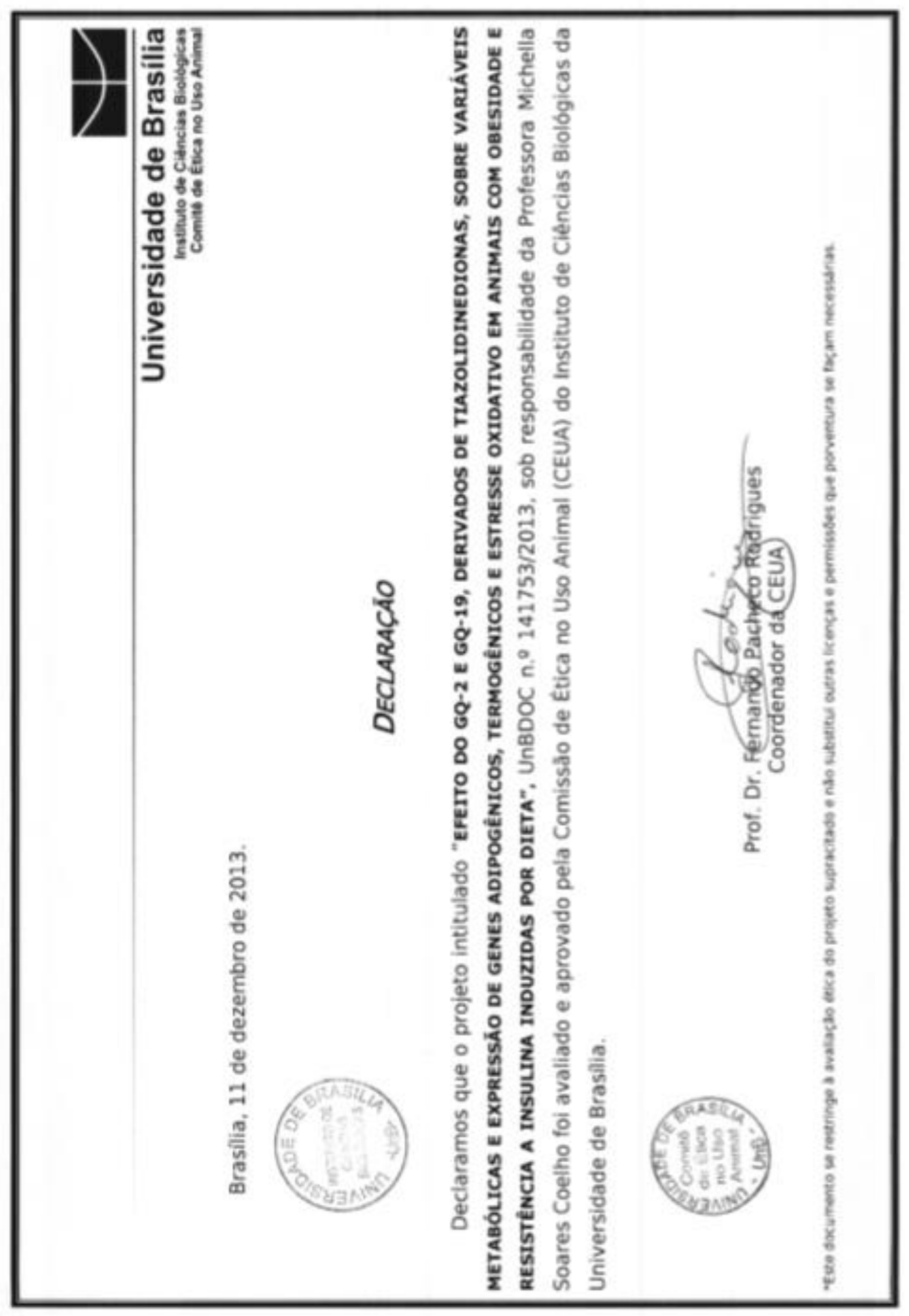




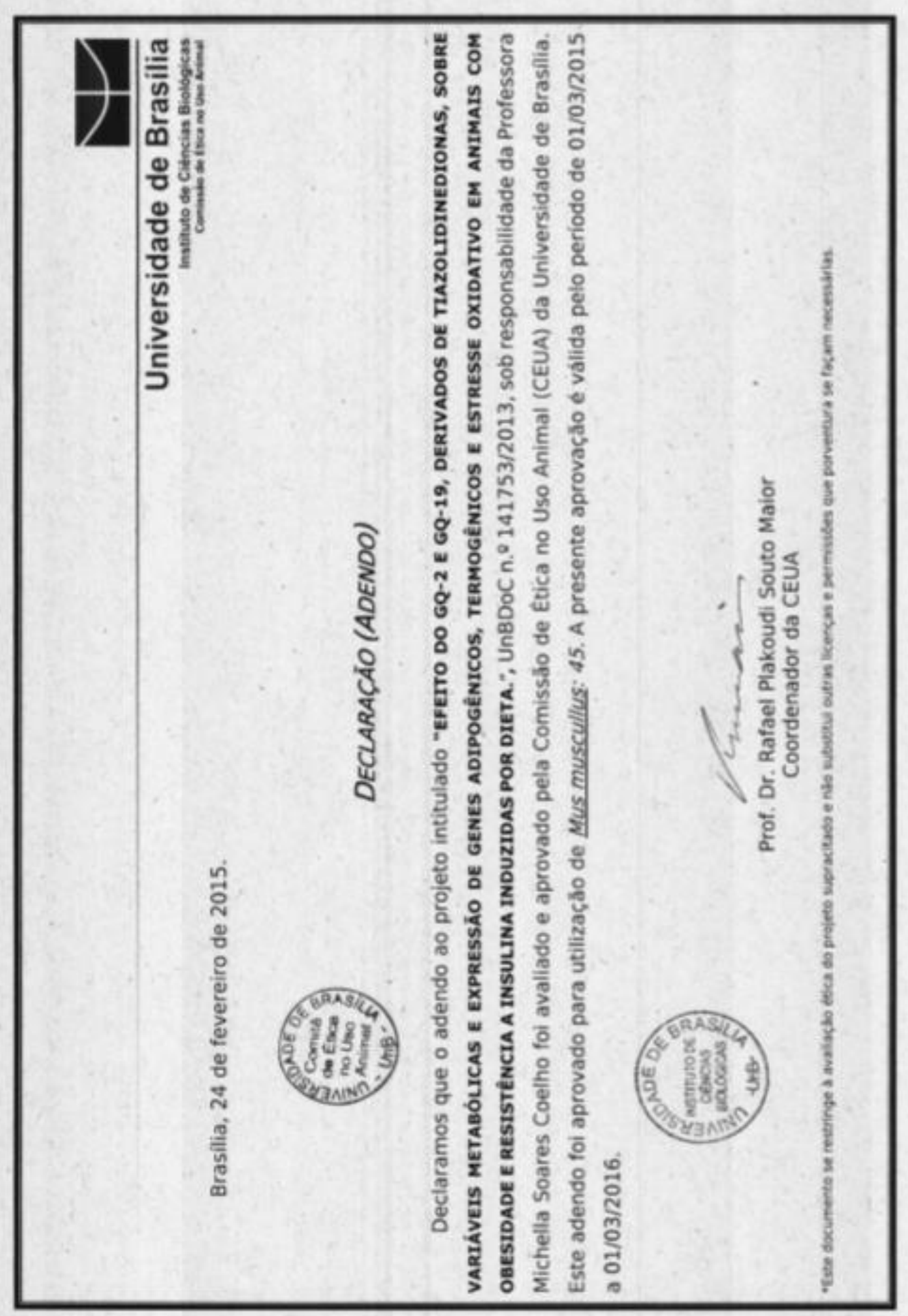

